\title{
Causaliteit in het Belgisch strafrecht
}

\author{
Joëlle Rozie en Thierry Vansweevelt*
}

'Felix qui potuit rerum cognoscere causas'

\section{Inleiding, methodologie en afbakening}

I. Causaliteit houdt de mensheid al eeuwenlang bezig. Zo hield Aristoteles in de vierde eeuw v.Chr. reeds voor dat niets niet iets kan teweegbrengen. Als er iets is dan moet dit iets wel door iets anders komen en derhalve door dit andere iets zijn veroorzaakt. Deze redenering zou ad infinitum kunnen worden doorgetrokken tot men botst op de zogenoemde 'eerste onbewogen beweger' die het universum in beweging houdt zonder zelf door iets of iemand anders te worden bewogen. ${ }^{2}$ Dit uitgangspunt kwam weer in de schijnwerpers te staan met de ontdekking in de kwantumfysica (meer bepaald van de Nobelprijswinnaars Englert en Higgs) dat zonder dat ene elementair deeltje dat alle andere deeltjes massa geeft, niets anders kan bestaan.

2. De vraag naar causaliteit is zonder twijfel een uitdagende vraag, ook in het recht. Wanneer men spreekt over causaliteit in het recht, kijkt men bijna reflexmatig naar het buitencontractueel aansprakelijkheidsrecht. In die rechtstak wordt de problematiek van het causaal verband als een van de moeilijkst te doorgronden vraagstukken gecatalogeerd. ${ }^{3}$ In het strafrecht werd aan dit onderwerp tot nu toe veel minder aandacht besteed, maar ook daar wordt de problematiek als complex en zelfs obscuur afgeschilderd. 4

Strafrecht en buitencontractueel aansprakelijkheidsrecht: geen jurist die het nochtans in zijn hoofd zou durven halen beide rechtsdisciplines over dezelfde kam te scheren. In de literatuur wordt zelfs in de verf gezet dat 'het wellicht onbegonnen werk is alle verschilpunten tussen de strafrechtelijke en civielrechtelijke aansprakelijkheid op te sommen'. ${ }^{5}$ Het uitgangspunt kan dan misschien wel zijn dat het buitencontractueel

* Prof. dr. J. Rozie is hoogleraar Strafrecht bij de Onderzoeksgroep Rechtshandhaving aan de Universiteit Antwerpen. Prof. dr. T. Vansweevelt is hoogleraar Buitencontractueel aansprakelijkheidsrecht bij de Onderzoeksgroep Persoon \& Vermogen aan de Universiteit Antwerpen.

I 'Gelukkig is hij die de oorzaak van dingen kon herkennen' (naar een citaat van Vergilius, ook geciteerd in o.m. de stripverhalen 'Asterix op Corsica' en 'De beproeving van Obelix').

2 Het filosofisch concept van de 'onbewogen beweger' wordt als volgt verwoord: 'ex nihilo nihil fit'.

3 H. DE PAGE, Traité élémentaire de droit civil belge, II, Brussel, Bruylant, I964, 96I: 'Le problème de la relation causale constitue une des plus grandes difficultés de notre matière'.

4 R. VAN ROYE, Manuel de la partie civile, Brussel, Bruylant, Librairie Judiciaire Polydore Pée, I945, 39: 'La notion de cause est l'une des plus complexes et des plus obscures du droit'; C. HENNAU-HUBLET, L'activité médicale et le droit pénal, Brussel, Bruylant, I987, I82.

5 T. VANSWEEVELT en B. WEYTS, Handboek Buitencontractueel Aansprakelijkheidsrecht, Antwerpen, Intersentia, 2009, 3I. 
aansprakelijkheidsrecht na een lange periode gedomineerd te zijn geweest door het strafrecht, een steeds groter wordende autonomie heeft verworven; toch blijkt in de realiteit dat de grenslijn heel dun kan zijn. Tussen beide rechtstakken blijven nog heel wat aanrakingspunten bestaan. ${ }^{6}$ Sterker nog, volgens bepaalde auteurs is hier zelfs sprake van een omgekeerde beïnvloeding: het buitencontractueel aansprakelijkheidsrecht heeft het causaliteitsbegrip geïmporteerd in het strafrecht en heeft er het strafrecht a.h.w. mee gecontamineerd. ${ }^{7}$

3. Is hier inderdaad sprake van contaminatie, en zo ja, is dat goed of zouden beide rechtstakken op basis van hun autonomie beter hun eigen causaliteitsbegrippen hanteren?

Een eigen invulling van de term 'causaliteit' is best mogelijk, nu dit begrip in geen enkele wetsbepaling wordt omschreven. Het buitencontractueel aansprakelijkheidsrecht kent de basisbepaling van artikel $\mathrm{I}_{3} 82 \mathrm{BW}$ waarin het vereiste van het causaal verband prijkt: men is slechts aansprakelijk als zijn fout aan een derde schade heeft veroorzaakt. Maar het begrip zelf wordt niet gedefinieerd. In het strafrecht komt het begrip causaal verband zelfs helemaal niet voor, tenzij in het raam van de internering. Bij nader inzien is het materieel strafrecht niettemin toch ook doorspekt van rechtsfiguren waarbij de causaliteit een cruciale rol speelt. De stelling dat 'het vereiste oorzakelijk verband een veel grotere rol speelt in het burgerlijk aansprakelijkheidsrecht dan in het strafrecht' ${ }^{\text {' }}$ of 'dat het causaliteitsprobleem in het strafrecht geen bestaansreden heeft' ${ }^{\prime} \mathrm{kan}$ dan ook geenszins worden bijgevallen, zoals zal blijken uit deze bijdrage.

Ook de autonome positie van het strafrecht brengt met zich mee dat het strafrecht een eigen invulling kan geven aan bepaalde concepten. Men spreekt dan van de conceptuele autonomie van het strafrecht. Het beginsel van de conceptuele autonomie van het strafrecht impliceert dat het strafrecht zelf zijn eigen begrippen bepaalt zonder gebonden te zijn door andere rechtstakken. Volgens de heersende rechtspraak van het Hof van Cassatie ${ }^{\text {Io }}$ mag de strafrechter oordelen aan de hand van begrippen die aan andere rechtstakken zijn ontleend zonder gehouden te zijn aan die begrippen de specifieke betekenis toe te kennen die zij in die andere rechtstakken hebben en zonder dit begrip te hanteren zoals dit in die andere rechtstakken wordt geregeld. Nochtans kan worden vastgesteld dat de civielrechtelijke causaliteitstheorieën vaak als aanknopingspunt dienen wanneer het veroorzaken van een gevolg een constitutief bestanddeel vormt van het misdrijf dan wel een verzwarende

6 Zie over deze raakpunten, zoals het keuzerecht tussen burgerlijke rechter en strafrechter, de schorsing van het burgerlijk proces tijdens de strafprocedure, het gezag van het strafrechtelijk gewijsde en de verjaring: T. VANSWEEVELT en B. WEYTS, Handboek Buitencontractueel Aansprakelijkheidsrecht, Antwerpen, Intersentia, 2009, 38-82.

7 A. DELANNAY, 'Les homicides et lésions corporelles volontaires', in Les infractions. Volume 2. Les infractions contre les personnes, Brussel, Larcier, 20I0, I55, nr. 63.

8 M. VAN QUICKENBORNE, Oorzakelijk verband tussen onrechtmatige daad en schade, Mechelen, Kluwer, 2007, I.

9 D. VAN ECK, Causaliteit en aansprakelijkheid voor gevolgen in het strafrecht, I, Nijmegen, Dekker \& Van de Vegt, I947, 3.

Io Cass. 28 juni I948, Arr.Cass. I948, 356; Cass. 5 februari I985, Arr.Cass. I984-85, 763 ; Cass. 27 maart I995, Arr.Cass. I995, 35I; Cass. 25 februari I997, Arr.Cass. I997, I07; Zie ook R. LEGROS, 'Essai sur l'autonomie du droit pénal', Rev.dr.pén. 1956-57, 150. 
omstandigheid uitmaakt. ${ }^{\text {II }}$ Soms wordt dan weer geschermd met de primauteit van het strafrecht onder het mom van billijkheidsoverwegingen. Er is evenwel geen rode draad te ontwaren. Het is bedroevend hoe weinig de reeds gepubliceerde Belgische penale literatuur zich inlaat over de al dan niet aanwezige interactie tussen het strafrecht en het buitencontractueel aansprakelijkheidsrecht. ${ }^{\mathrm{I} 2}$ De doctrine waarbij de causaliteitsproblematiek centraal staat, moet voornamelijk worden gezocht in de sfeer van het buitencontractueel aansprakelijkheidsrecht, ${ }^{13}$ maar ook hier wordt de link met het strafrecht ofwel niet ofwel eerder stiefmoederlijk behandeld.

4. Deze bijdrage beoogt deze lacune op te vullen. De onderzoeksvraag bij uitstek is dan ook na te gaan in hoeverre de autonomie van het strafrecht nog overeind blijft zodra een causaliteitsvraagstuk in het vizier komt. Telkens zal worden nagegaan in welke mate de civielrechtelijke invulling van het causaliteitsbegrip weerklank vindt in het strafrecht. De toetsing zal op gefragmenteerde wijze dienen te geschieden gezien de aanwezigheid van verschillende burgerrechtelijke causaliteitstheorieën. Er bestaat dus geen universeel civielrechtelijk causaliteitsbegrip, laat staan dat er een gemeenschappelijk rechtstakoverschrijdend causaliteitsbegrip voorhanden is. Causaliteit is de dag van vandaag geen tastbaar juridisch gegeven. De vaststelling ervan vloeit voort uit een geestelijk juridisch avontuur teneinde verschillende omstandigheden uiteindelijk op een of andere wijze aan elkaar te relateren. ${ }^{\mathrm{I}}$ De uitdaging is er dan ook in gelegen te streven naar een meer coherente benadering van het causaliteitsvraagstuk en dit over de rechtstakken heen, in het bijzonder wat het strafrecht en het buitencontractueel aansprakelijkheidsrecht betreft. Deze doelstelling kan alleen maar worden bereikt wanneer de toetsing consequent wordt doorgevoerd. Het dient evenwel te worden benadrukt dat er geen voorafname zal plaatsvinden om een tunnelvisie te vermijden. Uit de analyse zal immers moeten blijken of alle causaliteitsvormen in het strafrecht wel ontleend kunnen worden aan het civiele recht dan wel of er correcties dienen te worden aangebracht ten behoeve van de autonomie van het strafrecht.

II L. DUPONT en R. VERSTRAETEN, Handboek Belgisch Strafrecht, Acco, Leuven, I990, I9o; R. VERSTRAETEN en F. VERBRUGGEN, Strafrecht en strafprocesrecht voor bachelors, Antwerpen, Maklu, 20I3, 46 e.v.

I2 Met uitzondering van L. DUPONT en R. VERSTRAETEN, Handboek Belgisch Strafrecht, Acco, Leuven, I990, I89-I97 (doch enkel m.b.t. de gevolgmisdrijven).

I3 Zie o.m. M. VAN QUICKENBORNE, De oorzakelijkheid in het recht van de burgerlijke aansprakelijkheid. Een methodologisch en positief-rechtelijke analyse, Brussel, Elsevier-Sequoia, I972, 564p.; M. VAN QUICKENBORNE, Oorzakelijk verband tussen onrechtmatige daad en schade, Mechelen, Kluwer, 2007, I6op.; J-L FAGNART, La causalité, Waterloo, Kluwer, 2009, 366p.; H. BOCKEN, 'Het causaal verband tussen misdrijf en schade', in A. DE NAUW, J. D'HAENENS en M. STORME (eds.), Actuele Problemen van Strafrecht, XIVe Postuniversitaire Cyclus Willy Delva, Antwerpen, Kluwer, I988, 439-470; H. BOCKEN, 'Enkele hoofdthema's van de causaliteitsproblematiek', TBBR I988, 268300; H. BOCKEN, 'Actuele problemen inzake het oorzakelijk verband', in M. STORME (ed.), Recht halen uit aansprakelijkheid. XIXde Postuniversitaire Cyclus Willy Delva, Gent, Mys\&Breesch, I993, 8I-I23; H. BOCKEN en I. BOONE, 'Causaliteit in het Belgisch recht. Preadvies voor de Vereniging voor de Vergelijkende Studie van het recht van België en Nederland', TPR 2002, I625-1736.

I4 Zie ook R. SAVATIER, Traité de la responsabilité civile en droit français, Parijs, LGDJ, I95I, II, 6: 'La causalité n'est pas quelque chose qui se voit et se touche, mais un rapport déduit des circonstances de fait, par une opération de l'esprit.' 
Om de vergelijking tussen het strafrecht en het buitencontractueel aansprakelijkheidsrecht adequaat te kunnen doorvoeren, dient er vooreerst vertrokken te worden van een accurate gemeenschappelijke werkdefinitie die dienstig kan zijn voor de beide rechtstakken.

Causaliteit impliceert het met elkaar laten relateren van verschillende in een norm omschreven omstandigheden. Het leerstuk van de strafrechtelijke/civielrechtelijke causaliteit zal dus moeten aangeven welke omstandigheden als aanknopingspunt kunnen dienen voor de strafrechtelijke/civielrechtelijke verantwoordelijkheid of aansprakelijkheid. Gemakshalve zal in deze bijdrage consequent gesproken worden van strafrechtelijke en civielrechtelijke aansprakelijkheid.

Vanuit een helikoptervisie en vertrekkende vanuit de drie sleutelbegrippen van het materieel strafrecht zal worden nagegaan waar de causaliteit een rol kan spelen. Het materieel strafrecht kan worden gedefinieerd als het geheel van rechtsregels die bepaalde gedragingen strafbaar stellen en sancties bepalen die op de daders toepasselijk zijn. Het fenomeen causaliteit zal dan ook worden geanalyseerd vanuit drie sleutelbegrippen: misdrijf, dader en sanctie. Er zullen evenwel keuzes moeten worden gemaakt waardoor niet alle strafrechtelijke topics aan bod zullen kunnen komen binnen het bestek van deze bijdrage.

5. Zoals hierboven reeds werd aangekaart, komen de belangrijkste causaliteitsproblemen aan bod op het niveau van de delictsomschrijving. Bij gevolgmisdrijven zal het bewijs moeten worden geleverd van een causaal verband tussen de menselijke gedraging en het feit voortvloeiende uit deze gedraging, alvorens er sprake kan zijn van strafbaarheid of van strafverzwaring. Op misdrijfniveau zal eveneens de problematiek van de strafbare poging te berde worden gebracht. Een strafbare poging impliceert hoe dan ook dat er een begin van uitvoering moet zijn. Bij de invulling van het vereiste van het begin van uitvoering zit ontegensprekelijk een causaliteitsvraagstuk. Thans wordt immers veelal in de Belgische jurisprudentie aangenomen dat zodra de handeling of de gedraging geen twijfel laat bestaan over de bedoeling van de dader en zij moet leiden tot de voltrekking van het misdrijf, er sprake is van begin van uitvoering.

Een tweede niveau waarin het causaal verband speelt, is dat van het daderschap. De invulling van het daderschap omvat in eerste instantie het leggen van een causaal verband tussen het misdrijf en één of meerdere personen. Toerekenen omvat inderdaad een juridische beoordeling die het mogelijk moet maken een rechtssubject als dader of deelnemer te verbinden met één of meerdere strafbare feiten. ${ }^{15}$ Het zou ons te ver leiden al de aspecten gerelateerd aan de toerekening te analyseren. Wat bv. buiten het bestek van deze bijdrage valt, is de problematiek van het moreel bestanddeel alsook de toerekening in het raam van de strafrechtelijke verantwoordelijkheid

I5 Zie R. LEGROS, 'L'imputabilité pénale et entreprise économique', Rev.dr.pén. I968-69, 372: 'Imputer un fait à quelqu'un c'est affirmer que c'est bien cette personne qui en est l'auteur'; E. SIKKEMA en P. WAETERINCKX, De strafrechtelijke verantwoordelijkheid van leidinggevenden in economische context, Nijmegen, Wolf Legal Publishers, 20I0, II6; P. WAETERINCKX, De strafrechtelijke verantwoordelijkheid van de rechtspersoon en zijn leidinggevenden, Antwerpen, Intersentia, 20II, 4. 
van de rechtspersoon. ${ }^{16}$ Op het niveau van de dader zal daarom enerzijds worden gefocust op de strafbare deelneming. Anderzijds zal het lot van de geestesgestoorde delinquent worden geanalyseerd nu dit in grote mate gedetermineerd wordt door de causaliteitsvraag of de betrokkene leed aan een geestesstoornis die zijn oordeelsvermogen of de controle over zijn daden heeft tenietgedaan of ernstig heeft aangetast.

Op een derde niveau, dat van de sanctie, kan het causaal verband ook een belangrijke rol spelen. Eén straf springt in het vizier, m.n. de bijzondere verbeurdverklaring. De verbeurdverklaring is immers een rechterlijke beslissing die het eigendomsrecht over zaken die te maken hebben met het plegen van het misdrijf aan de veroordeelde ontneemt en toekent aan de Staat, de burgerlijke partij of de belanghebbende derde. De verbondenheid of m.a.w. het causaal verband tussen het goed en het misdrijflijkt dus cruciaal te zijn.

Dit brengt ons m.a.w. tot de volgende deelhoofdstukken:

- Enkele causaliteitstheorieën in het buitencontractueel aansprakelijkheidsrecht

- Causaliteit in het strafrecht: het misdrijf

- Gedragsmisdrijven

- Gevolgmisdrijven

- Strafbare poging

- Causaliteit in het strafrecht: de dader

- Strafbare deelneming

- Geestesgestoorde delinquent

- Causaliteit in het strafrecht: de sanctie

- Bijzondere verbeurdverklaring

- Besluit

\section{Enkele causaliteitstheorieën in het buitencontractueel aansprakelijkheidsrecht}

6. Om het causaal verband vast te stellen tussen een fout (of een andere aansprakelijkheidsgrond) en de schade wordt in de meeste Europese rechtsstelsels een

I6 Zie hierover o.m. V. FRANSSEN, 'Daderschap en toerekening bij rechtspersonen', NC 2009, 227248; F. ROGGEN, 'Participation et imputabilité: l'application de ces principes à l'épreuve de la responsabilité pénale des personnes morales', in P. MANDOUX en O. KLEES (eds.), Actualités de droit pénal et de procédure pénale, Jeune Barreau de Bruxelles, 200I, 5 e.v.; P. WAETERINCKX, De strafrechtelijke verantwoordelijkheid van de rechtspersoon en zijn leidinggevenden, Antwerpen, Intersentia, 20II, I85p. 
onderscheid gemaakt tussen de feitelijke en de juridische oorzaken van een schadegeval. ${ }^{17}$ In een eerste stap wordt nagegaan welke de feitelijke oorzaken waren van het schadegeval. Onderzocht wordt of zonder dat bepaald feit of dat bepaald gedrag de schade zich ook zou hebben voorgedaan. Dit wordt ook wel de conditio sine qua nontest genoemd: is het feit of het gedrag een noodzakelijke voorwaarde geweest voor die schade? Deze test wordt in het Anglo-Amerikaanse recht de 'but for test' genoemd die bestaat uit de vraag: "would the loss have been sustained but for the relevant act or omission of the defendant? ${ }^{38}$ Wanneer het antwoord op deze conditio sine qua non-test negatief is, kan de aangesprokene normaal niet aansprakelijk worden gesteld, wegens gebrek aan causaal verband.

Is het antwoord positief, dan volgt in de meeste landen, maar niet in België, een tweede fase, die van de juridische causaliteit. In de meeste systemen worden niet alle feitelijke oorzaken als gelijkwaardig beschouwd. Een billijkheidscorrectie is nodig om de anders almaar uitdijende kring van gevolgen van een gedraging in te perken. ${ }^{19}$ Tussen de feitelijke oorzaken wordt aldus een selectie gemaakt. Verschillende criteria worden daarbij gehanteerd om de oorzaken die een voldoende nauwe band vertonen met het schadegeval, te selecteren. De toepassing van die criteria heeft geleid tot verschillende causaliteitstheorieën. Enkele relevante theorieën worden hier kort toegelicht, met hun voor- en nadelen. ${ }^{20}$

\section{De equivalentietheorie}

7. In de eerste plaats wordt aandacht besteed aan de equivalentietheorie die in België door de heersende rechtspraak en rechtsleer wordt gehuldigd. Volgens deze theorie komen alle fouten die een noodzakelijke voorwaarde zijn voor het schadegeval als oorzaak in aanmerking. ${ }^{2 \mathrm{I}} \mathrm{Zij}$ zijn alle equivalent of gelijkwaardig. De vraag naar het causaal verband gebeurt in deze theorie in één stap en niet, zoals in andere landen, in twee fases. De feitelijke en juridische causaliteit vallen in feite samen in het Belgische recht. ${ }^{22}$

Het uitgangspunt van deze theorie is de vaststelling dat doorgaans verschillende voorwaarden noodzakelijk zijn voor de totstandkoming van een schadegeval. Geen van deze voorwaarden is op zichzelf voldoende om de schade tot stand te brengen, maar ze zijn wel alle noodzakelijk, nu zonder een van deze voorwaarden de schade

I7 Zie o.m. W. VAN GERVEN en S. COVEMAEKER, Verbintenissenrecht, Leuven, Acco, 20o6, 4I7; H. BOCKEN en I. BOONE, 'Causaliteit in het Belgische recht', TPR 2002, I628, nr. 3.

i8 D. DOBBS, The law of torts, St.Paul, West Group, 2000, 409; S. DEAKIN, A. JOHNSTON en B. MARKESINIS, Markesinis and Deakin's Tort law, Oxford, Clarendon Press, 2008, 244.

I9 J.H. NIEUWENHUIS, 'Eurocausaliteit', TPR 2002, I700-I70I, nrs. 6-7.

20 Dit overzicht is gebaseerd op T. VANSWEEVELT en B. WEYTS, Handboek Buitencontractueel Aansprakelijkheidsrecht, Antwerpen, Intersentia, 2009, 764 e.v., nrs. I223 e.v.

2I H. DE PAGE, Traité élémentaire de droit civil belge, II, Brussel, Bruylant, I964, nr. 958.

22 H. BOCKEN en I. BOONE, 'Causaliteit in het Belgische recht', TPR 2002, p. I634, nr. 7; in dezelfde zin: J.L. FAGNART, La causalité,Waterloo, Kluwer, 2009, nr. Io8. 
zich niet op die wijze zou hebben voorgedaan. Nu al deze voorwaarden noodzakelijk zijn voor het schadegeval, worden zij geacht een gelijke of equivalente causale rol te hebben gespeeld, vandaar de naam equivalentietheorie. ${ }^{23}$

Nadat alle noodzakelijke voorwaarden werden vastgesteld, wordt in de equivalentietheorie dus geen verdere selectie meer doorgevoerd tussen oorzaken die rechtstreeks of onrechtstreeks hebben bijgedragen tot de schade. Elke voorwaarde wordt geacht de gevolgen, d.i. de schade, op een gelijkwaardige wijze te hebben veroorzaakt. Elke schakel van de causaliteitsketting of elke persoon wiens gedrag of hoedanigheid heeft bijgedragen tot het schadegeval kan voor de gehele schade worden aangesproken, afgezien van verdere verdeling tussen de verschillende schadeverwekkers onderling. Volgens de equivalentietheorie kan een schadeverwekker ook aansprakelijk zijn voor abnormale, niet-noodzakelijke of onvoorzienbare gevolgen ${ }^{24}$ van zijn fout of andere aansprakelijkheidsgrond waarvoor hij instaat.

Een fraai voorbeeld is de zaak Courtellemont over een autobestuurster, Courtellemont, die in Parijs werd aangereden door een onvoorzichtige Belgische vrachtwagenchauffeur en vervolgens in een ziekenhuis werd opgenomen. Tijdens een operatie kreeg zij hiv-besmet bloed toegediend. Omdat begin jaren tachtig er nog geen hiv-test beschikbaar was om het donorbloed te screenen, werd niet het bloedtransfusiecentrum of het ziekenhuis aansprakelijk gesteld, maar wel de vrachtwagenchauffeur, nu zonder zijn fout er geen aanrijding was geweest en evenmin een operatie met toediening van hiv-besmet bloed. ${ }^{25}$

8. De beoordeling van de equivalentietheorie kan slechts genuanceerd zijn. Het is zonder twijfel de meest ruime causaliteitstheorie. Bovendien is het ook de meest slachtoffervriendelijke leer. ${ }^{26}$ De benadeelde kan elke persoon voor de gehele schade aanspreken die rechtstreeks of onrechtstreeks een noodzakelijke bijdrage tot het schadegeval heeft geleverd. De equivalentietheorie is inderdaad de enige leer die rekening houdt met elke fout zonder welke de schade zich niet zou hebben voorgedaan. In die zin is het ook een objectieve theorie, die de subjectieve interpretatie van een feitenrechter voorkomt en dus de rechtszekerheid dient. ${ }^{27}$ Verder wordt gewezen op haar eenvoudige toepassing: het volstaat vast te stellen dat zonder deze factor de schade zich niet zou hebben voorgedaan. ${ }^{28}$

23 R.O. DALCQ, Traité, II, nr. 2355.

24 Cass. 17 april I975, Arr.Cass. I975, 908 en Pas. I975, I, 820.

25 Cour d'appel Paris 7 juli i989, De Verz. I990, I38, noot F. DE LY en Gaz.Pal. I992, 752, met concl. PICHOT.

26 H. COUSY en A. VANDERSPIKKEN, 'Causation under Belgian law', in Unification of tort law:causation, J. SPIER (ed.), Den Haag, Kluwer law international, 2000, 24; H. BOCKEN, 'Toerekening van aansprakelijkheid op grond van de equivalentieleer', in Buitencontractuele aansprakelijkheid, Reeks Recht en onderneming, Brugge, die Keure, 2007, 244.

27 J.L. FAGNART, La causalité, Waterloo, Kluwer, 2009, nr. 48.

28 H., L., J. MAZEAUD en A.TUNC, Traité théorique et pratique de la responsabilité civile délictuelle et contractuelle, II, I970, nr. I442. 
Anderzijds ontsnapt de equivalentietheorie niet aan kritiek. Volgens sommigen is een consequente toepassing van deze leer onmogelijk, omdat zij de aansprakelijkheid al te ver uitbreidt naar het aantal actoren maar ook in de tijd. ${ }^{29}$ De eenvoud van deze causaliteitstheorie is eerder schijn dan werkelijkheid. $3^{\circ}$ De abstracte speculaties over wat er zou gebeurd zijn zonder de fout, zijn onvermijdelijk in deze theorie en maken daar juist de zwakte van uit. ${ }^{\text {I }}$ Ten slotte wegen sommige oorzaken nu eenmaal meer door in de totstandkoming van het schadegeval en is het dus onbillijk om die een gelijke waarde toe te kennen. ${ }^{32}$ Deze theorie geeft de rechter aldus weinig beoordelingsvrijheid.

Niettegenstaande deze scherpe kritiek, zijn er toch landen zoals België waar de equivalentietheorie wordt toegepast. Om de kritiek te omzeilen dat deze theorie leidt tot al te verregaande en in de tijd teruggaande aansprakelijkheden met een eindeloos aantal verhaalsvorderingen, aanvaardt de Belgische rechtspraak uitzonderingen en temperingen op de equivalentietheorie. ${ }^{33}$ Een punt van kritiek dat hierop dan weer kan worden geleverd is dat een dergelijke principiële toepassing met uitzonderingen, tot rechtsonzekerheid en incoherentie leidt.

\section{De adequatietheorie}

9. Onder meer in Duitsland, vroeger in Nederland, maar ook in vele andere landen, zoals Oostenrijk en Zwitserland, wordt de zogenoemde adequatietheorie in varianten toegepast. Volgens die theorie is een gevolg toerekenbaar wanneer die in adequaat verband staat met de fout. De schade moet m.a.w. het normale of redelijkerwijze te verwachten gevolg zijn van de fout of de tot aansprakelijkheid aanleiding gevende factor. ${ }^{34}$

In de in de vorige paragraaf vermelde zaak Courtellemont zou op basis van de adequatietheorie en in het licht van de toen bestaande medische kennis, wellicht geen aansprakelijkheid van de vrachtwagenbestuurder worden vastgesteld. Het toedienen van besmet bloed kon toen niet als een te verwachten gevolg van een verkeersongeval worden beschouwd.

29 R. PIRSON en A. DE VILLE, Traité de la responsabilité civile extra-contractuelle, II, Brussel, Bruylant,I935, 30; I. DURANT, 'La causalité, simple trait d'union ou véritable variable d'ajustement?', in Droit des obligations: développements récents et pistes nouvelles, P. WERY (ed.), CUP volume 96, Luik, Anthémis,2007, 43-45; zie ook H. BOCKEN, 'Enkele hoofdthema's van de causaliteitsproblematiek', TBBR I988, 270; zie voor een kritiek hierop: J.L. FAGNART, La causalité, Waterloo, Kluwer, 2009, nrs. 53-56.

30 H., L., J. MAZEAUD en A. TUNC, Traité théorique et pratique de la responsabilité civile délictuelle et contractuelle, II, I970, nr. I442, noot 2.

3 I J.L. FAGNART, 'Chronique de jurisprudence - La responsabilité aquilienne (I955-I967)', JT I969, 276.

32 Cf. R.O. DALCQ, Traité de la responsabilité civile, in Les Novelles, Droit civil, II, Brussel, Larcier, I962, nr. 2357.

33 Cf. voor een overzicht: T. VANSWEEVELT en B. WEYTS, Handboek Buitencontractueel Aansprakelijkheidsrecht, Antwerpen, Intersentia, 2009, 865 e.v., nrs. I353 e.v.

34 Cf. J. VAN SCHELLEN, Juridische causaliteit, Deventer, Kluwer, I972, 87 e.v. 
Interessant ter vergelijking met de equivalentietheorie is ook een ouder arrest van de Nederlandse Hoge Raad. In dit zogenoemd Zolderruitarrest ${ }^{35}$ zoekt een bakker 's nachts iets op zolder. Wanneer zijn niet goed werkende elektrische zaklantaarn het begeeft, loopt hij in het donker tegen de zolderruit, die breekt en naar beneden stort op een toevallige voorbijganger die daardoor zijn oog verliest. Aansprakelijkheid werd op basis van de adequatietheorie afgewezen, nu deze schade niet te voorzien was, maar eerder resulteerde uit een toevallige samenloop van omstandigheden.

Io. Een voordeel van de adequatietheorie is dat zij een criterium aanbiedt om een selectie te maken tussen de verschillende mogelijke oorzaken van een schadegeval. Ver verwijderde oorzaken kunnen buiten beschouwing worden gelaten. ${ }^{6}$ Bovendien dient met deze theorie een toevallige samenloop van omstandigheden niet tot aansprakelijkheid te leiden. Dit criterium is gebaseerd op de redelijkheid en laat de rechter dus een zekere beoordelingsvrijheid.

Anderzijds wordt de adequatietheorie verweten te vaag te zijn wat leidt tot rechtsonzekerheid en soms tot willekeur. ${ }^{37}$ In de praktijk is het geen sinecure uit te maken wat wel en wat niet als een voorzienbaar gevolg van een fout kan worden bestempeld. Vanuit het oogpunt van de benadeelde kan deze theorie ook onbillijk overkomen, omdat die niet zal begrijpen waarom hij wel vergoeding krijgt voor de normale gevolgen van de fout van de schadeverwekker, maar niet voor de abnormale gevolgen ervan. ${ }^{38}$ Bovendien wordt het gebruik van één criterium als te beperkend ervaren en moet de rechter de ruimte worden geboden om met verschillende relevante omstandigheden rekening te houden opdat redelijke resultaten zouden worden bereikt. ${ }^{39}$ Ook wordt de adequatietheorie verweten het probleem te verplaatsen van het causaliteitsterrein naar dat van de fout. Nagaan wat als voorzienbare gevolgen of schade moet worden beschouwd, leidt al snel tot een beoordeling van het gedrag van de schadeverwekker. Had hij de schade moeten voorzien en heeft hij de nodige maatre-

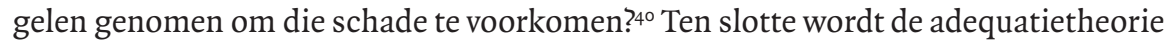
bekritiseerd, nu men niet inziet hoe het criterium van de voorzienbaarheid van de schade kan worden toegepast bij objectieve aansprakelijkheden. ${ }^{4 \mathrm{I}}$

35 HR I5 november I934, NJ I935, 42I, noot P.S.; zie voor de verschillende commentaren op dit arrest: J. VAN SCHELLEN, Juridische causaliteit, Deventer, Kluwer, 1972, 94-96.

36 M. VAN QUICKENBORNE, Oorzakelijk verband tussen onrechtmatige daad en schade, Mechelen, Kluwer, 2007, 22.

37 B. WEYTS, De fout van het slachtoffer in het buitencontractueel aansprakelijkheidsrecht, Antwerpen, Intersentia, 2004, nr. 304.

38 R. PIRSON en A. DE VILLE, Traité de la responsabilité civile extra-contractuelle, II, Brussel, Bruylant, I935, 35 .

39 J.H. NIEUWENHUIS, 'Eurocausaliteit. Agenda voor het Europese debat over toerekening van schade', TPR 2002, I70I, nr. 7; A.S. HARTKAMP en C.H. SIEBURGH, Mr. C. Assers Handleiding tot de beoefening van het Nederlands Burgerlijk recht, 6-II, De verbintenis in het algemeen, Deventer, Kluwer, 2009, nr. 57.

40 H., L., J. MAZEAUD en A. TUNC, Traité théorique et pratique de la responsabilité civile délictuelle et contractuelle, II, I970, nr. I442.

4I J.L. FAGNART, La causalité, Waterloo, Kluwer, 2009, nr. 65. 


\section{De theorie van de efficiënte oorzaak}

II. De theorie van de efficiënte oorzaak maakt een onderscheid tussen de voorwaarden en de oorzaken van de schade. Van elke voorwaarde van een schadegeval gaat een zekere mate van energie uit. Dat maakt die voorwaarden nog niet tot oorzaak van de schade. De oorzaak is die voorwaarde waarvan de meeste energie of kracht uitgaat. Dit wordt dan de efficiënte oorzaak genoemd. ${ }^{42}$

Ook in de Belgische rechtspraak zijn voorbeelden of varianten van deze theorie terug te vinden. ${ }^{33}$ Vaak wordt dan verwezen naar de 'cause génératrice' of 'beslissende oorzaak'. Pirson en De Villé hebben deze theorie verdedigd omdat die, anders dan de equivalentieleer, in hun ogen veel soepeler is, de rechter meer beoordelingsvrijheid geeft, en de aansprakelijkheid binnen redelijke grenzen houdt. ${ }^{4}$

Een befaamd cassatiearrest dat tot uiteenlopende interpretatie aanleiding heeft gegeven, is het butagasarrest. Bij het laden van verschillende butagastankwagens deed zich een ontploffing voor. Drie personen worden aangesproken: de aangestelde die instond voor de lading, maar zich niet op de reglementaire plaats bevond; de tankwagenbestuurder die, zoals de laadmeester, de tankwagen liet laden zonder aankoppeling van de afvoerleiding en die tijdens het laden niet ter plaatse was gebleven; een andere tankwagenbestuurder die zijn motor had aangezet, terwijl hij zijn beurt afwachtte. Ofschoon de eerste twee factoren hadden bijgedragen tot het schadegeval werden ze niet als fouten aangemerkt. Het hof van beroep te Brussel besliste dat de laatstgenoemde factor, het starten van de motor, een fout was en tevens 'de beslissende oorzaak' van het schadegeval. Het Hof van Cassatie verwierp de cassatievoorziening en oordeelde dat het begrip 'beslissende oorzaak' in het bestreden arrest betekende dat binnen alle voorwaarden van het schadegeval, het de enige is die een noodzakelijk causaal verband met de schade vertoonde, m.a.w. dat zonder de fout de schade zich niet zou hebben voorgedaan, zoals ze zich in concreto had gerealiseerd. 45

Een deel van de rechtsleer zag in dit cassatiearrest een afstand van de equivalentietheorie en een toenadering naar de theorie van de efficiënte oorzaak. ${ }^{4}$ Wellicht is dit een te overhaaste conclusie geweest, zeker nu het cassatiearrest de klassieke definitie weergeeft van oorzaak in de equivalentieleer. Het Hof van Cassatie lijkt o.i.

42 A.M. HONORE, 'Causation and remoteness of damage', in International Encyclopedia of Comparative law, XI, Torts, p. 38 , nr. 67.

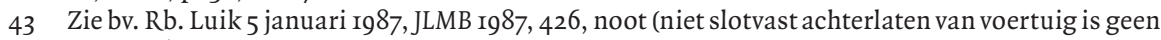
'cause décisive' van diefstal en verkeersongeval).

44 R. PIRSON en A. DE VILLE, Traité de la responsabilité civile extra-contractuelle, II, Brussel, Bruylant, I935, 37-39.

45 Cass. I8 november ig63, Pas. I964, I, 288, RGAR i964, nr. 7336, noot J. SCORIELS en RCJB I965, 24, noot R. BUTZLER.

46 R. BUTZLER, 'La théorie de l'équivalence des conditions est-elle périmée?', (noot onder Cass. I8 november i963), RCJB I965, 30, 34 en 37. 
met dit arrest zeker de equivalentietheorie niet te hebben opgegeven. ${ }^{47}$ Wel biedt het de feitenrechters de mogelijkheid binnen de verschillende factoren die tot het schadegeval hebben bijgedragen, sommige ervan als fout te bestempelen en sommige als niet-foutief, waardoor de equivalentietheorie op een bepaalde manier wel kan worden omzeild.

I2. De voornaamste kritiek op de theorie van de efficiënte oorzaak is dat zij in een aantal categorieën van schadegevallen geen aansprakelijkheid oplevert, terwijl de rechtvaardigheid dit wel vereist. Wanneer de fout bestaat uit het nalaten een bepaalde handeling te stellen of informatie te verstrekken waardoor een schadegeval had kunnen worden voorkomen, levert dit geen aansprakelijkheid op. Immers, van een nalaten gaat geen energie of kracht uit en bijgevolg komt dit niet als oorzaak in aanmerking. In dezelfde zin is deze causaliteitstheorie problematisch wanneer er sprake is van pluraliteit van oorzaken en de ene oorzaak geen en de andere wel een kracht heeft uitgeoefend. Honoré geeft volgend voorbeeld: als A zijn wagen 's nachts zorgvuldig bestuurt, maar tegen B's auto inrijdt die niet verlicht was, heeft A de mechanische kracht uitgeoefend, en niet B, terwijl B eerder aansprakelijk gesteld zou moeten worden..$^{8}$ Ten slotte wordt gevreesd dat met deze theorie de rechter geneigd zal zijn de efficiëntie van de fout op subjectieve wijze te beoordelen door na te gaan welke schade zij kon veroorzaken vanuit het gezichtspunt van de schadeverwekker waardoor fout en causaal verband opnieuw met elkaar worden verward. ${ }^{49}$

\section{De theorie van de rechtstreekse en onmiddellijke gevolgen}

I3. Om de causaliteitsketen en de aansprakelijkheid binnen redelijke perken te houden, wordt ook voorgesteld de aansprakelijkheid van de schadeverwekker te beperken tot de rechtstreekse en/of onmiddellijke gevolgen van de fout of de tot aansprakelijkheid aanleiding gevende factor. Deze leer wordt bijvoorbeeld in Frankrijk gehuldigd..$^{\circ}$

Voorstanders van deze theorie kunnen zich beroepen op artikel II5I BW waarin wordt voorgeschreven dat de schuldenaar in geval van wanprestatie, zelfs bij een opzettelijke fout, enkel gehouden is tot de onmiddellijke en rechtstreekse gevolgen van zijn wanprestatie.

Ofschoon artikel II5I BW betrekking heeft op het causaal verband in de contractuele aansprakelijkheid, ziet een deel van de Franse rechtsleer en rechtspraak de regel

47 In die zin ook: H. VANDENBERGHE, M. VAN QUICKENBORNE en P. HAMELINK, 'Overzicht van rechtspraak. Aansprakelijkheid uit onrechtmatige daad (1964-1978)', TPR I980, I352.

48 A.M. HONORE, 'Causation and remoteness of damage' in International Encyclopedia of Comparative law, XI, Torts, 39, nr. 67.

49 R.O. DALCQ, Traité de la responsabilité civile, in Les Novelles, Droit civil, II, Brussel, Larcier, I962, nr. 2379.

50 P. LE TOURNEAU, Droit de la responsabilité et des contrats, Dalloz, 2008, nr. 1776. 
als een algemeen beginsel van causaliteit voor het gehele aansprakelijkheidsrecht. ${ }^{\mathrm{I}}$ Ook een deel van de Belgische rechtsleer ${ }^{52}$ en rechtspraak ${ }^{53}$ tonen zich voorstander van deze causaliteitstheorie.

I4. Het doel van de theorie van de rechtstreekse gevolgen bestaat erin de te vergoeden gevolgen van een fout binnen de perken te houden. Hoe verder de schade verwijderd is van de fout, hoe moeilijker de schade aan die fout toerekenbaar wordt ${ }^{54}$ en hoe onzekerder het causaal verband wordt. Omdat de aansprakelijkheid ergens moet stoppen, wordt onrechtstreekse schade niet vergoed.

Anderzijds wordt gestipuleerd dat deze theorie vooral wil benadrukken dat er zekerheid moet zijn over het bestaan van het causaal verband tussen fout en schade. Zodra die zekerheid bestaat, moet de schade worden vergoed, ook al is die schade verder af gelegen, zowel in de tijd als in de ruimte. ${ }^{55}$

De kritiek op deze theorie is tweevoudig. In de eerste plaats is rechtsonzekerheid inherent aan de invulling van begrippen. Het is niet steeds voorspelbaar wat juist als rechtstreeks en onmiddellijk gevolg moet worden begrepen. In de Franse rechtspraak en rechtsleer bestaan daar tegenstrijdigheden over. ${ }^{56}$ Op de tweede plaats kan een strikte toepassing van deze causaliteitstheorie ook onrechtvaardige gevolgen hebben, in het bijzonder wanneer in het algemeen vergoeding zou worden geweigerd voor schade ontstaan door handelingen of gebeurtenissen die volgen op het gedrag van de aangesproken partij. ${ }^{57}$

I5. Een variante op deze theorie is de leer van de 'proximate cause' zoals die in het Anglo-Amerikaanse recht wordt toegepast. De zuivere interpretatie van deze leer die enkel de oorzaak die in de tijd het dichtst staat bij het schadegeval in aanmerking neemt, komt weinig voor. Wel doet de Anglo-Amerikaanse rechtspraak regelmatig een beroep op de term 'proximate cause', naast termen als 'direct', 'foreseeable' of 'remote'. Deze termen dienen om het causaal verband tussen een fout en de schade al dan niet vast te stellen of beter nog om de aansprakelijkheid van de schadeverwekker

5I H., L., J. MAZEAUD en A. TUNC, Traité théorique et pratique de la responsabilité civile délictuelle et contractuelle, II, I970, nr. I670; P. LE TOURNEAU, Droit de la responsabilité et des contrats, Dalloz, 2008, nr. 1776 .

52 Cf. R.O. DALCQ, Traité de la responsabilité civile, in Les Novelles, Droit civil, II, Brussel, Larcier, I962, nr. 2472 en 2475 die indirecte schade beschouwt als schade zonder een voldoende zeker causaal verband met de schade.

53 Zie bv. Arbh. Brussel 26 oktober 1972, RW I973-74, 6I2 (ongeval moet het rechtstreeks gevolg zijn van een eerder arbeidsongeval).

54 L. JOSSERAND, Cours de droit civil positiffrançais, II, Parijs, Sirey, I933, nr. 449 ('le moment arrive assez vite où on doit s'arrêter dans cette recherché des conséquences dommageables dont la cause première devient impossible à discerner avec certitude').

55 H., L., J. MAZEAUD en A. TUNC, Traité théorique et pratique de la responsabilité civile délictuelle et contractuelle, II, I970, nr. I677.

56 Zie P. LE TOURNEAU, Droit de la responsabilité et des contrats, Dalloz, 2008, nr. I776 met voorbeelden.

57 Zie A.M. HONORE, 'Causation and remoteness of damage' in International Encyclopedia of Comparative law, XI, Torts, p. 42, nr. 72. 
binnen redelijke grenzen te houden, hierbij vooral rekening houdend met de schade die door de fout voorzienbaar was. ${ }^{58}$

De leer van de proximate cause of laatste oorzaak wordt vooral bij pluraliteit van oorzaken onbillijk en zelfs gevaarlijk genoemd. Een consequente toepassing zou inderdaad tot gevolg kunnen hebben dat de minst schuldige de gehele schade moet dragen, enkel omdat zijn fout de laatste oorzaak was. ${ }^{59}$

I6. De theorie van de rechtstreekse en onmiddellijke gevolgen of van de laatste oorzaak is duidelijk strijdig met de equivalentietheorie en vindt daarom geen genade in de ogen van het Hof van Cassatie. De feiten in deze zaak waren als volgt: in het raam van het opsporen van ondergrondse nutsleidingen, had een aannemer voorputten gemaakt op grond van plannen die hem door de telefoonmaatschappij ter beschikking waren gesteld. Die plannen waren niet correct en drie in een betonnen kanalisatie gelegen telefoonkabels werden doorboord. Het hof van beroep te Antwerpen besliste dat het causaal verband tussen de fout van de telefoonmaatschappij onjuiste plannen te hebben overgemaakt inzake de ligging van de nutsleidingen en de kabelschade, doorbroken werd door de chronologisch laatste fout. Dit was in casu de fout van de aannemer die bij het graven van een voorput voor het opsporen van nutsleidingen op een betonnen kanalisatie was gestoten en die i.p.v. manueel te ontmantelen of inlichtingen in te winnen zoals een zorgvuldig aannemer zou hebben gedaan, het beton en ook de kabels had doorboord. Dit arrest wordt logischerwijze op grond van de in België heersende equivalentietheorie vernietigd, nu uit de enkele omstandigheid dat een fout nadien gevolgd wordt door de fout van een andere partij, niet kan worden afgeleid dat er geen causaal verband bestaat tussen de eerste fout en de schade. ${ }^{60}$

\section{De theorie van de toerekening naar redelijkheid}

17. In Nederland werd tot in de jaren zeventig de adequatietheorie toegepast. Op die theorie kwam evenwel van langsom meer kritiek: deze theorie werd verweten te weinig houvast te bieden en soms tot onredelijke resultaten te leiden. Als gevolg van die kritiek is men overgestapt van de adequatietheorie naar de leer van de toere-

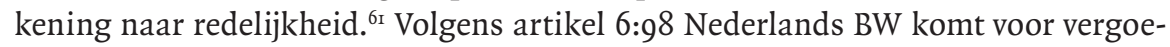
ding slechts in aanmerking schade die in zodanig verband staat met de gebeurtenis waarop de aansprakelijkheid berust, dat ze hem, mede gezien de aard van de aan-

58 D. DOBBS, The law of torts, West-Academic Publishing, 2000, 409; zie ook S. DEAKIN, A. JOHNSTON en B. MARKESINIS, Markesinis and Deakin's Tort law, Clarendon Press, 2008, 244245 .

59 J. VAN SCHELLEN, Juridische causaliteit, Deventer, Kluwer, I972, 85-86.

60 Cass. I2 januari 2007, Pas. 2007, I, 62, TBH 2007, 786, noot C. VAN SCHOUBROECK en NjW 2007, 845, noot GJ; zie hierover ook J.L. FAGNART, La causalité, Waterloo, Kluwer, 2009, nr. 60.

6 I A.S. HARTKAMP en C.H. SIEBURGH, Mr. C. Assers Handleiding tot de beoefening van het Nederlands Burgerlijk recht, 6-II, De verbintenis in het algemeen, Deventer, Kluwer, 2009, nr. 57; HR 20 maart I970, NJ I970, 25I, noot GJS. 
sprakelijkheid en van de schade, als een gevolg van deze gebeurtenis kan worden toegerekend. In navolging van het burgerlijk recht wordt het toerekeningscriterium ook toegepast in het Nederlandse strafrecht. De rechter dient zich af te vragen of het redelijk is het ingetreden gevolg (het letsel) toe te rekenen aan het gedrag van de verdachte. $^{62}$

Het doel van deze leer is dat de rechter aan de hand van verschillende factoren nagaat of het redelijk is de schade aan iemand toe te rekenen. Zo wordt rekening gehouden met de in artikel 6:98 Nederlands BW vermelde factoren als de aard van de aansprakelijkheid (schuld- of risicoaansprakelijkheid bijvoorbeeld), en de aard van de schade (personenschade, zaakschade, bedrijfsschade en privéschade, ...). Daarnaast kunnen ook andere factoren relevant zijn, zoals de mate van schuld en de voorzienbaarheid van de schade.

De Nederlandse rechtspraak en rechtsleer hebben op basis van deze factoren zogenoemde deelregels voor toerekening opgesteld. Zo is in eerste instantie toerekening eerder gerechtvaardigd naarmate het gevolg naar ervaringsregels waarschijnlijker is, het gevolg minder ver verwijderd is van de onrechtmatige daad, de schuld groter is. Ook wordt rekening gehouden met het belang van het doel waarmee de norm in het leven is geroepen: zo bijvoorbeeld is er een ruimere toerekening als het de schending betreft van verkeers- en veiligheidsnormen die met het oog op voorkoming van ongevallen zijn opgesteld in geval van dood en letselschade. Letselschade komt ook eerder voor toerekening in aanmerking dan zaakschade, terwijl een ruimere toerekening ook gerechtvaardigd zou zijn bij foutaansprakelijkheid dan bij risicoaansprakelijkheid, bij bedrijfsmatig toegebrachte schade dan bij schade veroorzaakt door een beroepsbeoefenaar of een particulier, in geval van aanwezigheid van verzekeringen zowel bij de aansprakelijke persoon als bij de benadeelde, enz. ${ }^{63}$

Een variante op deze leer wordt in België verdedigd door Durant. ${ }^{64}$ Zij verdedigt een meer gediversifieerd causaliteitsbegrip dan de equivalentietheorie en meent dat het doel van het recht er niet in moet bestaan na te gaan of een factor een plaats heeft in de causaliteitsketen, maar wel of de schadelijke gevolgen van bepaald gedrag vanuit juridisch oogpunt aan een rechtssubject kunnen worden toegerekend. De door haar voorgestelde toerekeningscriteria zijn het doel van de geschonden norm en de voorzienbaarheid van de schade.

62 G. MEIJER, A. SEUTERS en R. TER HAAR, Leerstukken strafrecht, Deventer, Kluwer, 20Io, 270.

63 R. BOONEKAMP, $v^{\circ}$ Artikel 98 (6.1.9.4.), in Schadevergoeding, Deventer, Kluwer (uitgave 2009), 204, nr. 28; A.S. HARTKAMP en C.H. SIEBURGH, Mr. C. Assers Handleiding tot de beoefening van het Nederlands Burgerlijk recht, 6-II, De verbintenis in het algemeen, Deventer, Kluwer, 2009, nrs. 63 e.v.

64 I. DURANT, 'La causalité, simple trait d'union ou veritable variable d'ajustement', in P. WÉRY (ed.), Droit des obligations: développements récents et pistes nouvelles, CUP volume 96, Louvainla-Neuve, Anthémis, 2007, 7I-8I; zie voor kritiek op dit voorstel: J.L. FAGNART, La causalité, Waterloo, Kluwer, 2009, nr. 8o. 
I8. De kracht van deze toerekeningsleer wordt gezien in het verband tussen de aard van de aansprakelijkheid en van de schade: hierbij wordt een afweging en toerekening gemaakt rekening houdend met de soort gedraging en de soort schade. ${ }^{65}$ Hiermee verband houdend, is het voordeel van deze theorie ook de soepelheid waarmee een rechter omstandigheden in zijn oordeel kan betrekken om een redelijke oplossing uit te werken.

Daarentegen wordt de leer van de toerekening naar redelijkheid ook vaagheid en rechtsonzekerheid verweten, nu de beoordeling wordt vastgeknoopt aan alle mogelijke concrete omstandigheden. ${ }^{66}$ Wat juist verstaan moet worden onder een 'eerdere' of 'ruimere' toerekening is niet meteen duidelijk en biedt weinig houvast. Bovendien kunnen de deelregels ook in een verschillende richting wijzen: bijvoorbeeld letselschade bij risicoaansprakelijkheid. ${ }^{67}$ Ten slotte kan ook kritiek worden geuit op begrippen zoals 'voorzienbaarheid van de schade' en 'het doel van de norm'.

\section{Causaliteit in het strafrecht: het misdrijf}

\section{Gedragsmisdrijven}

19. Bij de zogenoemde gedragsmisdrijven ${ }^{68}$ of formele delictsomschrijvingen ${ }^{69}$ wordt bepaald onwenselijk gedrag bestraft. De enkele strafbare gedraging of de loutere schending van de norm volstaat voor de strafbaarheid, ongeacht de mogelijke gevolgen. Dit soort gedragsmisdrijven brengt geen causaliteitsproblemen met zich, nu enkel bepaald gedrag strafbaar wordt gesteld. De vraag of dit gedrag een bepaald gevolg heeft veroorzaakt, is irrelevant voor de strafbaarstelling. Voorbeelden van dit soort gedragsmisdrijven zijn diefstal (art. 46r Sw.) en dronkenschap aan het stuur (art. 34 Verkeerswet $^{70}$ ). Zo blijft diefstal strafbaar zelfs indien de eigenaar geen schade (meer) zou lijden, bv. omdat de dader na de voltooiing van het misdrijf de gestolen goederen aan de dader heeft gerestitueerd. Dronkenschap aan het stuur is op zich strafbaar, zelfs indien de dronkenschap geen slachtoffers heeft gemaakt.

20. Gedragsmisdrijven kunnen zowel een handeling als een onthouding strafbaar stellen. Diefstal en dronkenschap aan het stuur zijn voorbeelden van handelings- of

65 D. PEEPERKORN, 'Juridische causaliteit: redelijk en adequaat?', in Medische en juridische causaliteit, Lelystad, Koninklijke Vermande, I990, I8.

66 B. WEYTS, De fout van het slachtoffer in het buitencontractueel aansprakelijkheidsrecht, Antwerpen, Intersentia, 2004, nr. 548.

67 T. HARTLIEF, 'Schadevergoedingsrecht', in Verbintenissen uit de wet en schadevergoeding, Deventer, Kluwer, 2000, 206.

68 Wij geven de voorkeur aan het begrip gedragsmisdrijf, waar C. VAN DEN WYNGAERT, m.m.v. B. DE SMET en S. VANDROMME, Strafrecht en strafprocesrecht in hoofdlijnen, Antwerpen, Maklu, 20II, 226 spreekt over 'gedragingsmisdrijf'.

69 De term wordt gebruikt door: L. DUPONT en R. VERSTRAETEN, Handboek Belgisch Strafrecht, Acco, Leuven, I990, I9o.

70 Wet van I6 maart I968 betreffende de politie over het wegverkeer, BS 27 maart I968. 
commissiemisdrijven. Een voorbeeld van een verzuims- of omissiemisdrijf is het verzuim hulp te verlenen aan een persoon die in groot gevaar verkeert (art. 422bis Sw.). Het misdrijf schuldig verzuim vereist geen causaal verband tussen de nagelaten handeling en de doeltreffendheid ervan. Artikel 422bis Sw. bestraft de bewuste en opzettelijke onverschilligheid, de egoïstische weigering om hulp te bieden. Het hulpverzuim op zich volstaat om bestraft te worden, ongeacht de gevolgen of het bereikte resultaat. ${ }^{71}$

2I. We kunnen hier alvast wijzen op een belangrijk verschilpunt tussen het strafrecht en het aansprakelijkheidsrecht. Gedragsmisdrijven leiden tot strafbaarheid zonder bewijs van enig causaal verband.

Civielrechtelijke aansprakelijkheid bestaat niet zonder schade. Zonder schade geen civielrechtelijke aansprakelijkheid. Tussen een bepaalde aansprakelijkheidsfactor (fout, risico) en die schade moet altijd een causaal verband bestaan. In het buitencontractueel aansprakelijkheidsrecht bestaat dus geen aansprakelijkheid zonder schade en zonder causaal verband. Het buitencontractueel aansprakelijkheidsrecht kent m.a.w. geen equivalent van de strafrechtelijke gedragsmisdrijven.

\section{Gevolgmisdrijven}

22. De meeste misdrijven vereisen het veroorzaken van een bepaald gevolg, ofwel als constitutief bestanddeel ofwel als verzwarende omstandigheid. Hierbij kan gedacht worden aan het overlijden van een persoon (art. $4 \mathrm{I} 8 \mathrm{Sw}$.), het toebrengen van een letsel (art. 4I8 Sw.), aanranding van de eerbaarheid (art. 372 Sw.), ziekte of ongeschiktheid tot het verrichten van persoonlijke arbeid (art. 399 Sw.), enz. Men spreekt dan van gevolgmisdrijven, ${ }^{72}$ resultaatsmisdrijven, ${ }^{73}$ of van materiële delictsomschrijvingen. ${ }^{74}$ De meeste causaliteitsproblemen doen zich voor bij dit soort misdrijven, nu de causaliteit juist in het misdrijf is ingeschreven als constitutief bestanddeel of als verzwarende omstandigheid. Daarom wordt het causaal verband en in het bijzonder de equivalentietheorie in dit hoofdstuk het meest uitgewerkt.

7I Cass. 7 november 20I2, T.Gez.|Rev.dr.santé 20I2-20I3, 3IO, noot N. COLETTE-BASECQZ; dit arrest vernietigt Brussel 20 april 2012, T.Gez.|Rev.dr.santé 2012-2013, 305; A. DE NAUW, Inleiding tot het bijzonder strafrecht, Mechelen, Kluwer, 20I0, 234; J. ROZIE, 'Verloren tijd wordt nooit teruggevonden. Een analyse van het healingarrest', NC 20I3, 40I.

72 C. VAN DEN WYNGAERT, m.m.v. B. DE SMET en S. VANDROMME, Strafrecht en strafprocesrecht in hoofdlijnen, Antwerpen, Maklu, 20II, 297.

73 F. KUTY, Principes généraux du droit pénal belge. Tome II: l'infration pénale, Brussel, Larcier, 20Io, 76; N. COLETTE-BASECQZ en N. BLAISE, 'Responsablité civile et responsabilité pénale', Responsabilité. Traité théorique et pratique, Partie préliminaire, Livre 2, Waterloo, Kluwer, 20I2, 77, nr. I20.

74 L. DUPONT en R. VERSTRAETEN, Handboek Belgisch Strafrecht, Acco, Leuven, I99o, I9o. 


\section{I Het bewijs van het causaal verband en de bewijslast}

23. Hoewel gevolgmisdrijven zowel opzettelijke als onopzettelijke misdrijven kunnen zijn, doen er zich veel causaliteitsvraagstukken voor m.b.t. de onopzettelijke misdrijven waar het gebrek aan voorzorg of voorzichtigheid het moreel bestanddeel uitmaakt. Opdat een gebrek aan voorzorg of voorzichtigheid als oorzaak van de schade (lees: het door de strafbepaling beoogde gevolg, dit is de dood, het letsel, de ziekte, enz.) kan worden beschouwd, wordt, zoals gezegd, in België een beroep gedaan op de equivalentietheorie. Krachtens deze theorie moet elke fout zonder dewelke de schade zich niet zou hebben voorgedaan, zoals ze zich in concreto heeft gerealiseerd, als oorzaak van de schade worden beschouwd. ${ }^{75}$ Dit betekent dat elke fout die een noodzakelijke voorwaarde is voor de schade, tot aansprakelijkheid leidt. Er wordt geen selectie doorgevoerd tussen de fouten die een conditio sine qua nonverband met de schade (overlijden, het letsel) vertonen. Al deze fouten zijn allemaal oorzaak, ze zijn gelijkwaardig of 'equivalent'. ${ }^{6}$

Weliswaar kan de eis van het zogenoemd noodzakelijk karakter van de fout in het schadegebeuren tot verwarring aanleiding geven. Hiermee wordt niet bedoeld dat de schade een noodzakelijk gevolg moet zijn van het schadeverwekkend feit, of m.a.w. dat de schade die zich in een concreet geval voordeed zich noodzakelijk had moeten voordoen. Er wordt enkel mee bedoeld dat de fout een noodzakelijke voorwaarde moet zijn geweest voor het schadegebeuren.77

24. Om te kunnen bewijzen dat een fout een noodzakelijke voorwaarde is geweest voor de schade, wordt vaak nog een andere vraagstelling toegepast, namelijk de in Duitsland ontwikkelde theorie van het rechtmatig alternatief..$^{8}$ Volgens deze theorie moet het verhaal van het schadegeval worden gereconstrueerd waarbij de foutieve gedraging niet mag worden weggedacht, maar juist moet worden vervangen door een hypothetisch rechtmatig alternatief, in casu zorgvuldig gedrag. Indien schade zich ook zou hebben voorgedaan in de hypothese van het rechtmatig alternatief, dan blijkt daaruit dat de fout niet in causaal verband staat met de schade. ${ }^{79}$

75 Zie o.a.: Cass. 30 oktober I973, Arr.Cass. I974, 250 en Pas. I974, I, 239; Cass. 27 maart I980, Arr Cass. I979-80, 946 en Pas. I980, I, 93I.

76 R.O. DALCQ, Traité de la responsabilité civile, in Les Novelles, Droit civil, II, Brussel, Larcier, 1962 , nr. 2426; M. VAN QUICKENBORNE, De oorzakelijkheid in het recht van de burgerlijke aansprakelijkheid. Een methodologisch en positief-rechtelijke analyse, Brussel, Elsevier-Sequoia, I972, nrs. 34I e.v.

77 Cass. 22 december 1947, Arr.Verbr. I947, 425 en Pas. I947, I, 555; J. DABIN en A. LAGASSE, 'Examen de jurisprudence (I939-I948). La responsabilité délictuelle et quasi-délictuelle', RCJB I949, 87.

78 Zie uitvoerig over de verhouding tussen de equivalentietheorie en de theorie van het rechtmatig alternatief: DE RIEMAECKER, concl. bij Cass. 25 maart I997, Pas. I997, I, 406-4I6.

79 H. VANDENBERGHE, M. VAN QUICKENBORNE en P. HAMELINK, 'Overzicht van rechtspraak. Aansprakelijkheid uit onrechtmatige daad (1964-1978)', TPR I980, I353; H. BOCKEN, 'Actuele problemen inzake het oorzakelijk verband', Recht halen uit aansprakelijkheid, Gent, Mys \& Breesch, I993, 94 . 
In concreto moet aldus de onrechtmatige daad vervangen worden door een rechtmatige daad, een onrechtmatig nalaten door een rechtmatige handeling die door de schadeverwekker gesteld had moeten worden. ${ }^{80}$

25. Wel moet bij de toepassing van de theorie van het rechtmatig alternatief de reconstructie van het schadeverhaal gebeuren a.d.h.v. dezelfde concrete feiten.

Zo kan de afwezigheid van een causaal verband tussen een fout en de schade niet worden afgeleid uit de overweging dat die schade zich ook had kunnen voordoen in een hypothese die vreemd is aan de concrete omstandigheden van de zaak. ${ }^{8 \mathrm{r}}$

In een andere zaak betrof het een vrachtwagenchauffeur die een snelheidsovertreding had begaan door $90 \mathrm{~km}$ per uur te rijden met een lege vrachtwagen, terwijl hij met zijn vrachtwagen maximaal slechts $60 \mathrm{~km}$ per uur mag rijden, ongeacht of die vrachtwagen geladen is of niet. De correctionele rechtbank te Hasselt meent dat de snelheidsovertreding niet in causaal verband staat met de schade, nu een lege en tegen een snelheid van $90 \mathrm{~km}$ per uur rijdende vrachtwagen geen grotere schade veroorzaakt dan een geladen vrachtwagen die tegen $60 \mathrm{~km}$ per uur rijdt. Het Hof van Cassatie vernietigt het arrest, aangezien de door de rechters aangewende redenering van het rechtmatig alternatief slechts hanteerbaar is met inachtneming van dezelfde concrete omstandigheden als deze waarin het ongeval plaatshad. ${ }^{82}$

Omgekeerd komt het ook voor dat feitenrechters te veel eerbied vertonen voor de concrete omstandigheden en die omstandigheden of de daarbij begane fouten niet durven te vervangen door een rechtmatig alternatief, omdat zij vrezen zo de concrete omstandigheden te miskennen. Zo besliste de correctionele rechtbank te Bergen een autobestuurder voor een aanrijding van verschillende andere wagens

8o I. DURANT, 'À propos de ce lien qui doit unir la faute au dommage', in Droit de la responsabilité. Morceaux choisis, B. DUBUISSON en P. HENRI (ed.), CUP vol. 68, Brussel, Larcier, 2004, 22-23; J.L. FAGNART, La causalité, Waterloo, Kluwer, 2009, nrs. II8 e.v.; zie ook H. BOCKEN, 'Enkele hoofdthema's van de causaliteitsproblematiek', TBBR I988, 273 die erop wijst dat bij een nalaten de hypothetische reconstructie moeilijker is.

8I Cass. 8 oktober 1996, Arr.Cass. 1996, 88I en Pas. 1996, I, 943 (de afwezigheid van een causaal verband tussen een verkeersinbreuk, een witte ononderbroken lijn dwarsen, en het ongeval, wordt ten onrechte afgeleid uit de vaststelling dat het ongeval ook zou zijn gebeurd indien een andere bestuurder dezelfde verkeersinbreuk zou hebben gedaan, wat die in werkelijkheid niet had gedaan); Cass. 28 maart 200I, Arr.Cass. 200I, 5I4, Pas. 200I, I, 508 en TAVW 2002, 43, noot D. VAN TRIMPONT; in casu werd het zicht op de rijbaan beperkt door een onregelmatig geparkeerd voertuig waardoor een verkeersongeval zich voordeed; onjuist is de beslissing die het causaal verband ontkent tussen het onregelmatig geparkeerd voertuig en het verkeersongeval, door er simpel op te wijzen dat de zichtbaarheid eveneens beperkt was geweest indien er op dezelfde plek bijwoorbeeld een hut of een tent voor straatwerken had gestaan; Cass. I8 december 2008, A.R.C.07.0018.F (de afwezigheid van het causaal verband tussen de fout - onwettige bouwvergunningen voor het voetbalstadion te Charleroi te hebben afgeleverd die door de Raad van State nietig werden verklaard - en de schade, werd ten onrechte afgeleid uit het feit dat de benadeelden niet konden bewijzen dat de schade zich niet had kunnen voordoen indien wettige bouwvergunningen afgeleverd waren geweest).

82 Cass. I5 mei I990, Arr.Cass. I989-90, II80, Pas. I990, I, I054, Verkeersrecht, I990, 276 en RW I992-93, 758 (verkort). 
aansprakelijk te stellen. Hem werd een te hoog alcoholgehalte, een gebrek aan autoverzekering, inschrijving en technische controle van het voertuig verweten. Het causaal verband werd enkel afgeleid uit de bewering dat het verkeersongeval niet zou zijn gebeurd indien de bestuurder het voertuig niet op de openbare weg in het verkeer had gebracht. De feitenrechters weigerden te onderzoeken of de aanrijding zich op dezelfde wijze zou hebben voorgedaan, indien de bestuurder nuchter en zijn voertuig verzekerd, ingeschreven en regelmatig aan de technische controle onderworpen zou zijn geweest. Het Hof van Cassatie vernietigde het bestreden vonnis en verduidelijkte: 'Ofschoon de rechter bij de beoordeling van het oorzakelijk verband tussen de fout en de schade, de omstandigheden niet kan wijzigen waarin deze zich heeft voorgedaan, gebeurt dit wel onder voorbehoud dat de fout zelf wordt weggelaten. ${ }^{83}$ De feitenrechters konden zich aldus wel afvragen, zonder de concrete toedracht van het ongeval te wijzigen, of het ongeval zich niet op dezelfde wijze zou hebben voorgedaan indien de bestuurder nuchter en zijn voertuig tot het verkeer toegelaten zouden zijn geweest.

26. Bij toepassing van de theorie van het rechtmatig alternatief moet het causaal verband worden nagegaan tussen de concrete fout en de schade. ${ }^{8}$ Het is aldus de concrete fout die moet worden vervangen door een rechtmatig alternatief en niet het gehele gedrag dat als foutief kan overkomen. ${ }^{85}$

Een voorbeeld kan dit verduidelijken. Een persoon bestuurt een brommer of een wagen zonder daarvoor de vereiste leeftijd te hebben bereikt (of zonder in het bezit te zijn van een rijbewijs) en raakt betrokken in een verkeersongeval. Hij begaat dus zonder twijfel een fout. Op basis van de theorie van het rechtmatig alternatief moet het foutief aspect van dit gedrag vervangen worden door een rechtmatig alternatief. Aldus moet de feitenrechter zich afvragen of het ongeval zich op dezelfde wijze zou hebben voorgedaan indien de bestuurder meerderjarig (of in het bezit van een rijbewijs) zou zijn geweest. Indien het rijgedrag van de bestuurder zorgvuldig was, had de leeftijd (of het bezit van een rijbewijs) van de bestuurder blijkbaar geen invloed op de totstandkoming van het ongeval. Bijgevolg is er geen causaal verband tussen de concrete fout of tussen het foutief aspect van zijn gedrag en de schade. ${ }^{86}$

Omgekeerd, indien het schadegeval vermeden had kunnen worden indien de bestuurder meer behendigheid en rijvaardigheid had vertoond, waarover personen met een rijbewijs of ouder dan 18 jaar doorgaans beschikken, dan kan het rijden

83 Cass. 28 mei 2008, NjW 2009, 80, noot IB en RABG 2009, 655, noot N. VAN DE SYPE.

84 H. BOCKEN, 'Enkele hoofdthema's van de causaliteitsproblematiek', TBBR I988, 282; J.L. FAGNART, La causalité, Waterloo, Kluwer, 2009, nrs. I23-Izo.

85 Vgl. evenwel I. BOONE, 'Recente ontwikkelingen inzake causaliteit', in Aansprakelijkheidsrecht, Antwerpen, Maklu, 2004, 6I die dit een niet geheel orthodoxe redenering vindt, afwijkend van de equivalentietheorie, nu de concrete omstandigheden worden gewijzigd.

86 Cass. II september I984, Arr.Cass. I985, 59 en Pas. I985, I, 45 (bestuurder van motorfiets nog geen I8 jaar, begaat geen rijfout en aanwezigheid van duozitster heeft geen invloed gehad op bestuurbaarheid van voertuig); maar vgl. H. BOCKEN, 'Enkele hoofdthema's van de causaliteitsproblematiek', TBBR I988, 285 die het causaal verband lijkt te aanvaarden, omdat het de bedoeling van de wetgever is minderjarige bestuurders zonder meer uit het verkeer te weren. 
zonder rijbewijs of in de hoedanigheid van minderjarige wel als oorzakelijk met het ongeval worden beschouwd. ${ }^{87}$ Het causaal verband bestaat dan eerder tussen het gebrek aan rijervaring (weliswaar te wijten aan de jonge leeftijd) en het ongeval.

27. Het vermoeden van onschuld dat de beklaagde geniet, houdt in dat hij zijn onschuld niet moet bewijzen. Het is daarentegen de vervolgende partij die de bewijslast draagt van de ten laste gelegde feiten ${ }^{88}$ daarin begrepen het bewijs van het causaal verband. De vervolgende partij dient het causaal verband te bewijzen tussen de fout en de schade zoals die zich in concreto heeft gerealiseerd, ${ }^{89}$ of hij dient aan te tonen dat zonder de fout of een andere aansprakelijkheidsgrond de schade zich niet zou hebben voorgedaan, zoals ze zich in concreto heeft gemanifesteerd.

De vervolgende partij draagt ook het bewijsrisico: slaagt hij er niet in het bewijs van het causaal verband te leveren, dan kan de beklaagde niet worden veroordeeld.

28. Ook de tijd die is verlopen tussen de fout en de manifestatie van de schade, kan een hinderpaal vormen om het causaal verband te bewijzen.

Volgende zaak is daarvan een mooi voorbeeld. Drie jaar nadat hij was gebeten door een arrestant, stelt een politieagent vast dat hij besmet is door het hiv-virus. Het is dan evenwel onmogelijk na te gaan of de arrestant op het moment van het schadeverwekkend feit drager was van het virus. Daarnaast kan ook niet worden uitgesloten dat de politieagent door andere, professionele of privécontacten, besmet is geraakt..$^{\circ}$ Aldus kan de beklaagde wegens gebrek aan bewijs van het causaal verband niet worden veroordeeld.

In Nederland heeft zich een soortgelijke zaak voorgedaan. In de zogenoemde Groninger hiv-zaak organiseerden de verdachten, die drager waren van het hiv-virus en dit wisten, seksfeestjes voor homoseksuele mannen. Met het doel onder hivbesmette mannen onbekommerde seks te kunnen hebben, werden vier mannen tegen hun wil en zonder dit te weten geïnjecteerd met het hiv-geïnfecteerde bloed van een van de verdachten. Alle vier zijn zij enkele maanden later daadwerkelijk met hiv geïnfecteerd geraakt. Het hof te Leeuwarden ${ }^{91}$ veroordeelde de verdachten wegens zware mishandeling met voorbedachten rade. Wat het causaal verband betrof, oordeelde het hof dat niet ieder mogelijk alternatief, in casu een alternatieve

87 Corr. Bergen 22 maart I984, De Verz. I984, 549 (meenemen van passagierster op bromfiets beïnvloedt hanteerbaarheid van voertuig); Pol. Dinant 6 juli i995, T.Vred. 1996, 226 (meenemen van duozitster op bromfiets beïnvloedt hanteerbaarheid van voertuig en de aansprakelijkheid, evenals het niet dragen van een helm); H. VANDENBERGHE, M. VAN QUICKENBORNE en P. HAMELINK, 'Overzicht van rechtspraak. Aansprakelijkheid uit onrechtmatige daad (1964-1978)', TPR I980, I356.

88 R. VERSTRAETEN, Handboek strafuordering, Antwerpen, Maklu, 20I2, 967.

89 Cass. I3 oktober 1995, Arr.Cass. I995, 886 en Pas. I996, I, 917.

9o Brussel 9 juni I99I, RGAR I994, nr. I2.287; zie ook Corr. Brussel 26 maart I993, Rev.dr.pén.I993, 917 , noot.

9I Hof Leeuwarden 22 januari 20I0, NJ 20I0, nr. 90. 
besmettingsroute, behoeft te worden uitgesloten voordat tot een bewezenverklaring kan worden gekomen. Niet geheel uit te sluiten handelingen van derden staan het bewijs van het bestaan van het causale verband niet in de weg. De Hoge Raad92 vernietigde het arrest, omdat er weliswaar wel een vermoeden was dat de verdachten de besmetting hadden veroorzaakt, maar het hof niet heeft vastgesteld dat het hoogst onwaarschijnlijk was dat de hiv-besmetting van ieder van de slachtoffers het gevolg is van onbeschermde seks met een besmet persoon. Het verwijzingshof te Arnhem ${ }^{93}$ heeft de verdachten dan veroordeeld tot een gevangenisstraf van acht jaar wegens poging tot zware mishandeling.

Hoe dan ook, deze problematiek leidt ons naadloos naar de problematiek van de zekerheid van het causaal verband.

\subsection{Het causaal verband moet zeker zijn}

\subsubsection{Principes}

29. Er moet een voldoende graad van zekerheid bestaan over het causaal verband. De loutere mogelijkheid van een causaal verband volstaat niet. ${ }^{94}$ Heeft een fout slechts 'waarschijnlijk' ${ }^{95}$ of zelfs 'heel waarschijnlijk ${ }^{\prime 96}$ de schade veroorzaakt, of bestaat er 'onzekerheid'97 over het oorzakelijk verband tussen de fout en de schade, dan kan evenmin tot aansprakelijkheid worden besloten. Twijfel over het causaal verband kan ook niet leiden tot een gedeeltelijke aansprakelijkheid. ${ }^{8}$

Een treffend voorbeeld is de mogelijke strafrechtelijke aansprakelijkheid n.a.v. het neerstorten van een vliegtuig van het Jordaanse stuntteam (de Royal Jordanian Falcons) tijdens een luchtvaartshow op 26 juli 1997 op de luchthaven te Oostende. Het vliegtuig vatte vuur en kwam in aanraking met de hulppost van het Rode Kruis. Tien personen, onder wie de Jordaanse stuntpiloot, kwamen om en een aanzienlijk aantal personen raakte gewond. Twee leden van de organiserende vereniging, de vzw Aviation Promotion Team, de vluchtdirecteur en de veiligheidswaarnemer, werden strafrechtelijk vervolgd wegens onopzettelijke doding en onopzettelijke slagen en verwondingen. Beiden werden vrijgesproken. De vluchtdirecteur kon weliswaar wel fouten worden verweten, nl. het vluchtplan van de piloot niet vooraf te hebben opgevraagd en het niet volgen van de piloot tijdens zijn oefening (de 'display'), maar geen van die fouten stond in causaal verband met het ongeval. Het vluchtplan van de piloot en de door hem uitgevoerde bewegingen waren niet abnormaal of gevaarlijk,

92 HR 27 maart 20I2, NJ 20I2, nr. 30I, met concl. J. SILVIS en noot N. KEIJZER.

93 Hof Arnhem 29 november 20I2, NJ 20I3, nr. I8I.

94 Cass. 6 mei i996, Arr.Cass. I996, 399 en Pas. I996, I, 42I.

95 Cass 28 mei I95I, Arr.Verbr. I95I, 554 en Pas. I95I, I, 645; H.-D. BOSLY en C. DE VALKENEER, 'Les homicides et lésions corporelles non intentionnels', in Les infractions. Volume 2. Les infractions contre les personnes, Brussel, Larcier, 20I0, 498.

96 Cass. I7 september I98I, Arr.Cass. I98I-82, 95 en Pas. I982, I, 90.

97 Cass. 26 juni 2008, A.R.C.07.0272.N.

98 Cass. 6 oktober 1969, Arr.Cass. I970, I32 en Pas. I970, I, II5. 
enkel de uitvoering is foutief gebeurd. Bovendien zou volgens de deskundigen de vliegdirecteur, indien hij de bewegingen van de piloot had gevolgd, tussen de 8 à 20 seconden hebben gehad om te reageren tussen de foutieve beweging en de crash. Er was aldus onvoldoende tijd om nog nuttig te reageren. Het hof van beroep oordeelde dan ook dat de fouten niet in causaal verband stonden met het ongeval: 'Zonder deze fouten zou de schade onvermijdelijk ook ontstaan zijn op dezelfde wijze en met dezelfde gevolgen.' ${ }^{99}$ Op burgerlijk vlak werd het Vlaamse Gewest, als uitbater van de luchthaven van Oostende, objectief aansprakelijk gesteld. ${ }^{\text {10o }}$

\subsubsection{Verlies van een kans}

30. In verband met de zekerheid van het causaal verband is er wat betreft de verlies-van-een-kans-theorie een belangrijk onderscheid aan te stippen tussen het buitencontractueel aansprakelijkheidsrecht en het strafrecht. In het aansprakelijkheidsrecht wordt algemeen aanvaard dat het verlies van een kans om een bepaald voordeel te verwerven of een nadeel te vermijden, als een specifieke schadepost voor vergoeding in aanmerking komt. ${ }^{\text {Ior }}$ In het strafrecht daarentegen wordt het causaal verband tussen de fout en het kansverlies als onvoldoende zeker beschouwd voor een veroordeling wegens doding of slagen en verwondingen.

Een voorbeeld kan dit illustreren. Het hof van beroep te Brussel had een gynaecoloog veroordeeld omdat hij op een net bevallen patiënte, slachtoffer van een syncope (of aanval van bewustzijnsverlies) en van het daarmee gepaard gaande bloedverlies, niet de specifiek aangewezen behandeling, nl. fibrinolyse, had toegepast. Het gebrek aan voorzorg en vooruitzicht stond in een noodzakelijk oorzakelijk verband met het overlijden van de patiënte, aangezien de fout van de arts 90\% overlevingskansen van de patiënte had teniet gedaan, zo oordeelde het beroepshof. Het Hof van Cassatie vernietigde echter deze beslissing, omdat 'het arrest niet kon beslissen dat er tussen de fout en het overlijden een oorzakelijk verband bestond, zonder erop te wijzen dat onder de omstandigheden van de zaak de ondoeltreffendheid van de behandeling in Io\% der gevallen moest worden uitgesloten'. ${ }^{\text {102 }}$ Het bestaan van een causaal verband tussen de fout en het verlies van overlevingskansen, houdt

99 Gent 7 mei 2003, AR 9244I, onuitg.; zie ook over dit arrest: P. WAETERINCKX en K. DE SCHEPPER, 'Enkele bedenkingen bij de objectivering van de beoordeling van de strafrechtelijke verantwoordelijkheid in het ondernemingsstrafrecht', in M. FAURE en W. RAUWS (eds.), Recente ontwikkelingen in het arbeids-, economisch, straf- en familierecht. Huldeboek voor Mr. Jos Van Goethem, Antwerpen, Intersentia, 2009, I59.

Ioo Rb. Brugge I6 januari 2006, NjW 2006, I26, noot IB: de aansprakelijkheid werd gebaseerd op de wet van 30 juli 1979 betreffende de preventie van brand en ontploffing en betreffende de verplichte verzekering van de burgerlijke aansprakelijkheid in dergelijke gevallen, BS 20 september I979.

IOI Cass. 5 juni 2008, RW 2008-2009, 795, noot S. LIERMAN en JT 2009, 28, noot A. PUTZ; H. BOCKEN, 'Geen kans verloren. Causale onzekerheid en de rechtspraak van het Hof van Cassatie over het verlies van een kans', Postuniversitaire Cyclus Willy Delva. Aansprakelijkheid, aansprakelijkheidsverzekering en andere schadevergoedingssystemen, Mechelen, Kluwer, 2007, $27 \mathrm{I}$ e.v.

I02 Cass. 23 september 1974, Arr.Cass. I975, 97, Pas. I975, I, 87, RGAR I976, nr. 9659, noot R.O. DALCQ en JCP 1976, II, nr. I8.216, noot R. SAVATIER. 
dus onvoldoende zekerheid in betreffende het causaal verband tussen de fout en het overlijden. ${ }^{103}$ In zo'n geval van onzeker causaal verband dringt de vrijspraak zich op. Uit die strafrechtelijke vrijspraak volgt het verbod voor de burgerlijke rechter om in een burgerlijke procedure te beslissen dat de arts de dood van of verwondingen aan het slachtoffer heeft veroorzaakt en om schadevergoeding op basis daarvan toe te kennen. Het gezag van strafrechtelijk gewijsde verbiedt hem dit. Maar niets belet de burgerlijke rechter de arts te veroordelen tot schadevergoeding wegens het verlies van overlevings- of genezingskansen. De strafrechter heeft zich immers enkel uitgesproken over (het onzeker) causaal verband tussen de fout en het overlijden/ slagen en verwondingen. Het strafrechtelijk gezag van gewijsde is daartoe beperkt. De burgerlijke rechter is dan ook vrij zich uit te spreken over een ander soort schade, $\mathrm{nl}$. het verlies van genezings- of overlevingskansen. ${ }^{\mathrm{IO}}$

\subsubsection{De gerechtelijke of menselijke zekerheid}

3I. Moet uit het voorgaande worden afgeleid dat het strafrecht op het vlak van het causaal verband strenger is dan het burgerlijk aansprakelijkheidsrecht en een absoluut zeker causaal verband vereist? Sommige auteurs menen inderdaad dat het causaliteitsbegrip in strafzaken en burgerlijke zaken essentieel verschilt, ${ }^{105}$ dat het strafrecht strengere eisen stelt aan het causaal verband door uit te gaan van een absolute zekerheid over het causaal verband, gelet op het in dubio pro reo-uitgangspunt. ${ }^{\text {106 }}$

Dit moet o.i. worden gerelativeerd en is eerder in verband te brengen met de verliesvan-een-kans-theorie die wel in het burgerlijk aansprakelijkheidsrecht en niet in het strafrecht wordt aanvaard. Het concept van de kansleer is nu eenmaal zo dat het eerder geschikt is voor het burgerlijk recht dan voor het strafrecht. In het aansprakelijkheidsrecht is er geen voldoende zekerheid over het causaal verband tussen de fout en de integrale schade, dus krijgt men ook geen integrale schadevergoeding, wat nochtans de regel is. Maar men kan wel aanspraak maken op een kleinere schadevergoeding, als men kan aantonen dat er een causaal verband bestaat met het verlies van een kans de schade te vermijden of een voordeel te bemachtigen. Dit concept

I03 H. BOCKEN, 'Het causaal verband tussen misdrijf en schade', in A. DE NAUW, J. D'HAENENS en M. STORME (eds.), Actuele Problemen van Strafrecht, XIVe Postuniversitaire Cyclus Willy Delva, Antwerpen, Kluwer, I988, 459; J. DE CODT, 'L'appréciation de la causalité dans le jugement des actions publique et civile', in M. MANDOUX en O. KLEES (eds.), Actualités de droit pénal et de procédure pénale, Editions de Jeune Barreau de Bruxelles, 200I, 73; A. DE NAUW, Inleiding tot het bijzonder strafrecht, Mechelen, Kluwer, 20I0, 22I.

Io4 T. VANSWEEVELT, De civielrechtelijke aansprakelijkheid van de geneesheer en het ziekenhuis, Antwerpen, Maklu, I992, nr. 543; S. VAN OVERBEKE, 'De arts in de beklaagdenbank. De medische fout deskundig en strafrechtelijk gezondheidszorg(dis)kwalificeerd', in F. DERUYCK en M. ROZIE (eds.), Het strafrecht bedreven. Liber Amicorum Alain De Nauw, Brugge, die Keure, 20II, 928-93I.

I05 P. WAETERINCKX en K. DE SCHEPPER, 'Enkele bedenkingen bij de objectivering van de beoordeling van de strafrechtelijke verantwoordelijkheid in het ondernemingsstrafrecht', in M. FAURE en W. RAUWS (eds.), Recente ontwikkelingen in het arbeids-, economisch, straf- en familierecht. Huldeboek voor Mr. Jos Van Goethem, Antwerpen, Intersentia, 2009, I58.

Io6 In die zin: M. FAURE en J. VANHEULE, Milieustrafrecht, in APR, Mechelen, Kluwer, 2006, nr. 506: 'Strafrechtelijk wordt gelet op het vermoeden van onschuld en het in dubio pro reo-uitgangspunt in Belgiëeen absolute zekerheid van het causaal verband vereist.' 
van gedeeltelijke schadevergoeding is moeilijk transponeerbaar naar het strafrecht, nu een misdrijf ondeelbaar is en men bezwaarlijk veroordeeld kan worden tot een gedeeltelijke straf voor het gedeeltelijk veroorzaken van een misdrijf.

32. Anders dan hierboven door de vermelde auteurs verdedigd, is een absolute zekerheid over het bestaan van het causaal verband evenwel niet vereist, noch in het buitencontractueel aansprakelijkheidsrecht, noch in het strafrecht.

In het buitencontractueel aansprakelijkheidsrecht volstaat een zogenoemde 'gerechtelijke zekerheid', dit is een hoge graad van waarschijnlijkheid zodat de rechter niet meer ernstig aan het tegendeel hoeft te denken, hoewel dit theoretisch mogelijk blijft. ${ }^{107}$ Immers, ook hier is er steeds een onzekerheid. De vraag die men stelt, is wat er zou zijn gebeurd indien men de fout of de andere aansprakelijkheidsgrond wegdenkt en vervangt door een rechtmatig alternatief. Men vraagt zich dus af wat zich in die hypothese zou hebben voorgedaan, hoewel dit zich niet in werkelijkheid heeft voorgedaan, waardoor er altijd een onzeker element blijft bestaan.

Wat de vereiste graad van zekerheid betreft, volstaat ook in het strafrecht een gerechtelijke zekerheid. In strafzaken beoordeelt de rechter op onaantastbare wijze de bewijswaarde van de regelmatig door de partijen overgelegde gegevens waarover de partijen tegenspraak hebben kunnen voeren. Net zoals in burgerlijke zaken zal de rechter in strafzaken zich baseren op zijn innerlijke overtuiging of morele zekerheid. ${ }^{108}$ De rechter zal de beklaagde pas veroordelen wanneer hij de menselijke zekerheid heeft over en elke redelijke twijfel uitgesloten is nopens de schuld en het causaal verband tussen die schuld en de schade (overlijden, letsels). ${ }^{\text {109 }}$

De feitenrechters stellen zich dan ook tevreden met een voldoende zeker causaal verband $^{\text {IIo }}$ of met een aan zekerheid grenzend waarschijnlijk causaal verband. ${ }^{\text {III }}$

IO7 M. VAN QUICKENBORNE, De oorzakelijkheid in het recht van de burgerlijke aansprakelijkheid. Een methodologisch en positief-rechtelijke analyse, Brussel, Elsevier-Sequoia, I972, nr. 219; H. DE RODE, 'Le lien de causalité', in Responsabilités. Traité théorique et pratique, Dossier II, Diegem, Kluwer, I998, 9 .

Io8 P. TRAEST, Het bewijs in strafzaken, Gent, Mys \& Breesch, I992, nrs. 888 e.v.; R. VERSTRAETEN, Handboek strafuordering, Antwerpen, Maklu, 20I2, nrs. 2005 en 2027.

Io9 Cass. Io november 1992, Arr.Cass. I99I-92, I294.

IIo Zie bv. Luik 27 januari I966, Jur.Liège I965-66, 209 ('une certitude suffisante'); zie voor een recente toepassing van het criterium van de voldoende zekerheid in Nederland, Rb. Den Haag I6 juli 20I4, ECLI:NL:RBDHA:20I4:8562; in deze 'Moeders van Srebrenica'-zaak werd de Nederlandse Staat aansprakelijk gesteld voor het overlijden van vluchtelingen die op de compound verbleven, wegens de medewerking die Dutchbat had verleend aan de deportatie van mannelijke vluchtelingen door de Bosnische Serviërs; over het causaal verband oordeelde de rechtbank als volgt: 'Naar het oordeel van de rechtbank is voldaan aan het voor aansprakelijkheid van de Staat vereiste van causaal verband, aangezien met voldoende mate van zekerheid vaststaat dat de mannen in weerbare leeftijd die op de compound verbleven het er levend zouden hebben afgebracht als Dutchbat niet had meegewerkt aan hun deportatie.'

III Zie bv. Antwerpen 26 maart I993, TMR I993, 239. 
De twijfel die de beklaagde ten goede moet komen, is trouwens de twijfel van de rechter en niet die van een ander persoon zoals een gerechtsdeskundige die slechts een advies uitbrengt. ${ }^{\mathrm{II} 2}$ Zonder de bewijskracht van het deskundigenverslag te miskennen, kan de feitenrechter oordelen dat er een menselijke zekerheid is over het causaal verband tussen een fout en een schadegeval, terwijl dit voor de gerechtsdeskundige slechts 'waarschijnlijk' of 'niet voor Ioo\% zeker' was. ${ }^{\text {I13 }}$

De rechter die geen zekerheid heeft dat zonder het gebrek aan voorzorg of voorzichtigheid de letsels zich niet op dezelfde wijze zouden hebben voorgedaan, kan de beklaagde niet schuldig verklaren. Daarvoor is evenwel niet vereist dat de rechter dit causaal verband moet uitsluiten. ${ }^{\mathrm{II} 4}$ Het volstaat dat de rechter oordeelt dat niet met zekerheid tot het causaal verband tussen de fout en de letsels kan worden besloten.

\subsection{De oorzakelijkheid van een nalaten}

33. Het bewijs van de causaliteit van een nalaten brengt soms specifieke problemen met zich. Men zal niet alleen moeten aantonen dat de nalatigheid een fout was, maar ook dat in de historische reconstructie van het verhaal de verzuimde handeling de schade had kunnen voorkomen. Het is post factum moeilijk met zekerheid aan te tonen dat het schadegeval zich niet zou hebben voorgedaan indien de handeling wel gesteld was geweest.

Twee voorbeelden kunnen dit illustreren. Een vrouw belt de politie en krijgt agent Janssens aan de lijn aan wie zij in paniek vertelt dat haar ex-geliefde bezig is haar lastig te vallen, te bedreigen en geweld pleegt. De politie talmt en komt pas drie uur na de oproep langs. Inmiddels heeft de ex-minnaar de vrouw begoten met zwavelzuur. ${ }^{\mathrm{II}}$ Is de politieagent strafrechtelijk aansprakelijk voor het nalaten op te treden? In casu bestaat er geen zekerheid of passende beschermingsmaatregelen van de politie de geweldpleging hadden kunnen voorkomen. Zeker bij opzettelijke gewelddaden is het nagenoeg onmogelijk te bewijzen dat veiligheidsmaatregelen de schade zouden hebben voorkomen.

Gelijkaardige causaliteitsproblemen doen zich evenwel voor buiten de sfeer van de opzettelijke gewelddaden. Wanneer een gynaecoloog een dringende telefonische oproep krijgt om zich naar het ziekenhuis te begeven voor een complexe bevalling en hij/zij daar niet onmiddellijk gevolg aan geeft, rijst de vraag of een onmiddellijke reactie het leven van de moeder en het kind had kunnen redden. ${ }^{\text {II6 }}$

II2 Cass. 25 mei I994, RW I994-I995, II89, noot S. VAN OVERBEKE.

II3 S. VAN OVERBEKE, 'De arts in de beklaagdenbank. De medische fout deskundig en strafrechtelijk gezondheidszorg(dis)kwalificeerd', in F. DERUYCK en M. ROZIE (eds.), Het strafrecht bedreven. Liber Amicorum Alain De Nauw, Brugge, die Keure, 20II, 927.

II4 Cass. I februari 20II, A.R. P.ro.I354.N.

II5 Vgl. de feiten in Cass. I april 2004, JT 2005, 357, noot N. ESTIENNE, NjW 2005, 628, noot S. LIERMAN, RW 2004-05, I06, noot I. BOONE en TBBR 2005, 368, noot C. EYBEN.

II6 T. VANSWEEVELT, 'Rechtsverhoudingen, aansprakelijkheid en schadevergoeding in de gezondheidszorg', in T. VANSWEEVELT en F. DEWALLENS (eds.), Handboek Gezondheidsrecht, Volume I, Antwerpen, Intersentia, 2014, nrs. 2793 e.v. 
Meer dan eens zal het causaal verband onzeker zijn en zal een veroordeling wegens onopzettelijke doding problematisch zijn.

34. De Nederlandse Hoge Raad heeft aanvaard dit causaliteitsprobleem bij nalaten op te lossen door het begrip van de risico- of gevaarsverhoging in te bedden in de theorie van de toerekening naar redelijkheid. ${ }^{117}$ In deze zaak hadden ouders hun twee maanden oud kind ernstig verwaarloosd (kind had groot aantal ribben gebroken en breuken in de voorhoofdschedel) en was het kind overleden. Het was niet bewezen dat de ouders de letsels opzettelijk hadden toegebracht, maar wel dat zij als ouders hadden nagelaten tijdig de arts te waarschuwen, als gevolg waarvan het kind was overleden (art. $255^{\text {II } 8}$ jo. $257 \mathrm{Nedl}$. Sr.). Als verweermiddel werd ingeroepen dat het causaal verband onzeker was, nu het om een zeer ernstig hersenletsel ging en het niet uitgesloten was dat zelfs bij tijdig medisch ingrijpen het kind zou zijn overleden. De Hoge Raad oordeelde evenwel dat het verzuim van de ouders het gevaar voor overlijden van het kind in zodanige mate had verhoogd dat het overlijden redelijkerwijze aan de ouders kon worden toegerekend. ${ }^{\text {I9 }}$

Naar Belgisch recht heeft het Hof van Cassatie in een soortgelijke zaak deze 'risicoverhogingstheorie' afgewezen. Het hof van beroep te Bergen had vastgesteld dat de beslissing een persoon te hospitaliseren te laat was genomen en dit met zekerheid de risico's op overlijden van het slachtoffer had verhoogd. Hieruit leidde het beroepshof af dat de fout in een noodzakelijk causaal verband stond met het overlijden. Het Hof van Cassatie vernietigde evenwel dit arrest en oordeelde dat men uit een risicoverhoging geen causaal verband tussen de fout en een overlijden kan afleiden. ${ }^{120}$

35. Weliswaar biedt het Belgische recht wel andere mogelijkheden om deze bewijsproblemen op te vangen.

Wie, zoals in de aangegeven voorbeelden, verzuimt hulp te verlenen aan een persoon in groot gevaar, kan veroordeeld worden wegens schuldig verzuim (art. 422 bis Sw.). Het misdrijf schuldig verzuim vervult hier de rol van 'opvangmisdrijf' voor dit soort situaties, nu het geen causaal verband vereist tussen de nagelaten handeling en de doeltreffendheid ervan. Artikel 422bis Sw. bestraft de bewuste en opzettelijke onverschilligheid, de egoïstische weigering om hulp te bieden. Het hulpverzuim op zich volstaat om bestraft te worden, ongeacht de gevolgen of het bereikte resultaat.

II7 Cf. G. MEIJER, A. SEUTERS en R. TER HAAR, Leerstukken strafrecht, Deventer, Kluwer, 20Io, 272.

II8 Art. 255 Nedl. Sr. luidt als volgt: 'Hij die opzettelijk iemand tot wiens onderhoud, verpleging of verzorging hij krachtens wet of overeenkomst verplicht is, in een hulpeloze toestand brengt of laat, wordt gestraft met gevangenisstraf van ten hoogste twee jaren of geldboete van de vierde categorie.'

II9 HR 30 september 2013, NJ 2005, nr. 69, met strijdige conclusies van MACHIELSE en noot Kn.; zie hierover ook A. MACHIELSE, 'Oorzakelijkheid', in Het Wetboek van Strafrecht, Deventer, Kluwer, 2012, 20, nr. 9 .

I20 Cass. I7 september 2003, JT 2004, 95. 
De graad van doeltreffendheid van de hulp, de onhandigheid of de ontoereikendheid ervan heeft geen belang. ${ }^{\text {I2I }}$

Op civielrechtelijk vlak tracht de rechtspraak deze bewijsproblematiek te ondervangen door een beroep te doen op de verlies-van-een-kanstheorie: het verzuim een handeling te stellen heeft aan de benadeelde minstens de kans ontnomen op vermijding van de schade of het gevaar. ${ }^{122}$

\subsection{Pluraliteit van oorzaken}

36. Bij pluraliteit van oorzaken, komen verschillende fouten als oorzaak van de schade in aanmerking. Voor elke fout afzonderlijk moet dan het conditio sine qua non-verband met de schade worden nagegaan. ${ }^{123}$

Dit betekent o.m. dat het gebrek aan causaal verband tussen fout A en de schade niet kan worden afgeleid uit het enige feit dat de schade zich niet zou hebben voorgedaan zonder fout B. ${ }^{124}$ Het causaal verband van fout B in het schadegebeuren is dus geen voldoende argument om het conditio sine qua non-verband tussen fout $\mathrm{A}$ en de schade te ontkennen. Het schadegeval kan immers verschillende oorzaken hebben. Het gebrek aan causaal verband tussen fout A en de schade kan pas worden aanvaard wanneer de rechter vaststelt dat het schadegeval zich ook zou hebben voorgedaan bij afwezigheid van fout $\mathrm{A}$.

Voorbeelden van deze regel vinden we vaak terug in verkeersongevallen. Zo was bestuurder A voorrang verschuldigd en had hij de fout begaan op de middelste rijstrook tegen de rijrichting in te rijden. Het hof van beroep te Luik besliste evenwel dat de fout van A niet in causaal verband stond met het ongeval, nu A voor autobestuurder B geen onvoorziene hindernis opleverde. Uit de omstandigheid dat bestuurder B een fout in causaal verband met het verkeersongeval heeft begaan, kan nochtans niet worden afgeleid dat de schade zich zonder de fout van A toch zou hebben voorgedaan, zoals ze zich heeft gerealiseerd. ${ }^{125}$

37. Bij pluraliteit van oorzaken worden de causaliteitsvragen wel neteliger, nu de ene oorzaak een rechtstreekser verband kan hebben met de schade dan de andere. Verschillende problemen doen zich dan voor: moet aan de ene oorzaak een groter

I2I Cass. 7 november 20I2, T.Gez.|Rev.dr.santé 20I2-20I3, 3I0, noot N. COLETTE-BASECQZ; dit arrest vernietigt Brussel 20 april 2012, T.Gez./Rev.dr.santé 2012-2013, 305; A. DE NAUW, Inleiding tot het bijzonder strafrecht, Mechelen, Kluwer, 20I0, 234; J. ROZIE, 'Verloren tijd wordt nooit teruggevonden. Een analyse van het healingarrest', $\mathrm{NC} 20 \mathrm{I}_{3}, 40 \mathrm{I}$.

I22 Zie ook J. ROZIE, 'Verloren tijd wordt nooit teruggevonden. Een analyse van het healingarrest', $\mathrm{NC} 2013,394$.

I23 Cass. 24 maart 2005, Pas. 2005, I, 703.

I24 Zie o.m. Cass 17 april I975, Arr.Cass. I975, 908 en Pas. I975, I, 820; zie ook Cass. Io maart I975, Arr Cass. I975, 773 en Pas. I975, I, 70I; R.O. DALCQ en F. GLANSDORFF, 'Examen de jurisprudence (I973-I979). La responsabilité délictuelle et quasi délictuelle’, RCJB I98I, Io8.

I25 Cass. 29 november 1995, Arr.Cass. I995-96, I053 en Pas. I996, I, 1086. 
belang worden gehecht dan aan de andere; wat indien niet kan worden uitgemaakt welke oorzaak juist de schade heeft veroorzaakt, of wat indien de oorzaak denkbeeldig is? Deze vragen worden hierna beantwoord.

\subsubsection{Rechtstreekse en onrechtstreekse oorzaken}

38. Het is niet vereist dat een fout de enige oorzaak zou zijn van het schadegeval. ${ }^{\mathrm{I} 6}$ Noch moet een fout de rechtstreekse oorzaak zijn van de schade om de aansprakelijkheid van de dader in het gedrang te brengen. Bij pluraliteit van oorzaken geldt eveneens de equivalentietheorie: elke fout zonder dewelke de schade zich niet zou hebben voorgedaan, zoals ze zich in concreto heeft gerealiseerd, wordt als oorzaak van de schade beschouwd. Zowel de fouten die in rechtstreeks als in onrechtstreeks verband staan met de schade, komen aldus als oorzaak van de schade in aanmerking. ${ }^{127}$ Immers, zoals gezegd, alle oorzaken zijn, rechtstreeks of onrechtstreeks, gelijkwaardig.

Dit is ook het officiële standpunt van het Hof van Cassatie. Klassiek luidt de cassatierechtspraak dan ook dat de artikelen 4I8-420 Sw. niet alleen strafbaar stellen de fout van degene die rechtstreeks de schade (het doden, de slag en de verwonding) heeft veroorzaakt, maar ook de fout van hen die door hun toedoen ertoe bijgedragen hebben het te veroorzaken. ${ }^{228}$

39. Weliswaar is er recente rechtsleer ${ }^{129}$ die een rechtstreeks causaal verband vereist tussen de fout van de dader en het letsel van het slachtoffer. Deze auteurs onderbouwen hun standpunt door te verwijzen naar twee cassatiearresten. Deze arresten moeten dus worden geanalyseerd. Op de keper beschouwd vereist het Hof van Cassatie in de aangehaalde arresten evenwel geenszins een rechtstreeks causaal verband.

In het cassatiearrest van 3 mei $196 \mathrm{I}^{130}$ stelt het Hof van Cassatie enkel vast dat het bestreden arrest de veroordeling van de dader wettelijk rechtvaardigt door vast te

I26 Cass. 6 oktober I975, Arr.Cass. I976, I59 en Pas. I996, I, Io86 (veroordeling wegens onopzettelijke slagen en verwondingen bij samenloop overdreven snelheid autobestuurder en verblinding door koplichten niet-geïdentificeerd voertuig); Cass. I4 mei 2008, Arr.Cass. 2008, II82 (veroordeling wegens onopzettelijke slagen en verwondingen bij samenloop fout bestuurder, controleverlies over voertuig, en twee onregelmatig geparkeerde voertuigen op baan van stuurloos voertuig); Cass. II februari 2009, Arr.Cass. 2009, 482.

I27 H. DE PAGE, Traité élémentaire de droit civil belge, II, Brussel, Bruylant, I964, nr. 960 ; J.L. FAGNART, 'Petite navigation dans les méandres de la causalité', RGAR 2006, nr. I4080, randnr. 5.

I28 Cass. 29 oktober I962, RW I962-63, I886; Cass. I6 oktober I972, Arr.Cass. I973, I65 en Pas. I973, I, I65.

I29 F. VAN VOLSEM, 'Culpa in het Belgisch strafrecht: een poging tot synthese', in Preadviezen 2012. Vereniging voor de vergelijkende studie van het recht van België en Nederland, Den Haag, Boom Juridische uitgevers, 2012, II5; J. DE HERDT, Fysiek persoonlijk geweld. Een onderzoek naar de accuraatheid en coherentie van de strafrechtelijke kwalificaties en instrumenten aangewend als reactie op fysiek interpersoonlijk geweld, Antwerpen, Intersentia, 20I4, nrs. Io8 en 654 .

r30 Cass. 3 mei ig6r, Pas. r96r, I, 94I. 
stellen dat de dader een fout heeft begaan in een rechtstreeks en noodzakelijk verband met de lichamelijke letsels. Uit het arrest kan niet worden afgeleid dat het Hof van Cassatie zelf een rechtstreeks causaal verband vereist.

In het door een andere auteur aangehaald cassatiearrest van I6 oktober $2008^{131}$ draait het om een verzekeringsovereenkomst die voorzag in een dekking van het debetsaldo van een bankrekening in geval van overlijden van de verzekerde dat rechtstreeks en uitsluitend te wijten is aan een ongeval. Het opgeworpen juridisch probleem was hier in de eerste plaats van verzekeringsrechtelijke aard: is een verkeersongeval de enige en directe doodoorzaak bij een slachtoffer dat ook een pathologische voorbeschiktheid vertoonde als gevolg van een aantasting van de hartslagaders? Uit een strafrechtelijke veroordeling (van de autobestuurder) wegens onopzettelijke doding, kan een burgerlijke rechter niet afleiden dat het overlijden van het slachtoffer rechtstreeks en uitsluitend aan het verkeersongeval te wijten is, zo oordeelde het Hof van Cassatie. Voor een veroordeling wegens onopzettelijke doding moet het overlijden voortvloeien uit een fout, zonder dat vereist is dat die fout de enige oorzaak van dat overlijden is. Uit dit cassatiearrest kan dus al evenmin worden afgeleid dat het Hof van Cassatie een rechtstreeks causaal verband vereist tussen een fout en het letsel of het overlijden.

Het vereisen van een rechtstreeks causaal verband zou trouwens indruisen tegen de essentie van de equivalentietheorie. Ongeacht het rechtstreeks of onrechtstreeks karakter van het causaal verband, het volstaat aldus dat een fout een noodzakelijke voorwaarde is geweest voor het misdrijf zoals het zich heeft voorgedaan.

40. De rechtspraak bevat talrijke voorbeelden van aansprakelijkheden voor op onrechtstreekse wijze veroorzaakte schade in overeenstemming met de equivalentietheorie. Als regel geldt dat een tussenkomende fout of factor van een derde het causaal verband niet doorbreekt. ${ }^{132}$ Bijgevolg werkt de tussenkomende fout of factor van een derde niet bevrijdend in het raam van de artikelen 4 I8-420 Sw. ${ }^{\mathrm{I} 3}$

Zo werd het onrechtstreeks causaal verband aanvaard tussen de fout van de schadeverwekker waardoor een kind om het leven komt en de daaropvolgende zenuwinzinking van de moeder van het overleden kind ${ }^{\mathrm{r} 34}$ of in een soortgelijke zaak tussen de fout die leidt tot de dood van een kind en de zware depressieve toestand gevolgd door zelfmoord van de vader van het overleden kind, ${ }^{\mathrm{I} 35}$ tussen de fout van

I3I Cass. I6 oktober 2008, Arr.Cass. 2008, 2246 en NjW 2008, 836, noot GJ.

I32 L. DUPONT en R. VERSTRAETEN, Handboek Belgisch Strafrecht, Acco, Leuven, I990, I93.

I33 J. DE CODT, 'L'appréciation de la causalité dans le jugement des actions publique et civile', in M. MANDOUX en O. KLEES (eds.), Actualités de droit pénal et de procédure pénale, Editions de Jeune Barreau de Bruxelles, 200I, 72.

I34 Luik I6 april I99I, RGAR I992, nr. I2.033.

I35 Luik 25 juni I986, RGAR I988, nr. II.370; in die zin ook Cass. 22 november I97I, Arr.Cass. I972, 290: veroordeling wegens onopzettelijke doding is gerechtvaardigd, wanneer het slachtoffer van een ongeval datlichamelijk letsel heeft teweeggebracht zelfmoord heeft gepleegd, indien het overlijden van het slachtoffer in causaal verband staat met het trauma dat hij op het ogenblik 
een verkoper vuurpijlen te hebben verkocht aan een minderjarige jonger dan zestien jaar, die de vuurpijlen doorgeeft aan een speelkameraad die ze aansteekt, en de lichamelijke letsels die de pijlen bij een kind hebben veroorzaakt, ${ }^{136}$ tussen de fout van een autobestuurder die een verkeersongeval veroorzaakt en de schade die het slachtoffer overhoudt aan ofwel de complicaties van een medische ingreep ${ }^{137}$ ofwel de gevolgen van een foutief uitgevoerde medische ingreep, ${ }^{138}$ en tussen de fout van een café-uitbater die aan een dronken persoon nog alcoholische dranken schenkt en het verkeersongeval dat laatstgenoemde nadien veroorzaakt. ${ }^{139}$

Wanneer verschillende personen door hun fout hebben bijgedragen tot het misdrijf, kunnen zij allen als dader van het misdrijf worden veroordeeld. ${ }^{10}{ }^{\circ}$ Zodra zonder hun fout de schade zich niet zou hebben voorgedaan, zoals ze zich heeft voorgedaan, staat hun fout in causaal verband met de schade. Het is dan irrelevant of de fout van de ene beklaagde in rechtstreeks verband en de fout van de andere beklaagde in onrechtstreeks verband staat met de schade. Zo kan zowel de onvoorzichtige autobestuurder die aan een te hoge snelheid en op een weg met een diepe en gevaarlijke straatgoot de agglomeratie inrijdt en mensen verwondt, als de werkgever die als passagier verzuimt het bevel te geven aan de autobestuurder om te vertragen, aansprakelijk worden gesteld op grond van de artikelen $4 \mathrm{I} 8-420 \mathrm{Sw} \cdot{ }^{\mathrm{I}}{ }_{\mathrm{I}}$

4I. De aanvaarding van een onrechtstreeks causaal verband tussen een fout en de schade, voor een veroordeling wegens onopzettelijke doding of onopzettelijk toebrengen van slagen en verwondingen, brengt ook met zich mee dat het voor zo'n veroordeling niet vereist is dat de dader moet hebben kunnen voorzien wie uiteindelijk schade zou lijden. Dit blijkt niet alleen uit een aantal van de in het vorig randnummer vermelde voorbeelden, maar ook uit volgend arrest. Een drugdealer verkoopt een onverantwoord grote hoeveelheid amfetamines aan een tussenpersoon, die het op zijn beurt doorverkoopt aan een tussenpersoon, die het dan aan een druggebruiker bezorgt die aan de overdosis overlijdt. De oorspronkelijke verkoper van de dodelijke hoeveelheid amfetamines kan worden veroordeeld wegens onopzettelijke doding, nu zonder zijn fout de overdosis niet tot bij het slachtoffer zou zijn geraakt en hij bovendien schade kon voorzien, ook al kon de beklaagde niet voorzien wie uiteindelijk schade zou lijden. ${ }^{\mathrm{I} 2}$

van het ongeval heeft geleden; dat een zelfdoding de veroordeling wegens onopzettelijke doding niet uitsluit, wordt ook uitvoerig aangetoond in J. ROZIE, 'Zelfdoding en strafrecht: het taboe doorbroken', RW 2013-2014, 294-297.

I36 Gent 7 januari I986, RW I986-87, 2660.

I37 Cass. I8 juni 1973, Arr.Cass. 1973, I0I5 en Pas. I973, I, 968; Cass. I5 oktober I973, Arr.Cass. I974, I77 en Pas. I974, I, I62.

I38 Vgl. Rb. Turnhout 4 juni i984, RW I986-87, 2646, noot T. VANSWEEVELT.

I39 Pol. Brugge 3 oktober 2006, T.Pol. 2007, 226, noot.

I40 J. VANHEULE, Strafbare deelneming, Antwerpen, Intersentia, 20I0, 39I-392, nr. 305.

I4I Cass. 3 maart I924, Pas. I924, I, 229; zie ook Cass. 6 juli I925, Pas. I925, I, 329: een werkgever wordt veroordeeld wegens onopzettelijke doding, omdat hij een chauffeur de opdracht gaf te rijden met een vrachtwagen waarvan hij wist dat die zich in een zeer slechte staat bevond, waardoor de chauffeur de Schelde inreed en omkwam.

I42 Cass. 8 augustus I990, Arr.Cass. I989-I990, I42I. 
Bij opzettelijke geweldpleging is schade altijd voorzienbaar. Zodra slagen opzettelijk worden toegebracht, staat de dader ervan in voor de gevolgen die eruit voortvloeien. Voor de toepassing van de artikelen 399 en 400 Sw. (opzettelijke slagen met ziekte of arbeidsongeschiktheid tot gevolg) is het aldus niet noodzakelijk dat de dader het tastbare gevolg van de opzettelijke geweldpleging heeft voorzien of heeft kunnen voorzien. ${ }^{\mathrm{I}} 3$

42. Het onderscheid tussen rechtstreekse en onrechtstreekse oorzaken en tussen rechtstreekse en onrechtstreekse schade biedt eigenlijk in het raam van de causaliteit geen meerwaarde. Telkens moet men zich afvragen of de schade en het causaal verband tussen de fout en de schade voldoende zeker zijn. Bij sommige schadegevallen kan de schade evenwel zo uitdijen en zich verwijderen van de oorspronkelijke schade, dat het gezond verstand aangeeft dat het causaal verband te onzeker wordt.

43. In dit verband moet worden gewezen op rechtspraak van het Hof van Cassatie waarin het Hof aanvaardt dat in specifieke omstandigheden het causaal verband tussen een door een menselijke fout ontstane onregelmatige, maar voorzienbare toestand en het daaropvolgende schadegeval verbroken wordt wanneer er eveneens een andere fout van een derde in causaal verband staat met dit schadegeval.

Een voorbeeld kan dit illustreren. In het zogenoemde tractorarrest van 6 september $1988^{\mathrm{r} 44}$ gebeurde er een ongeval op een treinspoor in het havengebied van Antwerpen. Op een plaats waar de treinsporen over drukke rijbanen lopen, stond een tractor stil. Een trein die $20 \mathrm{~m}$ verder staat, vertrok en reed tegen $5 \mathrm{~km}$ per uur de stilstaande tractor aan. De feitenrechter weigerde de NMBS (Nationale Maatschappij der Belgische Spoorwegen) schadevergoeding toe te kennen, omdat noch het verbod om stil te staan op de treinsporen, noch de voorrang van het treinverkeer, de treinbestuurder ontslaat van de algemene plicht tot voorzichtigheid. In het middel beriep de NMBS zich op de equivalentieleer: zonder de fout van de tractorbestuurder had de schade zich niet voorgedaan zoals ze zich in concreto heeft voorgedaan. Het Hof van Cassatie verwierp het cassatiemiddel en overwoog dat de omstandigheid dat een verkeersongeval niet gebeurd zou zijn zonder een door een menselijke fout ontstane onregelmatige toestand niet noodzakelijk meebrengt dat die fout in oorzakelijk verband staat met de totstandkoming van dit verkeersongeval en/of de schadelijke gevolgen ervan. De rechter kan uit de feitelijke gegevens wettig besluiten dat het ongeval wat het totstandkomen en de schadelijke gevolgen ervan betreft, uitsluitend zijn oorzaak vindt in een andere door hem vastgestelde fout.

I43 Cass. 22 oktober 2008, Arr.Cass. 2008, 2333; zie ook Cass. I9 december 2006, Arr.Cass. 2006, 2697; A. DELANNAY, 'Les homicides et lésions corporelles volontaires', in Les infractions. Volume 2. Les infractions contre les personnes, Brussel, Larcier, 2010, 304.

I44 Cass. 6 september I988, Arr.Cass. I988-89, I2, Pas. I989, I, 8 en Verkeersrecht, I989, 74. 
In dezelfde zin oordeelde het Hof van Cassatie in volgende zaak. Naar aanleiding van een verkeersongeval wil een voetgangster hulp verlenen aan de bestuurder die zich in het verhakkeld voertuig bevindt. Zij steekt daarvoor op onvoorzichtige wijze een drukke rijbaan over en wordt gegrepen door een voorranghebbend voertuig. Is de veroorzaker van het eerste verkeersongeval nu aansprakelijk voor de schade veroorzaakt aan de voetgangster? Het Hof van Cassatie oordeelt dat het causaal verband tussen het eerste ongeval en de schade van de voetgangster mag worden uitgesloten, nu de voetgangster, die de wettige rechtvaardiging van artikel 422bis Sw. niet kan inroepen, een inbreuk heeft begaan op het Wegverkeersreglement waardoor zij zichzelf ernstig in gevaar bracht en zij deze overtreding ook makkelijk had kunnen vermijden.

Men kan zich moeilijk van de indruk ontdoen dat het Hof van Cassatie opnieuw de toepassing van de equivalentieleer wil temperen wanneer een fout slechts de onrechtstreekse oorzaak is van het schadegeval en bovendien ook lichter van aard is dan de zwaardere fout van de rechtstreekse schadeverwekker. Jammer is wel dat het Hof dit niet verder kadert in een algemene visie op het probleem van de onrechtstreekse oorzaken.

\subsubsection{De denkbeeldige andere oorzaak}

44. Het causaal verband moet worden aangetoond tussen de fout van de dader en de concrete schade. ${ }^{155}$ De feitenrechter moet vaststellen of de schade, zoals zij zich in concreto heeft voorgedaan, zich al dan niet zonder de fout zou hebben gerealiseerd. De loutere vaststelling dat de schade zich ook zonder de fout had kunnen voordoen, is daarbij in beginsel irrelevant. De andere oorzaak is dan niet daadwerkelijk, maar slechts denkbeeldig aanwezig.

De voorwaarde van de beoordeling van de concrete schade, komt meermaals aan bod bij diefstal of gevaarlijke activiteiten waartoe de schadeverwekker heeft beslist. Twee leerlingen verlaten ongeoorloofd de school en maken hiervan gebruik om vuurwerk te stelen. Door onvoorzichtige manipulatie van de vuurpijlen komen die tot ontploffing met schade tot gevolg. Het hof van beroep te Luik spreekt de onderwijzeres onder wier toezicht de leerlingen stonden, vrij van aansprakelijkheid, wegens het doorbreken van het causaal verband tussen haar fout en de schade. Het verlaten van de school impliceerde niet noodzakelijk dat de leerlingen zouden stelen en bovendien hadden de feiten zich op eender welk moment kunnen voordoen, in het bijzonder op een moment dat zij wel geoorloofd de school zouden hebben verlaten. Het Hof van Cassatie vernietigt het bestreden arrest en bevestigt dat door

I45 R.O. DALCQ, Traité de la responsabilité civile, in Les Novelles, Droit civil, II, Brussel, Larcier, I962, nrs. 24I6-24I8 en 2559; H. BOCKEN, 'Enkele hoofdthema's van de causaliteitsproblematiek', TBBR I988, 28I; M. VAN QUICKENBORNE, Oorzakelijk verband tussen onrechtmatige daad en schade, Mechelen, Kluwer, 2007, nrs. 52-53. 
die overwegingen niet wordt vastgesteld dat zonder de fout van de onderwijzeres de schade zich zou hebben voorgedaan zoals ze zich in concreto heeft gerealiseerd..$^{146}$

\subsubsection{De reserveoorzaak of hypothetische causaliteit}

45. In het vorig randnummer werd de hypothese besproken waarbij een denkbeeldige andere oorzaak de schade ook had kunnen doen ontstaan. Zoals gezegd wordt hiermee geen rekening gehouden. Nu gaat de aandacht naar de situatie waarin het conditio sine qua non-verband tussen een fout en de schade werd vastgesteld, maar het schadegeval zich ook had kunnen voordoen zonder die fout, als gevolg van een andere, latere oorzaak die echter in dit geval daadwerkelijk aanwezig is. Dit vormt de problematiek van de hypothetische causaliteit: ${ }^{147}$ een fout heeft een schadegeval veroorzaakt, terwijl het schadegeval zich ook had voorgedaan zonder die fout, maar als gevolg van een andere, later optredende 'hypothetische' oorzaak. Die hypothetische oorzaak kan ook de reserveoorzaak worden genoemd, omdat die dezelfde schade veroorzaakt, mocht de eerste oorzaak falen.

Klassiek is het voorbeeld van de situatie waarbij persoon A gif toedient aan persoon $\mathrm{B}$, die nadien wordt doodgeschoten door persoon $\mathrm{C}$, vooraleer het gif zijn uitwerking heeft gehad. A en C hebben beiden B willen vermoorden, kunnen zij nu beiden aansprakelijk worden gesteld?

46. De toepassing van de equivalentietheorie op deze gevallen van hypothetische causaliteit is problematisch. Immers, de schadeverwekker zou telkens kunnen aanvoeren dat aan de conditio sine qua non-test niet is voldaan. Ook zonder zijn fout zou het schadegeval zich hebben voorgedaan. Bijgevolg bestaat er geen oorzakelijk verband tussen zijn fout en de schade. De andere schadeverwekker kan echter hetzelfde aanvoeren, nu de reserveoorzaak evenmin een noodzakelijke voorwaarde is voor het schadegeval. De toepassing van de equivalentietheorie zou dan op het eerst gezicht tot gevolg hebben dat geen van beide oorzaken de schade heeft teweeggebracht. Bijgevolg zouden in deze redenering beide schadeverwekkers de aansprakelijkheidsdans ontspringen en zou het slachtoffer of zijn nabestaanden niet vergoed worden. Dit zou maatschappelijk onaanvaardbaar zijn.

De problematiek van de hypothetische oorzaak wordt daarom ook wel eens aangewend om de equivalentietheorie te bekritiseren, nu de toepassing ervan op deze gevallen tot een impasse zou leiden.

Nochtans hoeft die impasse zich niet voor te doen. Bij de problematiek van de hypothetische causaliteit dient voorrang te worden gegeven aan een regel die

I46 Cass. 24 maart 2005, Pas. 2005, I, 703.

I47 A.M. HONORE, 'Causation and remoteness of damage', in International Encyclopedia of Comparative law, XI, Torts, p. 79 e.v., nr. I26; M. VAN QUICKENBORNE, De oorzakelijkheid in het recht van de burgerlijke Aansprakelijkheid. Een methodologisch en positief-rechtelijke analyse, Brussel, Elsevier-Sequoia, I972, nrs. I8o e.v. 
gemeenschappelijk is aan de meeste causaliteitstheorieën, namelijk dat de fout of de aansprakelijkheidsfactor zich voorafgaand aan de schade moet voordoen. Samen met de regel van een juiste schadebegroting, kunnen zo deze gevallen op een meer heldere wijze worden benaderd.

47. In het gegeven voorbeeld van de opeenvolgende oorzaken die onmiddellijk schade veroorzaken, wordt enkel rekening gehouden met de eerste oorzaak. De initiële en reële oorzaak heeft de schade reeds veroorzaakt en dus dient het causaal verband tussen de initiële fout en de schade te worden bevestigd. De hypothetische oorzaak heeft geen invloed meer op het ontstaan van het schadegeval en dus worden er geen gevolgen aan verbonden. Zoals gezegd, moet de oorzaak de schade logischerwijze voorafgaan. Men kan een vermoorde persoon geen tweede keer vermoorden, of een vernielde zaak niet nogmaals vernielen. ${ }^{148}$ Het causaal verband tussen de initiële oorzaak en de schade kan niet meer in vraag worden gesteld door het enkele feit dat zich nadien, na het schadegeval, een opvolgende oorzaak heeft voorgedaan.

In het voorbeeld van het traag werkend vergif en de snellere schutter, zal dan ook enkel de schutter aansprakelijk gesteld worden, omdat enkel hij de dood van het slachtoffer heeft veroorzaakt. ${ }^{149}$ In dit voorbeeld achterhaalt de eigenlijke oorzaak dus eigenlijk de andere oorzaak. Op strafrechtelijk vlak zou de gifmenger weliswaar veroordeeld kunnen worden voor poging tot vergiftiging. ${ }^{150}$

\subsubsection{De niet-geïdentificeerde dader en de collectieve fout}

48. Het lijkt logisch dat in principe een schadelijk gevolg slechts kan worden toegerekend wanneer de dader kan worden geïdentificeerd. Vanuit strafrechtelijk oogpunt dient te worden benadrukt dat er geen strafrechtelijke verantwoordelijkheid bestaat voor andermans daad. Het bewijs van de identiteit van de dader is evenwel niet steeds een sinecure. De situatie kan zich voordoen waarbij een schadegeval wordt veroorzaakt door een lid van een groep personen, zonder dat de benadeelde de eigenlijke dader binnen die groep kan identificeren.

Stel dat een groep voetbalvandalen amok maakt, ruiten van winkels ingooit, wagens beschadigt, en een supporter van de tegenpartij verwondt. De verwonding is het werk van slechts één voetbalvandaal, die echter niet kan worden geïdentificeerd.

I48 Vgl. W. BOOM, 'Meervoudige oorzaken, hoofdelijke aansprakelijkheid en toerekening naar redelijkheid', in Causaliteit, Den Haag, Sdu Uitgevers, 2003, 97.

I49 J. RONSE, L. DE WILDE, A. CLAEYS en I. MALLEMS, Schade en schadeloosstelling, I, in APR, Gent, Story-Scientia, I984, nr. 494; H. COUSY en A. VANDERSPIKKEN, 'Causation under Belgian law', in Unification of tort law:causation, J. SPIER (ed.), Den Haag, Kluwer law international, 2000, 26; J.L. FAGNART, La causalité, Waterloo, Kluwer, 2009, nr. 83; M. VAN QUICKENBORNE, Oorzakelijk verband tussen onrechtmatige daad en schade, Mechelen, Kluwer, 2007, nr. 156.

I50 Zie de art. 52 en 397 Sw. 
Kan men geen causaal verband aantonen tussen de fout (of een andere aansprakelijkheidsgrond) van een bepaald persoon en de schade, dan kan in principe geen schadevergoeding worden toegekend. ${ }^{15}$ Anderzijds zou het onrechtvaardig zijn de benadeelde niet te vergoeden wanneer die wel een fout en de schade kan aantonen, maar niet specifiek binnen een groep de dader kan aanduiden en identificeren.

49. Om in deze situaties aan de bewijsnood van het slachtoffer tegemoet te komen, heeft de rechtspraak het begrip collectieve fout ontwikkeld. Deze theorie beschouwt de activiteit die heeft geleid tot het schadegeval als een fout van ieder die aan die activiteit heeft deelgenomen. Tussen die gemeenschappelijke activiteit en het schadegeval bestaat dan wel een causaal verband, zodat ieder voor dit schadegeval kan worden aangesproken en zij samen hiervoor aansprakelijk zijn. ${ }^{152}$ In feite wordt de oorzaak van de schade verplaatst van het rechtstreekse schadeverwekkend feit van een niet-geïdentificeerde persoon naar een daaraan voorafgaande fout die gemeenschappelijk is aan alle leden van de groep.

Het Hof van Cassatie lijkt deze theorie te hebben aanvaard in het cassatiearrest van 29 oktober 1962 . In deze zaak speelden drie kinderen voetbal op de openbare weg. Toen een van de spelers op doel schoot, kaatste de bal van het trottoir tegen een fietser die daardoor ernstig ten val kwam. Ofschoon in casu de identiteit van de doelschutter gekend was, aanvaardde het Hof van Cassatie toch de strafrechtelijke aansprakelijkheid van de drie voetballers op grond van artikel $4 \mathrm{I} 8 \mathrm{Sw}$. voor de verwondingen veroorzaakt door het begaan van een collectieve fout, namelijk het organiseren van een spel op de openbare weg in zulke omstandigheden dat het gevaarlijk was voor de voorbijgangers. ${ }^{153}$ Tot hetzelfde resultaat zou zijn beslist indien de identiteit van de rechtstreekse schadeverwekker gekend was, nu dan ook sprake was geweest van een collectieve fout die onrechtstreeks tot de schade heeft bijgedragen.

Ook in uitspraken van feitenrechters wordt deze theorie van de collectieve fout toegepast. ${ }^{154}$ In de strafprocedure zelf is het niet altijd voor de hand liggend deze theorie te hanteren. Het dient immers te worden benadrukt dat er geen strafrechtelijke aansprakelijkheid bestaat voor andermans daad en dat het persoonlijk karakter van de straf met zich meebrengt dat er geen straffen kunnen worden opgelegd aan

I5I Cass. 24 maart I98I, RW I98I-82, I980.

I52 I. GEERTS, 'Alternative liabilty under Belgian law: unknown and thus unloved?', Eur.Rev.Priv. Law I994, 445-446; H. COUSY en A.VANDERSPIKKEN, 'Causation under Belgian law', in Unification of tort law:causation, J. SPIER (ed.), Den Haag, Kluwer law international, 2000, 35; M. VAN QUICKENBORNE, Oorzakelijk verband tussen onrechtmatige daad en schade, Mechelen, Kluwer, 2007, nr. 77.

I53 Cass. 29 oktober I962, Pas. I963, I, 276, RW I962-63, I886 en J. I963, 99; zie ook J.L. FAGNART, La causalité, Waterloo, Kluwer, 2009, JT ig69, 277.

I54 Zie bv. Rb. Turnhout II februari I980, JT I98I, 362, noot F. SAUWEN (wanneer vier I3-jarige jongens elkaar bekogelen met steentjes en een jongen die zich verderop bevindt door een van die steentjes aan het oog wordt gekwetst zonder dat kan worden uitgemaakt van wie het steentje afkomstig is, dan kunnen de (ouders van de) vier jongens voor dit schadegeval aansprakelijk worden gesteld, nu hun gedrag als gevaarlijk en als een collectieve fout in causaal verband met de schade kan worden beschouwd). 
iemand die noch als dader, noch als medeplichtige werd veroordeeld. Een bewezenverklaring van het misdrijf is bovendien een voorwaarde om de burgerrechtelijke vordering voor de strafrechter gegrond te verklaren. ${ }^{155}$

50. Ook bij samenlopende fouten rijst deze problematiek waarbij verschillende personen betrokken zijn in een ongeval, maar de dader niet kan worden geïdentificeerd. Zo werd een bromfietser na een aanrijding met wagen A, op de autoweg gekatapulteerd waar hij uit zijn mond bloedend nog tekens van leven gaf. Even later komt een tweede wagen B aangereden die wel de bromfiets, maar te laat de bromfietser op de grond opmerkt en hem over een afstand van een tiental meter onder zijn wagen voortsleept. Het slachtoffer wordt naar het ziekenhuis gebracht waar hij twee uur later overlijdt. De gerechtsdeskundige stelt vast dat het slachtoffer is overleden aan ernstige hersenletsels, maar kan niet met zekerheid uitmaken welk voertuig de dodelijke letsels heeft veroorzaakt. Beide autobestuurders argumenteren dan ook enkel aansprakelijk te zijn voor onopzettelijke slagen en verwondingen. Het hof van beroep te Luik veroordeelt beide bestuurders evenwel wegens onopzettelijke doding, nu de samenloop van fouten de noodzakelijke voorwaarde was voor het overlijden van het slachtoffer. ${ }^{156}$

\subsubsection{Eigen fout of toedoen van het slachtoffer}

5I. De pluraliteit van oorzaken kan ook slaan op een samenloop van een fout van de dader en van een eigen fout of toedoen van het slachtoffer.

De eigen fout van het slachtoffer kan tot de eigen schade van het slachtoffer hebben bijgedragen. Zo kan bv. een autobestuurder uit onachtzaamheid door het rood licht rijden en een verkeersongeval veroorzaken, maar kan ook de fout van de voorranggerechtigde autobestuurder geen veiligheidsgordel te dragen waardoor hij uit het voertuig wordt geslingerd bijdragen tot de (ernst van de) verwondingen of zelfs van het overlijden. Toch zal de dader van het ongeval strafrechtelijk aansprakelijk kunnen worden gesteld. ${ }^{157}$ De oorzaak van het schadegeval moet immers niet exclusief zijn. Zonder de fout van de dader zou het schadegeval zich niet hebben voorgedaan en dus staat de fout van de dader op grond van de equivalentietheorie in causaal verband met de verwondingen. De samenlopende fout van het slachtoffer wist de strafrechtelijke aansprakelijkheid van de dader dus niet uit, nu zonder diens fout de schade zich niet zou hebben voorgedaan. ${ }^{158}$

Ook hier is er weer een verschilpunt tussen het strafrecht en het buitencontractueel aansprakelijkheidsrecht op te merken. In het buitencontractueel

I55 R. VERSTRAETEN, Handboek strafuordering, Antwerpen, Maklu, 20I2, II46-II47.

I56 Luik 27 januari i966, Jur.Liège I965-66, 209.

I57 Cass. II februari 2009, Arr.Cass. 2009, 482.

I58 In dezelfde zin: F. VAN VOLSEM, 'Culpa in het Belgisch strafrecht: een poging tot synthese', in Preadviezen 2012. Vereniging voor de vergelijkende studie van het recht van Belgiëen Nederland, Den Haag, Boom Juridische uitgevers, 20I2, II5-II6. 
aansprakelijkheidsrecht leidt een eigen fout van het slachtoffer in principe tot een verdeling van aansprakelijkheid. ${ }^{59}$ In het strafrecht wordt de aansprakelijkheid niet verdeeld: de eigen fout van het slachtoffer heeft geen invloed op de strafrechtelijke aansprakelijkheid van de dader. ${ }^{160}$

52. Het slachtoffer kan ook bijdragen tot de schade zonder een eigen fout te hebben begaan. De voorbeschiktheid van het slachtoffer is geen beletsel om de beklaagde strafrechtelijk aansprakelijk te stellen. ${ }^{16 \mathrm{I}}$ Het gebrek aan voorzorg of voorzichtigheid moet zoals gezegd niet de enige oorzaak van het misdrijf zijn. Het volstaat dat zonder de fout de schade zich niet zou hebben voorgedaan, zoals ze zich in concreto heeft voorgedaan. ${ }^{162}$ Zo kan een autobestuurder veroordeeld worden voor onopzettelijke doding wanneer het slachtoffer van een verkeersongeval enkel met een ribbreuk in het ziekenhuis wordt opgenomen, maar daar overlijdt als gevolg van de infectieuze complicaties die in de hand werden gewerkt door het zwakke weerstandsvermogen van het slachtoffer. Bij zijn opname in het ziekenhuis was het slachtoffer immers al aangetast door agranulocytose, een toestand die was ontstaan als gevolg van verschijnselen van sensibilisatie van het slachtoffer voor de onmiddellijk na het verkeersongeval toegediende geneesmiddelen. ${ }^{163}$

\section{De strafbare poging}

53. De overgang van de gevolgmisdrijven naar de topic van de strafbare poging lijkt een vreemde keuze te zijn. In een strafrechtelijk systeem waar het gevolg beslissend kan zijn voor de strafbaarheid, kan poging immers niet strafbaar zijn. De Belgische wetgever heeft er nochtans voor geopteerd ook gedragingen die slechts onvolledig de delictsinhoud realiseren strafbaar te stellen.

De kernbepaling betreft het artikel 5I Sw. dat bepaalt dat strafbare poging bestaat wanneer het voornemen om een misdaad of een wanbedrijf te plegen zich heeft geopenbaard door uitwendige daden die een begin van uitvoering van die misdaad of van dat wanbedrijf uitmaken en alleen ten gevolge van omstandigheden, van de wil van de dader onafhankelijk, zijn gestaakt of hun uitwerking hebben gemist.

I59 Zie T. VANSWEEVELT en B. WEYTS, Handboek Buitencontractueel Aansprakelijkheidsrecht, Antwerpen, Intersentia, 2009, 825, nr. I297 e.v.

I6o N. COLETTE-BASECQZ en N. BLAISE, 'Responsablité civile et responsabilité pénale', in Responsabilité. Traité théorique et pratique, Partie préliminaire, Livre 2, Waterloo, Kluwer, 20I2, 82, nr. I28.

I6I A. DE NAUW, Inleiding tot het bijzonder strafrecht, Mechelen, Kluwer, 20Io, 22I; J. DE HERDT, Fysiek persoonlijk geweld. Een onderzoek naar de accuraatheid en coherentie van de strafrechtelijke kwalificaties en instrumenten aangewend als reactie op fysiek interpersoonlijk geweld, Antwerpen, Intersentia, 20I4, nr. 655 .

I62 Corr. Luik 23 april 2008, T. Verz. 2009, I74.

I63 Cass. I5 oktober I973, Arr.Cass. I974, I77. 


\section{I Virtuele causaliteitstheorie}

54. Hoewel dit niet uitdrukkelijk uit de wet blijkt, is causaliteit van wezenlijk belang voor de leer van de strafbare poging. In bepaalde Franse rechtsleer wordt de term 'virtueel causaliteitsverband' in de mond genomen. ${ }^{164}$ Het betreft inderdaad een virtueel causaal verband die de gedraging relateert aan een resultaat dat had moeten plaatsgrijpen indien de gedraging van de betrokkene niet gestaakt was geworden omwille van een externe omstandigheid. Deze term moet worden onderscheiden van de noties 'reserveoorzaak of hypothetische causaliteit' die in het subhoofdstuk van de pluraliteit van oorzaken werden gebezigd. ${ }^{165}$

55. Een eerste bedenking die kan worden gemaakt, is dat de equivalentietheorie op het eerste gezicht moeilijk hanteerbaar is. ${ }^{166}$ Volgens deze theorie wordt een gedraging immers maar als oorzaak aangemerkt wanneer zonder deze gedraging het resultaat zich niet had voorgedaan zoals het zich in concreto heeft voorgedaan. Deze redenering kan strikt genomen niet worden geëxtrapoleerd, omdat bij de strafbare poging het resultaat per definitie uitblijft. ${ }^{167}$ Het staat nochtans vast dat er een causaliteitsvraagstuk ten grondslag ligt aan de strafbare poging.

56. De wet vereist vooreerst een openbaring door uitwendige daden van het crimineel voornemen een welbepaalde misdaad of wanbedrijf te plegen. Er wordt een volstrekt doorgevoerd crimineel voornemen vooropgesteld gerelateerd aan een bepaalde misdaad of wanbedrijf. ${ }^{168}$ Bovendien volstaat de aanwezigheid van een crimineel voornemen niet voor strafbaarheid, zélfs wanneer dit voornemen zou kunnen worden gelinkt aan een bepaalde misdaad of wanbedrijf. De wet schuift ook de premisse van begin van uitvoering naar voren. De wet vereist m.a.w. een causaal verband tussen het voornemen een bepaald misdrijf te plegen en de uiting van dit voornemen in uitwendige daden (lees begin van uitvoering). ${ }^{169}$ De grensbepaling tussen voorbereidingshandelingen en het begin van uitvoering zal dan ook cruciaal zijn voor de al dan niet strafbaarheid van het gedrag. ${ }^{170}$ Het dient te worden benadrukt dat er in België geen overkoepelende strafbepaling voorhanden is op grond waarvan voorbereidingshandelingen strafbaar kunnen worden gesteld, i.t.t. in Nederland waar sedert 1994 de voorbereiding van een misdrijf waarop naar de wettelijke

I64 P.-A. BON, La causalité en droit pénal, Université de Poitiers, 2006, II5 e.v. De zienswijze van deze auteur wordt onderschreven, ook voor de Belgische situatie.

I65 Randnr. 45 e.v.

I66 P.-A. BON, La causalité en droit pénal, Université de Poitiers, 2006, I2I-I22.

I67 Het dient wel te worden benadrukt dat op het vlak van de bestraffing de wetgever in uitzonderingsgevallen ervoor geopteerd heeft de poging gelijk te stellen met het voltooid misdrijf. Zo bepaalt art. 374 Sw. dat de aanranding (van de eerbaarheid) bestaat zodra er begin van uitvoering is.

I68 L. DUPONT en R. VERSTRAETEN, Handboek Belgisch strafrecht, Acco, Leuven, I990, 302.

I69 C.J. VANHOUDT en W. CALEWAERT, Belgisch strafrecht, II, Gent, Story-Scientia, I976, 358.

I70 In een aantal gevallen worden de voorbereidingshandelingen wel bestempeld als zelfstandig misdrijf, bv. het misdrijf bendevorming (art. 322 e.v. Sw.). 
omschrijving een gevangenisstraf van acht jaar of meer is gesteld strafbaar is als een soort voorstadium van de strafbare poging (art. $46 \mathrm{Sr}$.). ${ }^{17 \mathrm{I}}$

57. Volgende causaliteitsredenering (een bijgeschaafde equivalentietheorie ten behoeve van de autonomie van het strafrecht) zou o.i. in een eerste fase moeten worden gehanteerd om het al dan niet strafbaar karakter van de gedraging te evalueren.

Vooreerst moet men het misdrijf voor ogen hebben dat betrokkene beoogde te plegen. Het crimineel voornemen kan blijken uit de feiten zelf, uit bekentenissen door de betrokkene afgelegd ${ }^{172}$ of uit bepaalde omstandigheden. ${ }^{173}$ Vervolgens moet men nagaan of bij afwezigheid van de 'externe stoornis' de gedraging zou hebben geleid tot de voltrekking van het misdrijf. Men moet zich dus een aaneenschakeling van feiten inbeelden in afwezigheid van de externe omstandigheid. Vervolgens moet de vraag worden gesteld of dit resultaat zich ook zou hebben voorgedaan zonder de gedraging van de betrokkene. Wanneer het antwoord op deze toets positief is, kan men ervan uitgaan dat er een virtueel causaal verband bestaat tussen de gedraging die gestaakt werd omwille van een externe omstandigheid en het geprojecteerde resultaat.

Bon geeft het volgende voorbeeld. ${ }^{174} \mathrm{X}$ wil Y dodelijk treffen met een vuurwapen; $\mathrm{Z}$ komt echter op tijd tussen. Als $\mathrm{Z}$ niet was tussengekomen, zou Y geraakt zijn geweest. In afwezigheid van de handeling van $\mathrm{X}$ zou Y ook niet overleden zijn. Er is m.a.w. een causaal verband tussen de handeling van $\mathrm{X}$ en het beoogde overlijden van $\mathrm{Y}$.

Het dient te worden benadrukt dat deze redenering lichtjes afwijkt van de equivalentietheorie. In het raam van de theorie van de denkbeeldige oorzaak werd immers benadrukt dat de rechter moet vaststellen of de schade zoals zij zich in concreto heeft voorgedaan, zich al dan niet zonder de fout zou hebben gerealiseerd. De loutere vaststelling dat de schade zich ook zonder de fout had kunnen voordoen, is in beginsel van geen tel. ${ }^{175}$

I7I Voor een recente toepassing zie HR 27 mei 20I4, NJ 20I4, 4283, noot N. ROZEMOND.

I72 Hoewel waakzaamheid geboden is voor het afleggen van zogenoemde valse bekentenissen. Zie de rechtspsychologische literatuur, bv. H. ISRAËLS en R. HORSELENBERG, 'Valse bekentenissen', in P.J. VAN KOPPEN, H. MERCKELBACH, M. JELICIC en J.W. DE KEIJSER (eds.), Reizen met mijn rechter. Psychologie van het recht, Deventer, Kluwer, 2010, 765 e.v.

I73 G. BELTJENS, Encyclopédie du droit criminel belge, I, Brussel, Bruylant, I9oI, 62, nr. 5; C.J. VANHOUDT en W. CALEWAERT, Belgisch strafrecht, II, Gent, Story-Scientia, I976, 355; D. KIGANAHÉ, 'Réflexions autour du "commencement" de la tentative punissable en droit pénal', in Y. POULLET en H. VUYE (eds.), Liber Amicorum Jean du Jardin, Antwerpen, Kluwer, 200I, 22I.

I74 P.-A. BON, La causalité en droit pénal, Université de Poitiers, 2006, 122.

I75 Randnr. 44. 


\subsection{Causaliteit bij begin van uitvoering}

58. De moeilijkheid ligt hem vooral in de invulling van de notie 'begin van uitvoering' waar er ook een causaliteitsprobleem zal moeten worden ontrafeld. De hierboven beschreven virtuele causaliteitstheorie laat toe de gestelde handeling te linken aan het beoogde misdrijf, maar kan op zich niet worden gebezigd om de voorbereidingshandelingen te onderscheiden van de handelingen die een begin van uitvoering uitmaken. Hiertoe zal een andere redenering moeten worden ontwikkeld.

Volgens het Hof van Cassatie ${ }^{176}$ staat de notie begin van uitvoering in een noodzakelijk verband met het misdadig opzet van de dader en kan het slechts worden verklaard uit diens wil om een welbepaald misdrijf te plegen dat rechtstreeks en onmiddellijk wordt beoogd door de gestelde daden. Een daad die geen enkele twijfel laat bestaan over de bedoeling van de dader kan dus volgens het Hof het begin van uitvoering uitmaken dat de strafbare poging kenmerkt. Deze rechtspraak is gestoeld op de zogenoemde theorie van de 'univocité circonstantielle' van Constant. ${ }^{177}$

Door het begin van uitvoering als volgt te omschrijven en dus enerzijds te focussen op de rechtstreekse en onmiddellijke oorzaken en anderzijds op de handelingen die ondubbelzinnig strekken tot het plegen van een bepaald misdrijf, maken de heersende rechtspraak en rechtsleer ${ }^{178}$ als het ware een selectie binnen het geheel van de conditio sine qua non-oorzaken die tot het resultaat (lees het plegen van het misdrijf) hadden kunnen leiden. Handelingen die op het eerste gezicht niet onmiddellijk tot een resultaat zouden leiden en onvoorzienbare oorzaken vallen buiten boord. Dit impliceert m.a.w. dat de equivalentietheorie deels aan banden werd gelegd. ${ }^{179}$

Deze benadering doet verdacht veel denken aan de causaliteitstheorie van de rechtstreekse en onmiddellijke gevolgen die nochtans in het aansprakelijkheidsrecht in de ogen van het Hof van Cassatie geen genade vindt, omdat deze strijdig is met de equivalentietheorie. ${ }^{\mathrm{I} 0}$ Ook doet de omschrijving dat de daad geen enkele twijfel mag laten bestaan over de bedoeling van de dader denken aan een voorzienbaarheids-

I76 Cass. 3 november 2004, RW 2005-2006, I583. Zie ook bv. Corr. Luik 20 januari I983, JL I983, I70.

I77 J. CONSTANT, Traité de droit pénal, I, Luik, Impremeries Nationales, I965, nr. I88.

I78 Zie in dit verband o.m. H. BEKAERT, Handboek voor studie en praktijk van het Belgisch strafrecht, Antwerpen, Uitgeverij Ontwikkeling Antwerpen, I965, I97; W. CALEWAERT, 'De strafbare poging', Rechtskundig tijdschrift voor België I954, 226-227; W. CALEWAERT, Preadvies over strafbare poging in het Belgische recht (Vereniging voor de vergelijkende studie van het recht van België en Nederland, Zwolle, Tjeenk Willink, I970, 25; A. DE NAUW, Strafbaarheid van voorbereidingshandelingen. Preadvies voor de Vereniging voor de vergelijkende studie van het recht van België en Nederland, Zwolle-Antwerpen, Tjeenk Willink - De Sikkel, I982, 89 (die nochtans een wijziging van de pogingsbepaling onderschrijft in het raam van ernstige delicten omwille van de gevaren die de zware criminaliteit met zich kan meebrengen); L. DUPONT en R. VERSTRAETEN, Handboek Belgisch strafrecht, Acco, Leuven, I99o, 305; C.J. VANHOUDT en W. CALEWAERT, Belgisch strafrecht, II, Gent, Story-Scientia, 1976, 363.

179 Zie ook naar Frans recht: P.-A. BON, La causalité en droit pénal, Université de Poitiers, 2006, I23I24.

I8o Randnrs. I3 t.e.m. I6. 
criterium wat dan weer strookt met de adequatietheorie. ${ }^{18 \mathrm{I}}$ De vraag rijst of een dergelijke benadering wel te verkiezen valt. Het is twijfelachtig. Zoals reeds geschreven leidt de adequatietheorie omwille van haar vaagheid tot willekeur en dit omdat het in de praktijk moeilijk te achterhalen is wat wel en wat niet als een voorzienbaar gevolg kan worden gecatalogeerd. Het betreft een subjectieve theorie vertrekkende vanuit het gezichtspunt van de schadeverwekker waardoor fout en causaal verband met elkaar worden verward.

Het vereiste van een rechtstreeks en onmiddellijk verband staat dan ook haaks op de equivalentietheorie en kan niet worden bijgevallen. Volgens de equivalentietheorie kan een schadeverwekker immers ook aansprakelijk zijn voor abnormale, niet-noodzakelijke of onvoorzienbare gevolgen van zijn fout of andere aansprakelijkheidsgrond waarvoor hij instaat. ${ }^{182}$ Het is nochtans niet nodig de termen 'rechtstreeks en onmiddellijk' verband als premisse naar voren te schuiven bij de strafbare poging.

Het dient trouwens te worden benadrukt dat de rechtspraak zelf niet altijd consequent is, bv. in het raam van de diefstal. ${ }^{183}$ Zo is er rechtspraak die bepaalt dat diegene die alvorens de kassa te passeren die zaken die hij voornemens was te stelen, teruglegt niet strafbaar is (noch als voltooid misdrijf noch als poging), omdat de diefstal slechts geacht wordt voltrokken te zijn van zodra men voorbij de kassa is en het niet uitgesloten is dat hij de goederen terugplaatst of betaalt. ${ }^{184}$ Volgens andere rechtspraak maakt het afbreken van diefstalbeveiligingsplaatjes echter wel een begin van uitvoering uit zonder dat tevens vereist is dat de kassa wordt voorbijgegaan zonder te betalen. ${ }^{185}$ Het 's nachts binnendringen in een landgoed en er in de buurt inbrekersmateriaal klaarleggen, werd eveneens aangemerkt als een begin van uitvoering. ${ }^{186}$

59. Een andere redenering moet o.i. worden verkozen boven de eerder subjectieve benadering en soms wispelturige invulling door de jurisprudentie van de pogingsleer. De rechtspraak van het Hof van Cassatie stelt voorop dat de gestelde handeling geen twijfel mag laten bestaan over de bedoeling van de dader. Deze zekerheid kan evenwel nooit worden gegarandeerd. Wanneer A een mes manipuleert op weg naar B en de handeling omwille van een externe omstandigheid wordt gestaakt, kan nooit met zekerheid worden achterhaald of er nu sprake is geweest van een poging tot moord, van een poging tot opzettelijke slagen of verwondingen dan wel van een loutere bedreiging. ${ }^{187}$ Wanneer de materialiteit van de feiten op zich niet volstaat om met een gerechtelijke zekerheid de link te leggen met een welbepaald beoogd

\footnotetext{
I8I Randnrs. 9 en Io.

I82 Randnr. 7.

I83 Zie ook A. DE NAUW, Inleiding tot het bijzonder strafrecht, Antwerpen, Kluwer, 2010, 313-3I4.

I84 Corr. Luik I5 juni I98I, Jur.Liège I98I, 280; Corr. Veurne 5 september 2006, NC 2008, 370.

I85 Corr. Tongeren 8 november I996, RW I998-99, 409, noot M. GELDERS.

I86 Cass. 24 maart 2010, Pas. 2010, 983.

I87 P.-A. BON, La causalité en droit pénal, Université de Poitiers, 2006, I24.
} 
misdrijf, kan de door de jurisprudentie voorgeschreven premisse van rechtstreeks en onmiddellijk verband bijna per definitie nooit worden vervuld. Wanneer er twijfel bestaat omtrent het crimineel voornemen kan men niet anders dan slechts het voltooid misdrijf te bestraffen. ${ }^{188}$ In het hierboven aangehaalde voorbeeld betreft dit dan de bedreiging. Hetzelfde geldt voor de persoon die wordt vervolgd voor vernieling van afsluitingen (art. 545 Sw.). Onzeker is het immers of deze persoon de bedoeling had om zich door de vernieling van de afsluiting een toegang tot de woning wilde verschaffen om er iemand te doden, om er te stelen of om er brand te stichten. ${ }^{189}$

De huidige rechtspraak van feitenrechters schippert soms tussen een objectieve benadering $^{190}$ en een subjectieve invulling van de pogingsleer ${ }^{191} z o n d e r$ dat er altijd een rode draad kan worden ontwaard.

6o. Het in de geest trachten te kruipen van betrokkene voor de toetsing van de voorwaarde van het 'begin van uitvoering' is niet nodig en maakt de leer van de strafbare poging alleen maar onnodig complex. De wet geeft hiertoe ook geen enkele indicatie. Artikel 5I Sw. focust wel degelijk op de gedraging, wat aansluit bij de objectieve pogingsleer waar niet de gebleken intentie maar wel de begonnen delictsvervulling het aanknopingspunt is. Wat men bijgevolg dient te achterhalen, is of de gestelde handeling normalerwijze tot de voltrekking van het misdrijf zou hebben geleid. Het betreft een toetsing in abstracto met als referentiepunt een neutrale persoon en niet de schadeverwekker zelf.

Dit uitgangspunt congrueert niet helemaal met de equivalentietheorie, maar is o.i. nodig ten behoeve van de autonomie van het strafrecht om rechtsonzekerheid en dus willekeur te vermijden. ${ }^{192}$ Deze benadering is ook niet gelijk te stellen met een zuiver objectieve pogingsleer, nu volgens een strikt objectieve benadering de uitvoe-

I88 Zie ook J.J. HAUS, Principes généraux du droit pénal belge, I, Gent, Librairie Générale de adv. Hoste, I879, 328, nr. 435; A. LORENT, 'L'élément moral de la tentative de meurtre', RRD 2007, 333-334.

I89 L. DUPONT en R. VERSTRAETEN, Handboek Belgisch strafrecht, Acco, Leuven, I990, 303.

I9o Zo is er geen poging tot diefstal wanneer de gauwdief zijn hand steekt in een lege zak (Brussel I9 september I899, Pas. I898, II, I3; Corr. Brussel 30 juni I983, RW 1983-84, 2177, noot A. DE NAUW). Wanneer het bewijs van de bedoeling om te stelen niet is geleverd, maakt het feit een etalageruit in te slaan en er een barst in te maken evenmin een poging tot diefstal uit (Corr. Verviers 29 april I997, JLMB I997, I46I).

I9I Bv. poging tot diefstal bij een toevallig lege brandkast (Mil. Ger. 23 oktober ig68, Rev.dr.pén. I969-70, 508). Zo ook pleegt volgens de rechtspraak een poging tot diefstal hij die teneinde zich meester te maken van geld dat gewoonlijk is opgeborgen in een lessenaar deze lessenaar openbreekt en er niets in vindt omdat het er kort tevoren werd uitgenomen (Kr. Henegouwen 8 maart I907, Rev.dr.pén. I907, 338). Zie nochtans Gent 4 mei I948 (RW I948-49, I42) waar werd geoordeeld dat poging onmogelijk is wanneer het voorwerp dat de dader bedoelt weg te nemen zich niet ter plaatse bevindt waar hij het meende het te zullen vinden.

I92 Zie ook D. KIGANAHÉ, "Réflexions autour du "commencement" de la tentative punissable en droit pénal', in Y. POULLET en H. VUYE (eds.), Liber Amicorum Jean du Jardin, Antwerpen, Kluwer, 200I, 236 en 238: 'La prise en compte de façon privilégiée de l'élément intentionnel dans l'appréciation du point de départ de la tentative punissable assure bien la protection de la société par une répression efficace, mais peut conduire à des abus si elle n'est pas accompagnée par la considération du critère objectif' en 'Il y $a$ un risque d'atteindre des actes qui objectivement ne portent pas atteinte à l'ordre public et n'établissent pas 
ringshandeling niet meer losstaat van het misdrijf waardoor er een aanvang moet gemaakt zijn met een van de wettelijke bestanddelen van het misdrijf. M.b.t. diefstal zou dit impliceren dat er slechts sprake kan zijn van strafbare poging wanneer met de wegneming een aanvang werd gemaakt. ${ }^{193}$ Zo ver willen wij niet gaan, daar de figuur van de dader bij de invulling van de notie 'begin van uitvoering' nog zijn betekenis heeft, evenwel in de gedaante van een neutrale persoon. In de Franse literatuur makkt men in dit verband gewag van de zogenoemde 'observateur extérieur'. ${ }^{194}$ Aan de feitenconstellatie zelf mag in de redenering niet worden getornd. Net zoals bij de theorie van het rechtmatig alternatief ${ }^{195}$ moet de reconstructie van het schadeverhaal gebeuren a.d.h.v. dezelfde concrete feiten. Een dergelijke redenering sluit dan bv. uit dat er sprake kan zijn van strafbare poging tot moord wanneer het gehanteerde vuurwapen ongeladen was of wanneer er een te grote afstand was tussen de dader en het slachtoffer, ${ }^{196}$ daar in deze gevallen deze handelingen door wie deze ook zouden gesteld zijn geweest nooit tot een gewenst resultaat hadden kunnen leiden. De hypothese van de dader die het slachtoffer niet heeft kunnen raken omwille van een eigen onhandige manipulatie van het wapen, valt dan wel weer onder de actieradius van de strafbare poging tot moord. In normale omstandigheden had deze handeling gepleegd door de 'observateur extérieur' immers wel tot het overlijden van het slachtoffer geleid.

6r. Het gevolg van een dergelijke benadering van de strafbare poging is dat mogelijkerwijs de strafbaarheid van de relatief ondeugdelijke poging strenger zal moeten worden beoordeeld. Volgens het Hof van Cassatie ${ }^{197}$ is een absoluut ondeugdelijke poging een poging die gelet op het beoogde voorwerp of het aangewende middel in geen enkel geval tot een voltrokken misdrijf kan leiden. Een absoluut ondeugdelijke poging is daarom niet strafbaar. Een relatief ondeugdelijke poging is een poging die mislukt wegens toevallige omstandigheden en is volgens het Hof wél strafbaar. Aan deze uitgangspunten willen wij niet tornen, daar zij in overeenstemming kunnen worden gebracht met de nieuwe benaderingswijze van de strafbare poging. Rechtspraak ${ }^{198}$ die bepaalt dat er sprake is van een strafbare poging wanneer een verdachte gepoogd had een hoeveelheid heroïne of morfine in zijn bezit te krijgen, doch slechts een wit poeder ontving dat geen verdovend middel was, kan evenwel niet langer overeind blijven. Ook de rechtspraak die een strafbare poging ziet in de dief die zijn hand in een lege brandkast steekt of een strafbare poging tot vergiftiging wanneer een te geringe dosis arsenicum wordt toegediend, wordt bediscussieerbaar in het licht van de nieuwe theorie.

avec certitude dans le chef du prévenu la volonté de commettre le crime pour la tentative duquel il est poursuivi. Cette conception peut conduire à des décisions critiquables.'

I93 A. DE NAUW, Strafbaarheid van voorbereidingshandelingen. Preadvies voor de Vereniging voor de vergelijkende studie van het recht van België en Nederland, Zwolle-Antwerpen, Tjeenk Willink - De Sikkel, I982, 2.

I94 P.-A. BON, La causalité en droit pénal, Université de Poitiers, 2006, I29-I30.

I95 Zie randnr. 25.

I96 P.-A. BON, La causalité en droit pénal, Université de Poitiers, 2006, I28.

I97 Cass. 8 april 20I4, A.R.P.I3.20I8.N.

I98 Corr. Brussel zo juni I983, RW I983-84, 2 I77 met kritische noot A. DE NAUW. 
62. Volledigheidshalve dient te worden benadrukt dat de vooropgestelde bijgeschaafde equivalentietheorie in het raam van het leerstuk van de poging soms definitief zal moeten worden verlaten. In bepaalde gevallen zal het causaliteitsvraagstuk niet aan de orde zijn. Het is immers een bewuste keuze geweest van de wetgever enkel de poging tot een misdaad altijd strafbaar te stellen. De poging tot wanbedrijf is alleen strafbaar in de gevallen bij wet voorzien en de poging tot overtreding is in beginsel niet strafbaar (art. 52-53 Sw.). De achterliggende reden moet in de subsidiariteitstoets worden gezien. Er wordt vooropgesteld dat bestraffing van de strafbare poging noodzakelijk moet zijn voor de beveiliging van de sociale orde en nuttig in haar gevolgen. ${ }^{199}$

\section{Causaliteit in het strafrecht: de dader}

63. Het strafrecht gaat uit van het postulaat van de wilsvrijheid. Op het eerste gezicht moet er op dit niveau al een causaliteitsvraagstuk worden ontwaard. Een wilsvrijheid die losstaat van eerder veroorzaakte gebeurtenissen of invloeden kan geen 'wil' zijn. De wil kan bezwaarlijk zijn eigen oorzaak zijn. De wilsvrijheid moet evenwel als een onmisbaar normatief uitgangspunt in het strafrecht worden beschouwd. ${ }^{200}$

Een misdrijf is een gedraging die nochtans wel aan het betrokken rechtssubject moet worden toegerekend. De toerekening aan de dader wordt in de literatuur beschouwd als een groot causaliteitskluwen. Toerekenen impliceert immers het leggen van een causaal verband tussen dader en misdrijf. ${ }^{201}$ M.b.t. het misdrijf zelf moet de menselijke gedraging (materieel bestanddeel) worden gelinkt aan de vereiste schuldvorm (moreel bestanddeel). Het daderschap zelf impliceert het leggen van een causaal verband tussen de strafbare gedraging en één of meerdere personen voor zover de gedraging verweten kan worden aan de betrokkene(n). ${ }^{202}$ Het zou ons echter te ver leiden al deze aspecten onder de loep te nemen. In dit hoofdstuk wordt ervoor geopteerd te focussen op de problematieken van enerzijds de strafbare deelneming en anderzijds van de geestesgestoorde delinquent.

\section{De strafbare deelneming}

64. Dankzij de regels inzake de strafbare deelneming (art. 66 e.v. Sw.) kan niet alleen de dader strafrechtelijk worden aangesproken doordat hij alle bestanddelen

I99 F. VERBRUGGEN, 'Strafbare voorbereidinghandelingen in België: een autopsie zonder lijk', in Voorbereidingshandelingen in het strafrecht (preadviezen voor de Nederlands-Vlaamse Vereniging voor Strafrecht), Nijmegen, Wolf Legal Publishers, 2004, 3 I.

200 D. ROEF, 'Hoeveel wilsvrijheid heeft het strafrecht nodig? Over de (on)verenigbaarheid van strafrechtelijke verantwoordelijkheid en neurowetenschap', in F. DERUYCK en M. ROZIE (eds.), Het strafrecht bedreven. Liber amicorum Alain De Nauw, Brugge, die Keure, 2011, 7I3 en 730.

201 R. LEGROS, Voorontwerp van strafwetboek, Brussel, Uitgave van het Belgisch Staatsblad, I985, I3I.

202 P. WAETERINCKX, De strafrechtelijke verantwoordelijkheid van de rechtspersoon en zijn leidinggevenden, Antwerpen, Intersentia, 20II, 4 e.v. 
zelf heeft vervuld, maar kunnen ook anderen die op een bepaalde manier bij het misdrijf betrokken zijn, strafbaar worden bevonden.

Hoewel dit nergens in de wet uitdrukkelijk wordt gestipuleerd, betreft de topic van de strafbare deelneming één groot causaliteitsgebeuren. Het is immers maar wanneer er een causaal verband kan worden ontwaard dat de strafrechtelijke aansprakelijkheid van de deelnemer in het vizier komt. In deze afdeling zal alleen worden gefocust op de causaliteitsproblemen. Een volledige analyse van de strafbare deelneming valt buiten het bestek van deze bijdrage. ${ }^{203}$

\section{I.I Een gelaagde causaliteitsredenering ${ }^{204}$}

65. Om na te gaan of er sprake is van strafbare deelneming, moet er een gelaagde causaliteitsredenering worden toegepast.

Ten eerste ontleent de deelneming zijn strafbaar karakter slechts aan het hoofdfeit. De deelneming is slechts strafbaar indien het misdrijf waaraan men een bijdrage heeft willen leveren daadwerkelijk werd gepleegd of in het stadium van de strafbare poging is blijven steken. Zonder link met het hoofdfeit is er m.a.w. geen strafrechtelijke aansprakelijkheid van de deelnemer. ${ }^{205}$ Dit principe wordt de accessoriteit of de onzelfstandigheid van de strafbare deelneming genoemd. Het gaat wel degelijk om een verband tussen het hoofdfeit en de deelnemingshandeling; tussen de hoofddader en deelnemer moet er op zich geen verband bestaan. Zo zal de deelnemer bv. nog kunnen worden aangesproken wanneer de hoofddader overleden is. Het vereiste van verband tussen hoofdfeit en deelnemingshandeling krijgt verder vorm bij de invulling van de tweede voorwaarde.

Ten tweede volstaat het niet dat er een hoofdfeit werd gepleegd waaraan een willekeurige deelnemingshandeling kan worden verbonden. Het is wel degelijk in de aard zelf van de deelnemingshandeling dat het causaal verband moet worden gezocht. In de daden van deelneming moeten evenwel niet alle bestanddelen van het misdrijf aanwezig zijn. ${ }^{206}$

Deelneming aan een misdrijf (misdaad of wanbedrijf) kan verschillende vormen aannemen. Er wordt een onderscheid gemaakt tussen (mede)daderschap (art. 66 Sw.) en medeplichtigheid (art. 67 Sw.). De tweedeling is belangrijk op het niveau van de bestraffing (art. 69 Sw.).

In beide categorieën maakt de wet nog een onderscheid tussen materiële en morele deelnemers naar gelang van de aard van de deelneming. De uitvoering en rechtstreekse medewerking aan de uitvoering van een misdaad of wanbedrijf zijn vormen van materieel daderschap (art. 66 lid 2 Sw.), zoals dit ook het geval is voor de noodzakelijke medehulp of bijstand (art. 66 lid 3 Sw.). De individuele aanzetting

203 Voor een standaardwerk zie J. VANHEULE, Strafbare deelneming, Antwerpen, Intersentia, 20Io, I049 p. Zie ook J. D'HAENENS, Strafbare deelneming in APR, Gent, Story-Scientia, I959, I32 p.

204 Zie ook naar Frans recht waar een gelaagde causaliteitsredenering wordt vooropgesteld: P.-A. BON, La causalité en droit pénal, Université de Poitiers, 2006, 8I e.v.; P. SALVAGE, 'Le lien de causalité en matière de complicité', Rev.sc.crim. I98I, 25-42.

205 Voor een toepassing zie bv. Cass. I8 januari 2000, Arr.Cass. 2000, 4I.

206 Cass. 5 oktober 2005, A.R. P.05.0444.F. 
(art. 66 lid 4 Sw.) en de openbare aanzetting (art. 66 lid 5 Sw.) zijn dan weer vormen van moreel daderschap. De wet maakt geen onderscheid tussen de dader en de mededader; beide begrippen worden geacht dezelfde betekenis te hebben. ${ }^{207}$ Het geven van onderrichtingen die dienstig zijn om de misdaad of het wanbedrijf te plegen (art. 67 lid 2 Sw.) betreft een vorm van morele medeplichtigheid, terwijl het verschaffen van wapens, werktuigen of enig ander middel om een misdaad of een wanbedrijf te plegen (art. 67 lid 3 Sw.) een vorm van materiële medeplichtigheid oplevert, net als de nuttige hulp of bijstand (art. 67 lid 4 Sw.).

Hoewel de deelnemingsvormen wettelijk worden omschreven, is het beslissend onderscheidingscriterium tussen mededaderschap en medeplichtigheid volgens de rechtspraak wel degelijk het gegeven of de verleende hulp noodzakelijk, dan wel nuttig was.

Ten derde moet betrokkene hebben geweten dat hij deelnam aan een bepaalde misdaad of bepaald wanbedrijf. Als uitgangspunt geldt dat indien betrokkene een ander misdrijf pleegt dan datgene waaromtrent wilsovereenstemming bestond, de band die normaal door kennis en opzet tussen de deelnemingshandeling en het misdrijf gelegd wordt, verbroken is. ${ }^{208}$ Het bewust niet willen weten sluit deelneming evenwel niet uit. ${ }^{209}$ Ook is niet vereist dat het voorafgaand overleg tussen betrokkenen wordt bewezen. ${ }^{210}$ De deelnemer moet bovendien geen kennis hebben gehad van alle aan het misdrijf gerelateerde elementen. ${ }^{21}$ In het geval van feitelijke discongruentie met de modus operandi valt nochtans niet uit te sluiten dat de vereiste band tussen de deelnemingshandeling en het hoofdfeit in het gedrang komt. ${ }^{212}$

Het is slechts wanneer deze drie voorwaarden cumulatief vervuld zijn, dat er van strafbare deelneming kan worden gesproken. Als er geen strafbare deelneming is, kan er niettemin toch sprake zijn van strafbaarheid omdat de zogenoemde deelnemingshandeling op zich misschien een misdrijf kan opleveren. Het verschaffen van een wapen zou bv. dan als verboden wapenbezit kunnen worden aangemerkt.

\section{I.2 Toepassing van de equivalentieleer en kritiek op het huidig systeem van de deelneming}

66. In de voorwaarden tot strafbare deelneming moet een toepassing van de equivalentieleer worden gezien.

Elke deelnemer moet immers worden beschouwd als diegene die een conditio sine qua non-voorwaarde heeft toegevoegd aan het eindresultaat. ${ }^{213}$ Het misdrijf zoals het werd gepleegd, zou m.a.w. nooit op dezelfde wijze tot stand gekomen zijn wanneer er geen sprake zou geweest zijn van een deelnemingshandeling. Zonder deelneming

207 Zie bv. Cass. 5 oktober 2005, A.R.P.05.0444.F.

208 C.J. VANHOUDT en W. CALEWAERT, Belgisch strafrecht, II, Gent, Story-Scientia, I976, 6or. Toch gelden er temperingen op dit uitgangspunt.

209 Cass. I6 december 2003, A.R. P.03.0452.N; Cass. 2 I juni 2007, A.R. I285 P. 2006.

2 Io Cass. 5 oktober 2005, A.R. P.05.0444.F.

2 II Zie bv. Cass. I8 mei I993, RW I994-95, 359; Cass. 7 september 2009, A.R. P. 05.0348.F; Cass. I7 april 20I3, A.R. P.I3.0I48.F.

2 I2 J. VANHEULE, 'Strafbare deelneming: een overzicht van rechtspraak (2000-20I0)', NC 20I2, I4.

2I3 P.-A. BON, La causalité en droit pénal, Université de Poitiers, 2006, 89. 
zou het misdrijf niet zijn gepleegd zoals het in concreto werd gepleegd. A contrario betekent dit dat wanneer het hoofdfeit zich op identieke wijze zou hebben voorgedaan zonder tussenkomst van anderen, er geen sprake kan zijn van strafbare deelneming.

67. De equivalentieleer indachtig lijkt het daarom vreemd een onderscheid te moeten maken tussen mededaderschap en medeplichtigheid. Of de hulp nu noodzakelijk dan wel nuttig was, in beide gevallen heeft de deelnemingshandeling een stempel gedrukt op het uiteindelijke misdrijf. Medeplichtigen zijn m.a.w. niet te reduceren tot 'randfiguren'214 of 'onrechtstreekse deelnemers' ${ }^{215}$ en 'hebben niet slechts een conditioneel aandeel in het misdrijf', ${ }^{216}$ maar hebben net zoals de mededaders een volwaardig aandeel in de causaliteitsketen gehad. Elke deelnemer moet als een equivalente oorzaak van het misdrijf worden beschouwd. De equivalentieleer maakt geen gradatie in de oorzaken: ofwel is een deelnemingshandeling oorzaak ofwel niet. ${ }^{217}$ Ook wanneer de hulp zogenaamd slechts nuttig was maar niet noodzakelijk zou het misdrijf niet zijn gepleegd zoals het in concreto werd gepleegd.

De in een recent arrest van 25 april $2012^{218}$ door het Hof van Cassatie gemaakte tweedeling tussen hoofd- en bijkomstige deelneming kan dan ook niet worden onderschreven. Volgens het Hof van Cassatie worden zij die schuldig zijn aan hoofddeelneming daders van het misdrijf genoemd. Zij liggen aan de oorzaak van het misdrijf. Zij die schuldig zijn aan bijkomstige deelneming worden medeplichtigen genoemd: hun tussenkomst was nuttig doch niet noodzakelijk voor het stellen van de daad. ${ }^{219}$

Zoals reeds geschreven strookt deze zienswijze niet met de equivalentieleer. Het zijn niet alleen de (mede)daders die de oorzaak zijn van het misdrijf. Daarom ook kan de oudere rechtspraak van het Hof van Cassatie niet worden bijgevallen. ${ }^{220} \mathrm{Op}$ grond van deze rechtspraak moeten als (mede)daders worden beschouwd allen die door hun persoonlijke handelingen aan de uitvoering van het als misdrijf bestempelde feit rechtstreeks hebben meegewerkt op zodanige wijze dat zonder hun deelneming het misdrijf niet zou zijn gepleegd zoals het gepleegd werd. Het dient te worden benadrukt dat volgens de equivalentieleer het onderscheid tussen rechtstreekse en onrechtstreekse oorzaken niet wordt gemaakt.

68. De vraag rijst dan ook of de tweedeling tussen mededaderschap en medeplichtigheid wetenschappelijk gefundeerd is waardoor een afwijking van de equivalentietheorie niettemin op zijn plaats is.

2 I4 W. NIEBOER, Schets materieel strafrecht, Arnhem, Gouda Quint, I99I, 20I e.v.

2 I5 Rk. Neufchâteau I7 januari 2003, JT $2003,87$.

$2 \mathrm{I} 6$ G.A.M. STRIJARDS, Hoofdstukken van materieel strafrecht, Utrecht, Lemma, I992, I76-I77.

2 I7 J. VANHEULE, Strafbare deelneming, Antwerpen, Intersentia, 2010, 234.

218 Cass. 25 april 20I2, RABG 2013, I039 met kritische noot J. VANHEULE; T.Strafr. 2013, 299, noot B. MEGANCK.

2I9 Deze zienswijze werd eerder al verwoord door Haus, een van de geestelijke vaders van het Strafwetboek (J.J. HAUS, Principes généraux du droit pénal belge, I, Gent, Librairie de Ad. Hoste, I874, 358).

220 Cass. 6 november ig67, Arr.Cass. I968, 339. 
Over het al dan niet noodzakelijk karakter van de geboden hulp of bijstand oordeelt de strafrechter op onaantastbare wijze. ${ }^{221}$ Een algemeen geldende maatstaf om praktisch het onderscheid te maken, is ver zoek. ${ }^{22}$ Het staat nochtans vast volgens het Hof van Cassatie dat eenzelfde gedraging niet tegelijkertijd mededaderschap en medeplichtigheid kan opleveren. ${ }^{223}$ Volgens bepaalde rechtsleer is de indeling tussen mededaderschap en medeplichtigheid helemaal niet gesteund op een duidelijk wetenschappelijk criterium hetgeen in sommige gevallen het maken van een feitelijk onderscheid bemoeilijkt. ${ }^{224}$

De wetgever zelf werkt immers verwarring in de hand. De wetgever omschrijft handelingen die als medeplichtigheid, maar anderzijds ook als mededaderschap zouden kunnen worden gecatalogeerd. Het uitdrukkelijk aangeven dat het geven van onderrichtingen (art. 67 lid 2 Sw.) een vorm van medeplichtigheid uitmaakt, doet de wenkbrauwen fronsen, aangezien deze handeling afhankelijk van de omstandigheden evenzeer als mededaderschap zou kunnen worden aangemerkt. ${ }^{225}$ Dezelfde bedenking kan worden gemaakt bij het verschaffen van wapens, werktuigen of enig ander middel (art. 67 lid 3 Sw.). Ook kan uit de wettekst worden afgeleid dat de noodzakelijke medehulp van artikel 66 lid 3 Sw. en de nuttige medehulp van artikel 67 lid 4 Sw. grensgebieden zijn. ${ }^{226}$ Het is bijgevolg niet overdreven te stellen dat de redactie van de wetsartikelen m.b.t. de deelneming onevenwichtig en gebrekkig is. ${ }^{227}$

Niet alleen is de wetgeving onscherp, maar als gevolg hiervan blaast ook de rechtspraak warm en koud tegelijk, waardoor het dikwijls een onmogelijke opdracht wordt de tweedeling mededaderschap en medeplichtigheid te maken. Een aantal voorbeelden maakt duidelijk dat de jurisprudentie niet altijd ophelderend is. Zo is volgens het Hof van Cassatie relatief noodzakelijke hulp gelijk te stellen met noodzakelijke hulp in de zin van artikel 66 lid 3 Sw. ${ }^{228}$ het maakt zelfs niet uit of de noodzakelijke hulp klein of groot is geweest. ${ }^{229}$ De vraag rijst onvermijdelijk of nuttige hulp dan ook niet als relatief noodzakelijke hulp kan worden beschouwd en of er m.a.w. nog ruimte bestaat voor de nuttige hulp of bijstand. ${ }^{23}$ Eveneens volstaat, zoals reeds geschreven, het geven van inlichtingen om van medeplichtigheid te spreken; ${ }^{231}$ een eenvoudige raad is dan weer onvoldoende. ${ }^{232}$ De verstrekte inlichtingen kunnen

22 I Cass. 3 september I9I5, Pas. I9I5-I6, I, 446; Cass. 6 oktober I947, Pas. I947, I, 403; Cass. 23 januari 1950, Pas. I950, I, 34I; Cass. 7 mei I95I, Pas. I95I, I, 599; Cass. 7 februari 1979, Rev.dr.pén. I979, 392.

222 C.J. VANHOUDT en W. CALEWAERT, Belgisch strafrecht, II, Gent, Story-Scientia, I976, 6I8.

223 Cass. 25 april 2012, RABG 2013, I039 met kritische noot J. VANHEULE; T.Strafr. 2013, 299, noot B. MEGANCK.

224 C.J. VANHOUDT en W. CALEWAERT, Belgisch strafrecht, II, Gent, Story-Scientia, I976, 602.

225 J. D'HAENENS, Strafbare deelneming in APR, Gent, Story-Scientia, I959, 99.

226 L. DUPONT en R. VERSTRAETEN, Handboek Belgisch strafrecht, Leuven, Acco, I990, 33I.

227 C.J. VANHOUDT en W. CALEWAERT, Belgisch strafrecht, II, Gent, Story-Scientia, I976, 6I6-6I7. Zie ook J.D.M. LELIARD, 'Een wetboek herschrijven?', RW 2006-2007, II42-II48.

228 Cass. 28 september 1993, Arr.Cass. I993, 773.

229 Cass. 9 april I974, Arr.Cass. I974, 873; Cass. 2 december 1975, Arr.Cass. I976, 4I5.

230 J. VANHEULE, 'Kanttekeningen bij het gradueel onderscheid tussen daderschap en medeplichtigheid', RABG 2013, I045-I046.

23 I Cass. 25 mei 1949, Arr.Cass. 1949, 343.

232 Cass. 29 oktober 1973, Arr.Cass. 1974, 237. 
echter van zo groot belang zijn dat zij een noodzakelijke hulp zijn. ${ }^{233}$ Ook het transport of inladen van gestolen goederen werd in het verleden door de rechtspraak niet alleen aangemerkt als een vorm van medeplichtigheid (art. 67 lid 4 Sw.), ${ }^{234}$ maar ook als noodzakelijke medehulp tot uitvoering ${ }^{235}$ en zelfs als een rechtstreekse medewerking aan de uitvoering (art. 66 lid 2 Sw.). ${ }^{236}$ De vooraf verleende toezegging om mee te werken aan een misdrijf kan volgens het Hof van Cassatie een essentiële hulp voor het plegen van het misdrijf opleveren; ${ }^{237}$ a contrario wil deze rechtspraak ook zeggen dat hetzelfde uitgangspunt in een andere feitenconstellatie slechts een nuttige hulp kan uitmaken.

Het staat vast dat tussen de verschillende deelnemingsvormen de grens moeilijk te trekken is. ${ }^{238}$ Bepaalde rechtsleer waarschuwt bovendien dat een te verruimende interpretatie al te gemakkelijk willekeur in de hand kan werken. ${ }^{239}$

69. Een te bewandelen piste zou dan ook de Franse benadering kunnen zijn. In het Franse Strafwetboek wordt het onderscheid tussen mededaders en medeplichtigen immers niet gemaakt. Of de hulp of bijstand slechts nuttig dan wel noodzakelijk was, doet er niet toe. Zij worden allen als 'complices' aangemerkt. ${ }^{240} \mathrm{Al}$ zij die hebben bijgedragen op een of andere door de wet omschreven wijze zijn dus deelnemers. Deze zienswijze strookt ontegensprekelijk wél met de equivalentieleer. Het dient te worden benadrukt dat ook de Commissie voor de Herziening van het Strafwetboek onder voorzitterschap van professor Châtel en later professor D'Haenens reeds in I979 pleitbezorger was om het onderscheid tussen (mede)dader en medeplichtige op te heffen. ${ }^{241}$ In het Voorontwerp van Strafwetboek van Koninklijk Commissaris Legros van 1985 is eveneens het onderscheid tussen (mede)dader en medeplichtige verdwenen met de motivering dat de assimilatie nodig is t.a.v. een steeds meer ontwikkelde en actieve criminaliteit in vereniging/bende. ${ }^{242}$ Ook in de gezaghebbende rechtsleer gaan er stemmen op om het graduele onderscheid tussen (mede)daderschap en medeplichtigheid te verlaten. ${ }^{243}$

233 Cass. I4 mei i945, Pas. I945, I, r6o. Zie ook L. DUPONT en R. VERSTRAETEN, Handboek Belgisch strafrecht, Acco, Leuven, I990, 329.

234 Cass. I2 mei 2004, Arr.Cass. 2004, 838; Corr. Nijvel 28 januari I998, JT, I999, 737.

235 Cass. 27 oktober 2009, NC 2010, I85.

236 J. VANHEULE, 'Een aantal beginselen betreffende de deelnemingsvormen omschreven in de artikelen 66 en 67', NC 2007, I57 die verwijst naar Cass. 25 oktober I875, BJ I895, k.I534.

237 Cass. I8 januari 2000, Arr.Cass. 2000, I32.

238 Zie ook J. VANHEULE, 'Kanttekeningen bij het gradueel onderscheid tussen daderschap en medeplichtigheid', RABG 2013, I045.

239 J. D’HAENENS, Strafbare deelneming in APR, Gent, Story-Scientia, I959, 99.

240 Art. I2I-6 C.P. bepaalt: 'Sera puni comme auteur le complice de l'infraction au sens de l'article 121-7.' Art. I2I-7 C.P. bepaalt: 'Est complice d'un crime ou d'un délit la personne qui sciemment, par aide ou assistance, en a facilité la preparation ou la consommation. Est également complice la personne qui par don, promesse, menace, ordre, abus d'autorité ou de pouvoir aura provoqué à une infraction ou donné des instructions pour la commettre.'

24I Commissie voor de herziening van het Strafwetboek, Brussel, Uitgave van het Belgisch Staatsblad, I979, $45-47,61-63,66-67$ en 96.

242 R. LEGROS, Voorontwerp van Strafwetboek, Brussel, Uitgave van het Belgisch Staatsblad,I985, I5I.

243 J. VANHEULE, 'Kanttekeningen bij het gradueel onderscheid tussen daderschap en medeplichtigheid', RABG 2013, I052. Voor een nieuwe benadering van de strafbare deelneming zie het 
70. Een volledige assimilatie tussen (mede)daders en medeplichtigen kan evenwel ongewenste gevolgen met zich meebrengen waardoor een bijsturing op grond van de autonomie van het strafrecht aangewezen is.

In de eerste plaats moet de individualisering van de bestraffing op het niveau van de straftoemeting hoog in het vaandel worden gedragen, maar ook dient men oog te hebben voor het vraagstuk van de al dan niet doorwerking van de verzwarende omstandigheden die eigen zijn aan een bepaald strafbaar feit. Het dient te worden benadrukt dat bij de aanwezigheid van verzwarende omstandigheden de strafverzwaring al in de wet zelf wordt ingecalculeerd. In vergelijking met het basismisdrijf kan het zijn dat door de aanwezigheid van verzwarende omstandigheden de minimum- en/of maximumstraf wordt opgetrokken. Het wegvallen van de verzwarende omstandigheid ontneemt het feit zijn strafbaar karakter niet; men valt alleen terug op de wettelijke bestraffing van het basismisdrijf. Bij de subjectieve verzwarende omstandigheden is er geen probleem, daar zij betrekking hebben op de persoon van de dader en enkel van toepassing kunnen zijn op de dader of de deelnemer die het desbetreffende kenmerk vertoont (bv. art. 464 Sw.: loondienaar bij diefstal). De objectieve of materiële of reële verzwarende omstandigheden zijn niet eigen aan de dader doch wel inherent aan het misdrijf. Ze hebben betrekking op de omstandigheden waarin de feiten worden gepleegd, de gebruikte middelen, de gevolgen of de hoedanigheid van het slachtoffer. ${ }^{244}$ De Göktepe-rechtspraak van het Europees Hof voor de Rechten van de Mens $^{245}$ luidens dewelke de automatische toerekening van verzwarende omstandigheden (in casu de doodslag bij diefstal in het raam van artikel 475 Sw.) aan alle deelnemers aan het hoofdfeit, ondanks verzoek tot individualisering, strijdig werd bevonden met artikel 6 EVRM, blijkt niet altijd de nodige omwentelingen te hebben teweeggebracht in de Belgische rechtspraktijk. ${ }^{246}$ De toepassing van objectieve verzwarende omstandigheden moet nochtans altijd worden gerelateerd aan de persoonlijke betrokkenheid van de deelnemers. Het deelnemingsvraagstuk moet immers worden voorgesteld als een pluraliteit van oorzaken waarbij voor elke fout afzonderlijk het conditio sine qua non-verband met de schade moet worden afgetoetst. Opdat een objectieve verzwarende omstandigheid kan worden aangerekend, is vereist dat de betrokkenen op de hoogte waren of moesten zijn van de verzwarende omstandigheid en dat zij de realisatie ervan gewild of minstens aanvaard hebben (te denken valt bv. aan de diefstal met geweld of bedreiging). Voor bepaalde verzwarende omstandigheden zou de toetssteen aan het voorzienbaar karakter moeten volstaan. Dit impliceert dat betrokkene bij machte was om de verzwarende omstandigheid te voorzien ook al heeft men dit in concreto niet gedaan (te denken valt aan bv. de gevolgen voor de fysieke integriteit

besluit bij het doctoraat van voornoemde auteur: Strafbare deelneming, Antwerpen, Intersentia, 2010, 960-993.

244 Zie over deze problematiek o.m. J. ROZIE, 'Het lot van de objectieve verzwarende omstandigheden: liever een latrelatie dan een gedwongen huwelijk', NC 2008, 264-27I.

245 EHRM 2 maart 2005, Göktepe/België; EHRM 27 maart 2008, Delespesse/België.

246 A. DE NAUW, 'Hoe algemeen is het bijzonder strafrecht? Over de invloed van leerstukken van het algemeen strafrecht op de misdrijven van gemeen recht', NC 20I4, 267. 
m.b.t. de geweldsmisdrijven). ${ }^{247}$ In een vorig randnummer ${ }^{248}$ werd trouwens reeds beargumenteerd dat in het raam van de equivalentieleer de schade altijd voorzienbaar is bij opzettelijke geweldpleging.

\section{De geestesgestoorde delinquent}

7I. Bepaalde categorieën van personen worden uit het gewone strafrecht gehouden, ofwel omdat ze het volle normbesef niet hebben, ofwel omdat ze het waardeoordeel over het onderscheid tussen goed en kwaad ontberen. Meer bepaald werden er door de wetgever specifieke regels en sancties (maatregelen) uitgewerkt t.a.v. de minderjarige en de geestesgestoorde delinquenten. T.a.v. de geestesgestoorde delinquent kan de grond van niet-toerekeningsvatbaarheid zich vertalen in de maatregel van de internering. De problematiek die in deze afdeling centraal staat, is dan ook de vraag of het bewijs van een causaal verband tussen de geestesstoornis en het gepleegde misdrijf een premisse is voor de internering.

\section{I Uitdrukkelijke wettelijke causaliteitsverwijzing}

72. In de inleiding werd reeds benadrukt dat het strafrecht doorspekt is van causaliteitsvraagstukken, maar dat de term 'causaliteit' als zodanig nergens in de wetteksten te bespeuren valt. Een uitzondering betreft evenwel het artikel 5 I , $2^{\circ}$ van de wet van 5 mei 2014 betreffende de internering van personen ${ }^{249}$ (ook Interneringswet genoemd) waar uitdrukkelijk wordt gerefereerd aan de woorden 'oorzakelijk verband'. Deze wet die uiterlijk in werking treedt op I januari $2016,{ }^{250}$ is op dit punt een kopie van artikel 5 S I, $2^{\circ}$ van de wet van 2 I april 2007 betreffende de internering van personen met een geestesstoornis, ${ }^{251}$ een wet die evenwel nooit in werking is getreden. ${ }^{252}$ Dit betekent dat thans de Wet Bescherming Maatschappijes3 (hierna WBM) nog steeds volledige geldingskracht heeft.

247 A. DE NAUW, 'Hoe algemeen is het bijzonder strafrecht? Over de invloed van leerstukken van het algemeen strafrecht op de misdrijven van gemeen recht', NC 20I4, 268-269; Voor een uitgebreide studie zie ook J. DE HERDT, Fysiek persoonlijk geweld. Een onderzoek naar de accuraatheid en coherentie van de strafrechtelijke kwalificaties en instrumenten aangewend als reactie op fysiek interpersoonlijk geweld, Antwerpen, Intersentia, 2014, nrs. 190-216.

248 Zie randnr. 4I.

249 BS 9 juli 2014.

250 Art. $I_{3} 6$ van de wet van 5 mei $20{ }_{4}$ betreffende de internering van personen, BS 9 juli $20{ }_{4}$.

$25 \mathrm{I}$ BS I3 juli 2007.

252 Art. I57 van de Interneringswet bepaalde dat de wet uiterlijk in werking zou treden op I januari 2009. Art. 7 van de wet van 24 juli 2008 houdende diverse bepalingen (II) heeft de inwerkingtredingsdatum verplaatst naar uiterlijk I januari 2012 (BS 7 augustus 2008). De wet van 28 december 20 Ir houdende diverse bepalingen inzake justitie (I) (BS 30 december 20II) stelde de inwerkingtredingsdatum dan weer uit tot uiterlijk I januari 20I3, maar nog voor deze datum stelde artikel 3I van de wet van 3I december 2012 houdende diverse bepalingen betreffende de justitie (BS 3 I december 20I2) de inwerkingtredingsdatum uit tot uiterlijk I januari 2015.

253 Wet van 9 april 1930 tot bescherming van de maatschappij tegen abnormalen, gewoontemisdadigers en plegers van bepaalde seksuele strafbare feiten, BS II mei I930 zoals gewijzigd bij wet r juli ig64, BS I7 juli ig64. 
73. Waar in de WBM geen enkele verplichting is opgenomen om de uitspraak van de internering te laten voorafgaan door een deskundigenonderzoek (hoewel dit in de praktijk wel gebeurt), schrijft de Interneringswet minimumcriteria voor m.b.t. het deskundigenverslag. Welnu, een van de verplichtingen houdt in dat de causaliteit voortaan uitdrukkelijk zal moeten worden omschreven: '(...) of er mogelijk een oorzakelijk verband bestaat tussen de geestesstoornis en de feiten (...)'. Het dient te worden benadrukt dat de wet gewag maakt van een 'mogelijk oorzakelijk verband', zodat het lijkt dat het causaal verband niet moet vaststaan om tot ontoerekeningsvatbaarheid te besluiten. De invoeging van het woord 'mogelijk' is het gevolg geweest van een aangenomen amendement n.a.v. een door een parlementslid geformuleerde opmerking dat het onmogelijk is voor de deskundige om met volledige zekerheid een oorzakelijk verband vast te stellen tussen de feiten en de geestesstoornis. ${ }^{254}$ De Raad van State verduidelijkte dat het niet aan de deskundige toekomt om zich uit te spreken over de vraag of de feiten vaststaan, daar het deskundigenonderzoek plaatsvindt voordat de strafrechter de feiten als bewezen heeft verklaard. ${ }^{255}$ In de memorie van toelichting wordt in dezelfde zin beargumenteerd dat de vaststelling van het oorzakelijk verband door de deskundige niet betekent dat de deskundige zich zal uitspreken over de vraag of de feiten bewezen zijn, nu deze vraag tot de exclusieve bevoegdheid van de rechter behoort. ${ }^{256}$ De strafrechter beoordeelt wel degelijk op onaantastbare wijze de bewijswaarde van het deskundigenverslag. ${ }^{257} \mathrm{Om}$ ervan af te wijken hoeft hij, behoudens als er conclusies zijn, geen uitleg te geven en moet hij de debatten niet heropenen. ${ }^{25} 8$

\subsection{De strafrechter en het causaal verband in het raam van de internering}

74. De vraag rijst in welke mate de strafrechter zich zal moeten buigen over het causaal verband tussen de geestesstoornis en het gepleegde misdrijf. Het antwoord dient te worden genuanceerd.

Taalkundig gezien wordt er op het eerste gezicht geen causaal verband vooropgesteld m.b.t. de wettelijke voorwaarden tot internering. In het artikel 9 van de nieuwe (nog niet in werking getreden) Interneringswet wordt bepaald dat internering kan worden bevolen van een persoon

254 Verslag namens de Commissie voor de Justitie bij het wetsontwerp betreffende de internering van personen die lijden aan een geestesstoornis, Parl.St. Kamer 2006-2007, nr. 284I/004, 63-64 en het hieruit voortvloeiende amendement nr. 7, Parl.St. Kamer 2006-2007, nr. 2841/002, 4.

255 Advies van de Raad van State bij het wetsontwerp betreffende de internering van personen die lijden aan een geestesstoornis, Parl.St. Kamer 2006-2007, nr. 284I/00I, I3I.

256 Memorie van toelichting bij het wetsontwerp betreffende de internering van personen die lijden aan een geestesstoornis, Parl.St. Kamer 2006-2007, nr. 284I/oor, 20-2I.

257 Zie o.m. Cass. 6 maart I967, Arr.Cass. I966-67, 852; Cass. 3I maart 1969, Arr.Cass. I969, 723; Cass. 5 januari 1982, Arr.Cass. I98I-82, 578; Cass. 8 februari I984, Arr. Cass. I983-84, 698; Cass. II maart I987, Arr.Cass. 1986-87, 912; Cass. 2 juni 1992, Arr.Cass. I99I-92, 936; Cass. 2 juni 1992, Arr.Cass. I99I-92, 936; Cass. I5 september 2010, T.Strafr. 20II, 64; Cass. I7 september 2013, NC 20I4, 55, noot S. DEWULF en J. ROZIE, 'Onvoorspelbaar recht? Over creatieve, artificiële en correcte interpretaties van de wet m.b.t. het Europees aanhoudingsbevel en de beoordeling van de geestestoestand'.

258 Cass. 22 januari 2008, NC 2008, I40. 
'a) die een als misdaad of wanbedrijf omschreven feit heeft gepleegd waarop een gevangenisstraf is gesteld en b) die op het ogenblik van de beoordeling aan een geestesstoornis lijdt die zijn oordeelsvermogen of de controle over zijn daden tenietdoet of ernstig aantast en c) ten aanzien van wie het gevaar bestaat dat hij tengevolge van zijn geestesstoornis desgevallend in samenhang met andere risicofactoren opnieuw misdrijuen zal plegen.'

Het artikel $8 \mathrm{WBM}$ dat nu nog van kracht is, omschrijft de cumulatieve interneringsvoorwaarden dan weer als volgt: 'een misdaad of wanbedrijf hebben gepleegd en zich in een van de in artikel 1 bepaalde staten bevinden' (dit is 'verkeren hetzij in staat van krankzinnigheid, hetzij in een ernstige staat van geestesstoornis of van zwakzinnigheid die hem ongeschikt maakt tot het controleren van zijn daden').

75. Het uitgangspunt voor internering is nochtans wél dat er een causaal verband aanwezig moet zijn tussen de geestesstoornis en het gepleegde misdrijf en dit zowel onder de actieradius van de huidige WBM als van de nog niet in werking getreden Interneringswet. Het is niet omdat iemand een geestesstoornis heeft dat de internering ipso facto om de hoek komt loeren. Uit de aanwezigheid van een geestesstoornis kan niet automatisch worden besloten of iemand al dan niet in staat is zijn daden te controleren. ${ }^{259}$ Een 'post hoc, ergo propter hoc'- redenering ('daarna en derhalvewaarom') is volgens de psychiatrische literatuur de meest voorkomende denkfout m.b.t. het causaliteitsvraagstuk. Dit betekent dat de vaststelling van een tijdsverband onvoldoende is als bewijs van het causaal verband. ${ }^{260}$ Ook personen gediagnosticeerd met een geestesstoornis kunnen misdrijven plegen die niet in oorzakelijk verband staan met de geestesstoornis. Zo kan een persoon met een bepaalde geestesstoornis bv. overgaan tot het plegen van een fiscaal misdrijf zonder dat zijn geestesstoornis hem hiertoe heeft aangezet ${ }^{26 \mathrm{I}}$ of zal een psychopaat met bepaalde driften meestal nog in staat zijn een kosten-batenanalyse van zijn handelen te maken. ${ }^{262}$ In voorkomend geval is er geen sprake van ontoerekeningsvatbaarheid en zal er een straf kunnen worden uitgesproken. De vraag naar toerekeningsvatbaarheid impliceert m.a.w. wel degelijk in eerste instantie een onderzoek naar het causaal verband tussen het misdrijf en de geestesstoornis. Er zal dus moeten worden nagegaan of het misdrijf onder invloed van die psychische stoornis werd begaan. ${ }^{263}$ In de strafrechtelijke literatuur wordt wel eens gewag gemaakt van een 'determinerende invloed'. ${ }^{264}$ Deze terminologie leunt nauw aan bij de causaliteitstheorie van de efficiënte oorzaak of de beslissende oorzaak. Die theorie is hier nochtans niet nodig. Conform de equivalentietheorie volstaat het voor de strafrechter na te gaan of de geestesstoornis een noodzakelijke

259 P. COSYNS en J. CASSELMAN, Gerechtelijke psychiatrie, Antwerpen, Garant, 2005, 3I; C. DILLEN, 'Het kalf is bijna verdronken! Evolutie in de forensische psychiatrie', Panopticon 200I, 533.

260 P. COSYNS en J. CASSELMAN, Gerechtelijke psychiatrie, Antwerpen, Garant, 2005, 28.

26I E. GOOSSENS, 'Psychopaten zijn toerekeningsvatbaar. Een strafrechtelijk dogma onder de loep', Jura Falc. 2010-20II, I5-I6.

262 A. JEURISSEN, 'Het morele element in hoofde van de geestesgestoorde delinquent', NC 20II, I68.

263 Zie ook H. SMETS, R. VERELST, J. VANDENBERGHE, 'Geestesziek en gevaarlijk: gedwongen opname of internering? Het Belgische wettelijke kader', Tijdschrift voor psychiatrie 2009, 2 I9.

264 F. VERBRUGGEN en R. VERSTRAETEN, Strafrecht en strafprocesrecht voor bachelors, Deel II, Antwerpen, Maklu, 2013, 377 . 
voorwaarde was voor de realisatie van het misdrijf. Er moet m.a.w. worden nagegaan of zonder de geestesstoornis het misdrijf zich ook had voorgedaan, zoals het zich in concreto heeft voorgedaan. In de psychiatrische literatuur lezen we het voorbeeld van de schizofreen die een diefstal pleegt zonder dat hij of zij acuut psychotisch is. ${ }^{265} \mathrm{De}$ schizofrene stoornis heeft ongetwijfeld een invloed op het oordeelsvermogen, maar of deze nu alleen een rol heeft gespeeld op het ogenblik van de feiten, is niet altijd te achterhalen. Vanuit psychiatrisch perspectief mag de notie 'causaal verband' dus zeker niet worden geïnterpreteerd in de zin van een absoluut, volledig of determinerend verband. In de casus van de stelende schizofreen zou men kunnen voorhouden dat er een 'causaal verband' is, wanneer de stoornis prominent aanwezig is en een permanente invloed heeft op het oordeelsvermogen van de betrokkene.

76. In de memorie van toelichting van de Interneringswet van 2I april 2007 wordt het bewijs van het gewone causaal verband, zonder bijkomende vereisten van determinerende invloed, eveneens in de verf gezet door te stellen dat 'om een persoon te kunnen interneren de rechter dus op grond van een expertise moet vaststellen of er wel een causaal verband is tussen de begane feiten en de geestesstoornis en of het gaat om een ernstige aanhoudende geestesstoornis (...)'. ${ }^{266}$ De parlementaire voorbereidingen zijn verder stilzwijgend over de criteria die een causaal verband kunnen staven. Men mag dus impliciet, maar zeker aannemen dat hier ook de equivalentietheorie moet worden toegepast. Uit de rechtspraak kan hoe dan ook impliciet de noodzaak van een causaal verband worden afgeleid. Het Hof van Cassatie aanvaardt immers in algemene bewoordingen dat een bepaald persoon voor verschillende feiten zowel het voorwerp van een internering als van een strafrechtelijke sanctie kan uitmaken. ${ }^{267}$ Een dergelijke uitspraak heeft alleen maar bestaansreden in de hypothese dat voor misdrijf A er wel een causaal verband kan worden bewezen tussen de geestesstoornis en het misdrijf maar niet voor misdrijf $\mathrm{B}$, dan wel in de hypothese dat de toepassingsvoorwaarden voor de internering t.a.v. één misdrijf niet vervuld zijn (bv. omdat het gepleegde misdrijf een overtreding is).

77. Een andere indicatie voor de aanwezigheid van een causaal verband tussen de geestesstoornis en het gepleegde misdrijf, ligt besloten in de derde cumulatieve voorwaarde tot internering. De Interneringswet bepaalt dat internering kan worden bevolen 'ten aanzien van wie het gevaar bestaat dat hij tengevolge van zijn geestesstoornis desgevallend in samenhang met andere risicofactoren opnieuw misdrijuen zal plegen'. ${ }^{268}$ In de

265 C. DILLEN, 'Het kalf is bijna verdronken! Evolutie in de forensische psychiatrie', Panopticon 200I, 533 .

266 Memorie van toelichting bij het wetsontwerp betreffende de internering van personen die lijden aan een geestesstoornis, Parl.St. Kamer 2006-2007, nr. 284I/oor, 8. In de parlementaire voorbereidingen die de Interneringswet van 5 mei 2014 zijn voorafgegaan, is men stilzwijgend over deze topic.

267 Cass. I6 februari $\mathrm{Ig}_{93}$, Arr.Cass. $\mathrm{Ig}_{93}-84,766$. Wat wel onmogelijk is, is dat voor eenzelfde feit onder verschillende wetsomschrijvingen tegelijkertijd een buitenvervolgingstelling en een internering wordt bevolen (Cass. I5 juni I993, Arr.Cass. I993, 590).

268 In de Interneringswet van 2I april 2007 wordt deze voorwaarde omschreven als 'het gevaar dat betrokkene tengevolge van zijn geestesstoornis opnieuw misdrijven zal plegen'. 
WBM wordt met geen woord gerept over deze voorwaarde. Nochtans vloeide reeds lange tijd uit vaste rechtspraak van het Hof van Cassatie ${ }^{269}$ voort dat de verdachte op het ogenblik van de berechting moet verkeren in een staat van sociale gevaarlijkheid. Het vereisen van deze bijkomende voorwaarde van 'gevaar voor herval' zorgt ervoor dat de internering moeilijk kan worden bevolen bij het ontbreken van ieder verband tussen de geestesstoornis en het misdrijf, anders bestaat er geen grond voor deze bepaling. In de memorie van toelichting wordt benadrukt dat het hervallen zowel het hervallen in de aanvankelijke toestand van geestesstoornis beoogt als in de delinquentie die in causaal verband staat met de vastgestelde geestesstoornis. ${ }^{270}$

78. Ter illustratie van de noodzaak van een causaal verband tussen geestesstoornis en het gepleegde misdrijf kan worden gewezen op een gemediatiseerde Gentse assisenzaak waarbij de beschuldigde zich moest verantwoorden voor vier moorden en 25 moordpogingen (hoewel in de motivering niet uitdrukkelijk werd gerefereerd aan de causaliteitsnotie). In deze zaak werd geoordeeld dat er sprake was van een 'ernstige persoonlijkheidsstoornis type schizotypische persoonlijkheidsstoornis met ook trekken van narcistische en antisociale persoonlijkheidsstoornis, waardoor de beschuldigde korte psychotische opstoten kan doen en depressieve episodes kan ontwikkelen'. Deze ernstige geestesstoornis en het gegeven dat de beschuldigde omwille van zijn dubbel profiel van serie- en massamoordenaar werd bestempeld als uiterst gevaarlijk voor de maatschappij, stonden er echter volgens de jury niet aan in de weg dat het oordeelsvermogen van de beschuldigde of de controle over zijn daden op het ogenblik van de feiten en op het ogenblik van de berechting niet werden tenietgedaan noch ernstig werden aangetast. In de motivering werd ook gewezen op de koelbloedige en ijzige manier waarop de feiten in het kinderdagverblijf werden gepleegd, alsook op de grondige voorbereidingshandelingen. De beschuldigde werd uiteindelijk veroordeeld tot levenslange opsluiting voor vier bewezen verklaarde moorden en vijfentwintig pogingen tot moord..$^{271}$

79. Volledigheidshalve dient te worden aangestipt dat de Nederlandse Hoge $\operatorname{Raad}^{272}$ voor de oplegging van de terbeschikkingstelling of de tbs (d.i. de Nederlandse evenknie van de internering) geen causaal verband doch enkel een gelijktijdigheidsverband vooropstelt. De vraag zal enkel moeten worden beantwoord of de geestesstoornis bestond ten tijde van het misdrijf. De opvatting dat waarschijnlijkheidsoordelen geen rol mogen spelen, vindt volgens de Hoge Raad geen steun in het recht. Het gelijktijdigheidsverband kan trouwens ook worden afgeleid uit de

269 Zie bv. Cass. 26 februari I934, Pas. I934, I, I80.

270 Memorie van toelichting bij het wetsontwerp betreffende de internering van personen die lijden aan een geestesstoornis, Parl.St. Kamer 2006-2007, nr. 284I/oor, 8.

27 I M.b.t. de schuld zie Assisen Gent 22 maart 2013 (zaak K.D.G.), arrestnr. 2013/5, niet-gepubliceerd; M.b.t. de straf zie assisen Gent 27 maart 2013 (zaak K.D.G.), arrestnr. 2013/6, niet-gepubliceerd.

272 HR 22 januari 2008, ECLI:NL:HR:2008:BCI3II (Kraggenburgzaak). Zie nochtans o.m. J. DE HULLU, Materieel strafrecht, Deventer, Kluwer, 2009, 337 e.v.; G. KNIGGE, 'Strafuitsluitingsgronden en de structuur van het strafbaar feit', in X (ed.), Vereniging voor de vergelijkende studie van het recht van België en Nederland, I993, 26; J. VAN BEMMELEN en F.C. VAN HATTUM, Hand- en leerboek van het Nederlandse strafrecht, Arnhem, Gouda Quint, I953, 334 en 340. 
wettekst (art. 37a Sr.): 'De verdachte bij wie tijdens het begaan van het feit gebrekkige ontwikkeling of ziekelijke stoornis van de geestesvermogens bestond kan op last van de rechter ter beschikking worden gesteld (...)'.

8o. Het uitgangspunt mag misschien wel zijn dat er in België een causaal verband moet worden vastgesteld tussen de geestesstoornis ('verkeren hetzij in staat van krankzinnigheid, hetzij in een ernstige staat van geestesstoornis of van zwakzinnigheid die hem ongeschikt maakt tot het controleren van zijn daden' onder de WBM; 'op het ogenblik van de beoordeling aan een geestesstoornis lijden die zijn oordeelsvermogen of de controle over zijn daden tenietdoet of ernstig aantast' onder de Interneringswet) en het gepleegde misdrijf (misdaad of wanbedrijf onder de WBM; misdaad of wanbedrijf waarop een gevangenisstraf is gesteld onder de Interneringswet), toch zal dit uitgangspunt niet in alle gevallen overeind kunnen blijven. Dit heeft te maken met het gegeven dat de interneringsvoorwaarden verenigd moeten zijn op het ogenblik van de berechting en niet op het ogenblik van het plegen van het misdrijf. Er rijst geen probleem wanneer de voorwaarden aanwezig zijn zowel op het ogenblik van het plegen van het misdrijf als op het tijdstip van de berechting. Wanneer de voorwaarden niet langer aanwezig zijn op het tijdstip van de berechting, zal de vrijspraak moeten volgen op grond van artikel 7I Sw. ('er is geen misdrijf wanneer de beschuldigde of de beklaagde op het ogenblik van het feit in staat van krankzinnigheid was'; de nieuwe nog niet in werking getreden versie ingevolge de Interneringswet van 5 mei 2014 luidt als volgt: 'er is geen misdrijf wanneer de beschuldigde of de beklaagde op het tijdstip van de feiten leed aan een geestesstoornis die zijn oordeelsvermogen of de controle over zijn daden heeft tenietgedaan of ernstig heeft aangetast'. ${ }^{273}$ Dit impliceert per definitie dat ook in het artikel 7I Sw. een causaliteitsvoorwaarde vervat zit. Het artikel 7I Sw. zal dus alleen maar kunnen worden toegepast wanneer de geestesstoornis op het ogenblik van het feit in oorzakelijk verband staat met het misdrijf.

Moeilijker wordt het wanneer de betrokkene op het tijdstip van het plegen van het misdrijf als 'normaal' kan worden bestempeld, doch niet meer op het tijdstip van de berechting. Per definitie is er dan geen link tussen de aanwezige geestesstoornis en het gepleegde misdrijf. Daar het tijdstip van berechting cruciaal is, betekent dit nochtans wel dat wanneer de betrokkene op het ogenblik van de feiten 'normaal' was, doch op het ogenblik van de berechting aan een geestesstoornis lijdt die zijn oordeelsvermogen of de controle over zijn daden tenietdoet of ernstig aantast, hij geïnterneerd kan worden indien de overige voorwaarden vervuld zijn. Aan de vraag van het causaal verband komt men in deze hypothese dan zelfs niet toe.

\subsection{Pijnpunten en remedies}

8I. De strafrechter heeft een bijna onbegrensde beoordelingsvrijheid. Toerekeningsvatbaarheid is het resultaat van een juridische afweging. Het dient te worden 
benadrukt dat de motivering van de rechterlijke uitspraak waarin de geestesstoornis al dan niet zal worden verbonden aan het concrete misdrijf cruciaal zal zijn. Wanneer de geestesstoornis zich reeds manifesteerde op het ogenblik van het plegen van het misdrijf, kan het deskundigenverslag een inspiratiebron zijn. In het artikel 9 van de nieuwe Interneringswet wordt ook voorzien in de mogelijkheid eerder uitgevoerd deskundigenonderzoek te actualiseren, zodat de rechter niet noodzakelijk een nieuw onderzoek moet bevelen vooraleer hij zijn beslissing neemt. Daarnaast zal de strafrechter zich moeten verlaten op andere criteria zoals de houding van de verdachte tijdens het onderzoek, zijn houding naar de slachtoffers, enz.

82. Het blijft een spijtige zaak dat het een 'alles of niets zaak' is. De wet kent geen regime van verminderde toerekeningsvatbaarheid: ofwel is men toerekeningsvatbaar ofwel is men het niet. De strafrechter kan dus nooit weten of hij bij een verminderde toerekeningsvatbaarheid al dan niet de juiste keuze maakt. Ook lijkt het in een aantal gevallen een bijna onmogelijke opdracht de causaliteit vast te stellen tussen de geestesstoornis en het gepleegde misdrijf. Het is nochtans mogelijk dat iemands controle of oordeelsvermogen over zijn daden niet geheel afwezig wordt geacht of ernstig is aangetast, maar wel in die mate door de geestesstoornis is aangetast dat een 'normaal functioneren' onmogelijk wordt gemaakt. Ook in de Belgische doctrine wordt gewezen op het gegeven dat men in de praktijk veelal wordt geconfronteerd met halfslachtige toestanden. ${ }^{274}$

83. Het dient te worden benadrukt dat oorzakelijke factoren in de psychiatrie vaak meervoudig zijn. ${ }^{275}$ Voor de twijfelgevallen is daarom een systeem van verminderde toerekeningsvatbaarheid op zijn plaats ${ }^{276}$ wat zou moeten kunnen leiden tot combinatie-uitspraken van straf met beveiligingsmaatregel zoals dit in Nederland ${ }^{277}$ en Duitsland gebeurt. ${ }^{278}$ Verminderd toerekenen moet evenwel worden onderscheiden van partieel toerekenen. Het laatste impliceert alleen dat een bepaalde geestesstoornis geen invloed heeft op alle handelingen van de betrokkene en er m.a.w. niet altijd een causaal verband kan worden ontwaard. ${ }^{279}$ Het invoeren van te veel

274 Zie bv. N. COLETTE-BASECQZ, 'Quel devenir pour les malades mentaux 'délinquants'?, in F. DERUYCK en M. ROZIE (eds.), Het strafrecht bedreven. Liber Amicorum Alain De Nauw, Brugge, Die Keure, 20II, I03; J. MATTHIJS, 'La loi de défense sociale à l'égard des anormaux. Evolution des concepts', JT I965, I67-I68; P. STAQUET, 'Loi relative aux droits du patient et psychiatre', in Liber Amicorum Jean-Luc Fagnart, Louvain-la-Neuve, Anthémis, 2008, 8I 2.

275 P. COSYNS en J. CASSELMAN, Gerechtelijke psychiatrie, Antwerpen, Garant, 2005, 27.

276 Zie ook G. MEYNEN, 'Een juridische standaard voor ontoerekeningsvatbaarheid?', NJB 20I3, I389-I390.

277 Voor een uitgebreide recente analyse zie het proefschrift: M.J.F. VAN DER WOLF, TBS. Veroordeeld tot vooroordeel, Oisterwijk, Wolf Legal Publishers, 20I2, 8I7p.

278 Zie voor een pleidooi voor gecombineerde uitspraken ook K. HANOULLE en F. VERBRUGGEN, 'Ivorentorenmentaliteit in de kerkers? Het problematische begrip toerekeningsvatbaarheid', in F. DERUYCK en M. ROZIE (eds.), Het strafrecht bedreven. Liber Amicorum Alain De Nauw, Brugge, Die Keure, 20II, 330-332. Voornoemde auteurs poneren hierbij ook dat de Interneringswet enerzijds het verband accentueert tussen het feit en de stoornis, maar dat dit moeilijk te rijmen valt met de onbepaalde duur van de internering. Een maximumduur van de internering op basis van de wettelijke straf zou voor hen een minimumwaarborg moeten zijn.

279 A. JEURISSEN, 'Het morele element in hoofde van de geestesgestoorde delinquent', NC 20 II, I70. 
subcategorieën lijkt dan weer te complex te zijn. In dit verband kan worden gewezen op de Nederlandse situatie waar men lijkt te willen terugkomen op het vanuit de rechtspraktijk ontstane gradueel stelsel van vijf categorieën van (on)toerekeningsvatbaarheid (toerekeningsvatbaarheid; enigszins verminderd toerekeningsvatbaar; verminderd toerekeningsvatbaar; sterk verminderd toerekeningsvatbaar; ontoerekeningsvatbaar). Zo heeft de Nederlandse Vereniging voor Psychiatrie in 2012 een Richtlijn psychiatrisch onderzoek en rapportage in strafzaken ${ }^{280}$ uitgevaardigd waarbij de vraag centraal stond hoe zo objectief mogelijk op wetenschappelijke gronden aan de strafrechter kan worden gerapporteerd. De voornoemde richtlijn benadrukt dat de term '(on)toerekeningsvatbaarheid' tot verwarring leidt, omdat het verkeerdelijk de indruk wekt dat het een meetbaar gegeven is. De gedragsdeskundigen kunnen hoogstens een advies verstrekken ten behoeve van het toerekenen waarbij inhoudelijke psychiatrische argumenten worden gegeven aan de strafrechter. Wanneer het tenlastegelegde feit niet ondubbelzinnig voortvloeit uit een geestesstoornis (maar dus ook ingegeven kan zijn door andere factoren) kan hoogstens worden vastgesteld dat er tot op zekere hoogte een causaal verband bestaat tussen de geestesstoornis en het gepleegde strafbaar feit. Er wordt benadrukt dat er nood is aan een tussencategorie en er dus van een verminderde toerekeningsvatbaarheid sprake kan zijn, maar de richtlijn voegt er onmiddellijk aan toe dat een geobjectiveerde classificatie binnen het gebied van die verminderde beïnvloeding niet mogelijk is. Aangezien forensisch psychiatrisch onderzoek geen wetenschappelijke basis biedt voor een schaalverdeling in dit verband, is er volgens de Nederlandse Vereniging voor Psychiatrie slechts ruimte voor drie hypothesen:

- $\quad$ Er is geen psychische stoornis die van invloed is geweest op het ten laste gelegde feit (advies: toerekenen).

- Er is een psychische stoornis die het ten laste gelegde feit heeft veroorzaakt (advies: niet toerekenen).

- Er is een psychische stoornis die weliswaar invloed uitoefende op het ten laste gelegde feit, maar daar niet als enige factor toe heeft geleid (advies: verminderd toerekenen).'

Voorgaande impliceert m.a.w. dat wanneer de topic van de ontoerekeningsvatbaarheid in het vizier komt, de strafrechter best uit een palet van drie keuzemogelijkheden zou moeten kiezen: (I) er is sprake van een causaal verband tussen de geestesstoornis en het gepleegde misdrijf en de geestesstoornis is nog aanwezig op het ogenblik van de uitspraak; (2) er is geen sprake van een causaal verband tussen de geestesstoornis en het gepleegde misdrijf: (3) er is sprake van een pluraliteit van oorzaken, waaronder de geestesstoornis van de dader, en de geestesstoornis is nog aanwezig op het ogenblik van de uitspraak. In de laatste hypothese is een combinatie-uitspraak van internering en straf aangewezen. Voor de uitzonderingsgevallen waar er geen causaal verband kan worden ontwaard, omdat de geestesstoornis enkel maar aanwezig is op het tijdstip van de uitspraak, blijft een interneringsuitspraak

280 Richtlijn psychiatrisch onderzoek en rapportage in strafzaken van de Nederlandse Vereniging voor Psychiatrie, 63-65 te raadplegen op www.nvvp.net/publicaties/richtlijnen. 
op zijn plaats. Dit is trouwens volledig in overeenstemming met de rechtspraak van het Europees Hof voor de Rechten van de Mens. Het Europees Hof ziet de rechtvaardiging voor de internering van een persoon met een geestesstoornis immers niet in het causaal verband tussen de stoornis en het gepleegd misdrijf, maar tussen de stoornis en de noodzaak tot vrijheidsbeneming. ${ }^{28 \mathrm{r}}$

\section{Causaliteit in het strafrecht: de sanctie}

\section{De spiegelstraf}

84. Het is maar wanneer de dader, mededader of medeplichtige een misdrijf heeft gepleegd dat wederrechtelij $\mathrm{k}^{282}$ en verwijtbaar ${ }^{283}$ is en hij hiervoor toerekeningsvatbaar $^{284}$ en strafwaardig ${ }^{285}$ wordt geacht, dat de strafrechter zich zal inlaten met de bestraffing. ${ }^{286}$ Op het eerste gezicht is het moeilijk een causaliteitsvraagstuk te ontwaren op het niveau van de sanctie. Gezien het legaal karakter van de straf zal de strafrechter immers enkel een straf mogen uitspreken waarvan de aard en de maat door de wet worden bepaald. Een causaal verband is dan ook alleen maar aanwezig bij de spiegelstraffen waarbij de wettelijk verankerde bestraffing op een of andere wijze de aard van het onderliggende misdrijf reflecteert.

In een ver strafrechtelijk verleden werd een wel erg letterlijke interpretatie gegeven aan de notie 'spiegelstraf'. Tal van voorbeelden kunnen worden geciteerd waarin bij wijze van veroordeling het misdrijf als het ware opnieuw werd gepleegd. Zo waren ooit wrede lijfstraffen n.a.v. een veroordeling tot een geweldsmisdrijf schering en inslag. In de literatuur wordt ook gewag gemaakt van een middeleeuwse praktijk van

28I EHRM 24 oktober 1976, Winterwerp/Nederland, \$ 39: 'except in emergency cases, the individual concerned should not be deprived of his liberty when he has been reliably shown to be of "unsound mind". EHRM 23 februari 1984, Luberti/Italië, § 27 en EHRM 24 oktober 1997, Johnson/Verennigd Koninkrijk, § 6o: "(...) an individual cannot be considered to be "unsound mind" and deprived of his liberty unless the following three minimum conditions are satisfied: firstly, he must reliably be shown to be of unsound mind; secondly, the mental disorder must be of a kind or degree warranting compulsory confinement; thirdly, and of sole relevance to the case at issue, the validity of continued confinement depends upon the persistence of such a disorder (...)'.

282 Bij gebreke van wederrechtelijkheid is er sprake van rechtvaardigingsgronden. Rechtvaardigingsgronden zijn door de wet of het recht erkende omstandigheden waardoor de wederrechtelijkheid van de gestelde daad opgeheven wordt en waardoor deze daad geoorloofd is of gerechtvaardigd wordt. Valt de wederrechtelijkheid weg, dan is er geen misdrijf meer.

283 Bij gebreke van verwijtbaarheid is er sprake van schuldontheffingsgronden. Schuldontheffingsgronden zijn omstandigheden door de wet of door het recht bepaald waardoor de dader van het misdrijf geen verwijt treft wegens de concrete situatie waarin hij de wettelijke delictsomschrijving stelt, al blijft die wederrechtelijk.

284 Zo kan de grond van niet-toerekeningsvatbaarheid van de geestesstoornis leiden tot de internering. Het is en blijft een misdrijf, het element van de verwijtbaarheid blijft bestaan, maar er is geen toerekeningsvatbaarheid.

285 Bij gebreke aan strafwaardigheid is er sprake van strafuitsluitende verschoningsgronden. Strafuitsluitende verschoningsgronden kunnen na de rechtvaardigingsgronden, de schuldontheffingsgronden en de gronden van niet-toerekeningsvatbaarheid de laatste contra-indicatie zijn waardoor de dader van een misdrijf aan bestraffing ontsnapt.

286 M.b.t. de bestanddelen van het misdrijf en de tegenindicaties van de bestraffing zie o.m. A. DE NAUW, Inleiding tot het algemeen strafrecht, Brugge, die Keure, 2006, 37-40. 
het levend koken van de valsemunter, omdat deze voor het misdrijf het metaal had doen koken. Een spiegelstraf was in die tijd tevens de vuurdood die aan de brandstichter werd opgelegd. ${ }^{287}$ Zelfs in het Napoleontisch Strafwetboek van $\mathrm{I}^{8} \mathrm{IO}^{288} \mathrm{kan}$ een treffend voorbeeld worden gevonden. Zo werd de oudermoordenaar niet alleen veroordeeld tot de doodstraf (onthoofding door guillotine), maar werd eveneens voorafgaand aan de executie de rechterpols van de dader afgehakt. Op die manier werd duidelijk gemaakt dat de bloedband was doorgesneden. Meer algemeen moet ook de doodstraf ${ }^{289}$ voor een levensdelict onder de noemer 'spiegelstraf' worden geplaatst.

85. Vandaag kan de notie spiegelstraf alleen nog maar worden gebezigd wanneer de aard van de uitgesproken straf in causaal verband staat met het strafbaar feit zonder dat er hieraan een talio-principe of 'oog om oog tand om tand'-principe ten grondslag ligt.

Het uitgangspunt is dat de strafrechter bij de straftoemeting over een grote appreciatiemarge beschikt en hij binnen de door de wet vooropgestelde voorwaarden in eer en geweten een aan het feit en de dader aangepaste sanctie kiest. Slechts bij wijze van uitzondering zal de uitgesproken straf vandaag als spiegelstraf kunnen worden aangemerkt. Men zou kunnen stellen dat wanneer de strafrechter bij de schuldigverklaring aan een vermogensmisdrijf voor een geldboete opteert, dit een spiegelstraf is. De keuze voor de geldboete kan evenwel ook omwille van andere redenen zijn ingegeven. De motivering van de straf en strafmaat - hoewel deze soms heel vaag blijft - zou hierin meer inzicht kunnen geven. ${ }^{290}$

Het etiket spiegelstraf geldt vandaag wel ten volle bij het verval van het recht tot sturen, daar deze sanctie - of deze nu als straf of als beveiligingsmaatregel wordt aangemerkt - enkel kan worden uitgesproken wanneer aan de veroordeling een wegverkeersmisdrijf ten grondslag ligt. ${ }^{291}$ Parlementaire initiatieven strekkende om het verval van het recht tot sturen los te koppelen van de verkeersmisdrijven, hebben nog geen weerklank gevonden. ${ }^{292}$ Een uitzondering betreft het gegeven dat de

287 J. MONBALLYU, Zes eeuwen strafrecht. De geschiedenis van het Belgische strafrecht (1400-2000), Acco, Leuven, 2006, I46. Zie ook J. MONBALLYU, 'Spiegelstraffen in het Brugse strafrecht in de eerste helft van de I6 eeuw', Handelingen van het Genootschap voor geschiedenis te Brugge, vol. I43, 2006, I64I86.

288 Meer bepaald in het art. I3.

289 Hoewel de doodstraf al geruime tijd niet meer werd tenuitvoergelegd, werd de doodstraf maar in België met de Wet van ro juli 1996 tot afschaffing van de doodstraf afgeschaft (wet tot afschaffing van de doodstraf en tot wijziging van de criminele straffen, BS I augustus ig96). De grondwettelijke bepaling m.b.t. de doodstraf werd evenwel maar afgeschaft met de wet van 2 februari 2005 tot herziening van titel II van de Grondwet om er een nieuw artikel in te voegen betreffende de afschaffing van de Grondwet, BS I7 februari 2005.

290 Zie over de motivering van de straf en strafmaat J. ROZIE en C. VANDEUREN, 'De motivering van de straf en strafmaat. Komt de huidige motiveringspraktijk tegemoet aan de door de strafwetgever vooropgestelde doelstellingen?', NC 20I2, I3I-I49.

29I Zie art. 38-49 Wegverkeerswet (wet I6 maart ig 68 betreffende de politie over het wegverkeer, BS 27 maart ig68).

292 Parl.St. Kamer 2008-2009, nr. I489/oor. 
strafrechter in het raam van het misdrijf familieverlating (art. 39rbis Sw.) bij wijze van facultatieve bijkomende straf het verval van het recht tot sturen kan uitspreken. ${ }^{293}$

Een spiegelsanctie kan ook worden gezien in de sanctie van de bijzondere verbeurdverklaring of confiscatie. De verbeurdverklaring is immers een rechterlijke beslissing die het eigendomsrecht over zaken die te maken hebben met het plegen van het misdrijf aan de veroordeelde ontneemt en toekent aan de Staat, de burgerlijke partij of de belanghebbende derde. De verbondenheid of m.a.w. het causaal verband tussen het te verbeurdverklaren goed en het misdrijf lijkt dus cruciaal te zijn. De sanctie van de bijzondere verbeurdverklaring zal dan ook centraal staan in deze bijdrage.

\section{De verbeurdverklaring: algemeen kader}

86. Volgens het Strafwetboek wordt de bijzondere verbeurdverklaring toegepast op de zaken die het voorwerp van het misdrijf uitmaken, en op die welke gediend hebben of bestemd waren tot het plegen van het misdrijf, wanneer zij eigendom van de veroordeelde zijn (art. 42 lid I Sw.); op de zaken die uit het misdrijf voortkomen (art. 42 lid 2 Sw.) en op de vermogensvoordelen die rechtstreeks uit het misdrijf zijn verkregen, op de goederen en waarden die in de plaats ervan zijn gesteld en op de inkomsten uit de belegde voordelen (art. 42 lid 3 Sw.). Niets belet dat bijzondere strafwetten een afwijkende reglementering kennen inzake verbeurdverklaring. Deze specifieke bepalingen krijgen ingevolge artikel roo Sw. ${ }^{294}$ een volledige geldingskracht, zelfs indien de bijzondere wet zonder voorbehoud verwijst naar de bepalingen van Boek I van het Strafwetboek.

Volledigheidshalve moet ook melding worden gemaakt van de verbeurdverklaring als beveiligingsmaatregel. Wegens de gevaarlijke, de schadelijke of de verboden aard van zekere voorwerpen en de noodzakelijkheid deze aan de omloop te onttrekken, kan de verbeurdverklaring de gedaante krijgen van een beveiligings- of politiemaatregel. Voorbeelden zijn de verbeurdverklaring van verboden wapens, ${ }^{295}$ de verbeurdverklaring van eetwaren of dranken welke stoffen bevatten die de dood kunnen veroorzaken of de gezondheid zwaar kunnen schaden, ${ }^{296}$ de verbeurdverklaring van verdovende middelen ${ }^{297}$ en de verplichte verbeurdverklaring van onrechtmatig ver-

293 Art. I2 van de wet van I2 mei 2014 houdende wijziging van de wet van 2I februari 2003 tot oprichting van een Dienst voor alimentatievorderingen bij de FOD Financiën en tot wijziging van het Gerechtelijk Wetboek, met het oog op een effectieve invordering van onderhoudsgelden, BS 30 mei 2014.

294 Art. Ioo Sw. bepaalt: 'Bij gebreke van andersluidende bepalingen in bijzondere wetten en verordeningen, worden de bepalingen van het eerste boek van dit wetboek toegepast op de misdrijuen die bij die wetten en verordeningen strafbaar zijn gesteld, met uitzondering van hoofdstuk VII en van artikel 85.'

295 Art. 24 van de Wet van 8 juni 2006 houdende regeling van economische en individuele activiteiten met wapens, BS 9 juni 2006.

296 Art. 457 Sw.

297 Art. 4 S 6 van de Wet van 24 februari I92I betreffende het verhandelen van de giftstoffen, slaapmiddelen en verdovende middelen, ontsmettingsstoffen en antiseptica (BS 6 maart I92I) bepaalt enkel 'Onverminderd de toepassing van de artikelen 42 en 43 van het Strafwetboek, kan de rechter de ver- 
deelde toegangsbewijzen zelfs indien deze geen eigendom zijn van de veroordeelde. ${ }^{298}$

De verbeurdverklaring kan tenslotte een gemengd karakter vertonen wanneer zij tegelijkertijd een straf is en bovendien strekt tot het civielrechtelijke herstel van de schade die een derde, hetzij de Staat, hetzij een particulier heeft ondergaan. ${ }^{299}$ In dit verband kunnen worden geciteerd de verbeurdverklaring van de opbrengst van inbreuken op de auteursrechten, ${ }^{300}$ de verbeurdverklaring inzake namaak en piraterij van intellectuele eigendomsrechten ${ }^{301}$ en de verbeurdverklaring inzake douane en accijnzen ${ }^{302}$ (sommigen zien in deze vorm van verbeurdverklaring terecht eerder een straf met zakelijk karakter). ${ }^{303}$

De verbeurdverklaring is gericht tegen de delinquent die in voorkomend geval afstand zal moeten doen van het eigendomsrecht of het bezit op de n.a.v. het gepleegde misdrijf besmette goederen. De aard en mate van besmetting (of m.a.w. de vraag naar causaliteit) is determinerend om te kunnen achterhalen of het betrokken goed al dan niet vatbaar is voor verbeurdverklaring. Het uitgangspunt is dat de verbeurdverklaring wordt gekenmerkt door een ruime causaliteitsbenadering. Nochtans zullen bepaalde regels een verbeurdverklaring kunnen hypothekeren zelfs wanneer er een causaal verband aanwezig is.

\section{Uitgangspunt verbeurdverklaring: ruime causaliteitsbenadering}

87. Het wettelijk scala aan te verbeurdverklaren goederen toont aan dat de wetgever het uitgangspunt is genegen dat criminaliteit niet zou mogen lonen. Van zodra een goed door de strafwetgever als besmet goed wordt aangemerkt, komt de verbeurdverklaring om de hoek loeren.

beurdverklaring bevelen van voertuigen, toestellen en instrumenten of zaken die hebben gediend of bestemd waren om de in de artikelen $\left(2,2^{\circ}\right) 2$ bis en 3 omschreven misdrijuen te plegen of die er het voorwerp van uitmaken, zelfs indien ze niet het eigendom zijn van de veroordeelde', maar uit art. I van diezelfde wet volgt dat de regering de taak heeft om op te treden in het kader van de openbare veiligheid, waardoor de verbeurdverklaring van verdovende middelen ontegensprekelijk als beveiligings- of politiemaatregel kan worden bestempeld.

298 Zie art. 40 van de Wet van 2I december 1998 betreffende de veiligheid bij voetbalwedstrijden, $\mathrm{BS}_{3}$ februari 1999. De ratio legis van deze verbeurdverklaring is het zwartemarktcircuit terug te dringen. Volgens de memorie van toelichting zou het onlogisch zijn de toegangsbewijzen terug te geven, daar dit het risico zou inhouden dat ze opnieuw in omloop gebracht worden. Teneinde het winstoogmerk te sanctioneren, is het nodig dat de toegangsbewijzen systematisch worden verbeurdverklaard (memorie van toelichting bij het wetsontwerp betreffende de veiligheid bij voetbalwedstrijden, Parl.St. Kamer I997-I998, nr. I572/I, 26).

299 A. DE GEEST, Verbeurdverklaring, in APR, Brussel, Larcier, I97I, 59.

300 Art. 82 van de Wet van 30 juni 1994 betreffende het auteursrecht en de naburige rechten, BS 27 juli 1994, err., BS 5 november 1994, err., BS 22 november 1994, err., BS 8 augustus 1995.

30 I Art. I3 S I van de wet van I5 mei 2007 betreffende de bestraffing van namaak en piraterij van intellectuele eigendomsrechten, BS I8 juli 2007.

302 Art. 22I e.v. van het KB van I8 juli 1977 tot coördinatie van de algemene bepalingen inzake douane en accijnzen, BS 29 september 1977.

303 P. WAETERINCKX, 'Twee recente ontwikkelingen van belang voor het ondernemingsstrafrecht', in Strafrecht in breed spectrum, Brugge, die Keure, 20I4, nr. I7, ter perse. 


\section{I De bijzondere verbeurdverklaring van het voorwerp van het misdrijf, van de zaken die uit het misdrijf voortkomen en van de instrumenten van het misdrijf}

88. Een restrictievere invulling is aanwezig bij de verbeurdverklaring van het voorwerp van het misdrijf (art. 42 lid I Sw.) en van de zaken die uit het misdrijf voortkomen (art. 42 lid 2 Sw.). Onder 'zaken die het voorwerp van het misdrijf uitmaken' wordt het 'corpus delicti' begrepen. Dit is het voorwerp waarop het misdrijf materieel gezien werd gepleegd zoals de gestolen en geheelde zaken, vervalste akten, ${ }^{304}$ met bedrog verkochte koopwaar, het geld dat door de oplichting werd verkregen en witgewassen vermogensvoordelen. ${ }^{305}$ De omstandigheid dat bepaalde goederen evenwel slechts 'verband houden' met een misdrijf impliceert niet noodzakelijk dat er een causaal verband aanwezig is en dat deze goederen dus als het 'voorwerp' van dat misdrijf moeten worden beschouwd. ${ }^{306}$ 'De zaken die uit het misdrijf voortkomen' (art.42 lid 2 Sw.), zijn de producten van het misdrijf. ${ }^{307}$ Het zijn zaken die worden voortgebracht door het misdrijf, zoals de nagemaakte bankbiljetten, de vervalste eetwaren, enz. Zaken die de dader zich echter wederrechtelijk heeft toegeëigend door middel van het misdrijf en datgene dat in de plaats is getreden van het door het misdrijf verkregen goed, vallen in principe wel buiten schot..$^{308}$

89. Een ruime actieradius wordt dan weer toebedeeld aan 'de zaken die gediend hebben of bestemd waren tot het plegen van het misdrijf' (art. 42 lid I Sw.) of m.a.w. de instrumenten van het misdrijf. Niettemin kunnen alleen misdaden en wanbedrijven worden geviseerd (dit is ook het geval bij de verbeurdverklaring van het voorwerp van het misdrijf (art. 42 lid I Sw.) en van de zaken die uit het misdrijf voortkomen (art. 42 lid 2 Sw.)). De instrumenten moeten evenwel niet noodzakelijk werkelijk gediend hebben om de misdaad of het wanbedrijf te plegen. Het volstaat dat de dader ze had meegebracht om het misdrijf te plegen en het is onverschillig of hij deze instrumenten nodig heeft gehad of de gelegenheid heeft gehad ze te gebruiken. Deze voorwerpen moeten van hun normale bestemming worden afgewend, zoals het moordwapen, de valse sleutel, het voertuig waarmee iemand wordt ontvoerd, enz. Onder de formulering 'het plegen van het misdrijf' moeten niet alleen de

304 Er moet nog rekening gehouden worden met artikel 46, lid I Sv. dat een voorzorgsmaatregel van burgerlijke aard oplegt. Voornoemd artikel bepaalt: 'Wanneer authentieke akten geheel of ten dele vals verklaard zijn, beveelt het hof of de rechtbank die van de valsheid heeft kennisgenomen, dat zij zullen worden hersteld, doorgehaald of verbeterd; van alles wordt een proces-verbaal opgemaakt.' Bovendien kan een vals stuk naast het voorwerp van het misdrijf tevens het voorwerp zijn dat uit het misdrijf voortkomt. Zie P. SERVAIS, 'Sur la confiscation des écrits reconnus faux', Rev.dr.pén. I9Io, Io65; Cass. Io oktober 1966, Pas. 1967, I, I87; Arr. Cass. 1966-67, I83; Cass. I8 december 1967, Pas. I968, I, 532; Arr.Cass. I968, 569; Cass. 8 april I974, Pas. I97I, I, 821; Arr. Cass. I974, 870.

305 Art. 505 Sw. schrijft evenwel geen eigendomsvoorwaarde voor.

306 Cass. II april 2000, T. Strafr. 200I, 20, noot G. STESSENS: zo maken de vernielde, weggemaakte of verborgen goederen of voorwerpen niet het voorwerp uit van het misdrijf zoals bedoeld in art. 49 obis Sw.

307 A. DE GEEST, Verbeurdverklaring, in APR, Brussel, Larcier, I97I, 37.

308 J. SIMON, Handboek van het Belgisch strafrecht, Brussel, Bruylant, I948, I9I; Pandectes belges, $v^{\circ}$ Confiscation, nr. Io6. 
uitvoeringshandelingen van het misdrijf, maar ook de daden worden begrepen die tot voorbereiding of voltooiing van het misdrijf strekken. De notie 'bestemd om het misdrijfte plegen' moet immers worden uitgelegd als 'bestemd om het misdrijf dienstig te zijn'. Een bepaalde strekking is nochtans voorstander van een restrictieve interpretatie, waarbij enkel de concrete uitvoeringsdaden geviseerd worden. Volgens deze opvatting kunnen de zaken die tot het verrichten van voorbereidende handelingen hebben gediend of bestemd waren, en die welke gediend hebben na de voltooiing van het misdrijf niet verbeurdverklaard worden. ${ }^{309}$ Deze strekking strookt evenwel niet met de heersende rechtspraak en rechtsleer, zeker nu aan de notie 'voltooiing van het misdrijf' een veelomvattende invulling wordt gegeven. In dit verband kan worden gewezen op een recent cassatiearrest van II februari $2014^{3{ }^{10}}$ waaruit volgt dat tot de in artikel 42 lid I Sw. bedoelde zaken onder meer de zaken behoren die gediend hebben of bestemd waren voor de voorbereiding of de voltooiing van het misdrijf. Onder die zaken is ook het voertuig begrepen dat de dader van de diefstal gebruikt om de goederen die hij zich reeds heeft toegeëigend, te vervoeren uit de plaats waar zij zijn ontvreemd. Dat vervoer behoort immers tot de voltooiing van dat misdrijf. Wanneer de toepassingsvoorwaarden vervuld zijn, spreekt de strafrechter de verbeurdverklaring uit ongeacht de waarde van het betrokken goed. ${ }^{\text {II }}$ Er zijn niettemin dissonante geluiden terug te vinden: zo houdt een van de geestelijke vaders van het Strafwetboek ${ }^{312}$ voor dat er geen reden is om over te gaan tot verbeurdverklaring wanneer het betrokken goed een uiterst geringe waarde heeft (zoals de veer die werd gehanteerd om een valsheid in geschriften te plegen).

\subsection{De voordeelsontneming}

90. Causaliteitsverbanden zijn in de meest rekbare vorm aanwezig bij de bijzondere verbeurdverklaring van artikel 42 lid 3 Sw., ook de zogenoemde voordeelsontneming genoemd. Het voordeelsbegrip of 'lucra sceleris' strekt zich immers uit over drie niveaus, ook wel de primaire vermogensvoordelen, de vervangingsgoederen en de inkomsten uit de belegde voordelen genoemd ('vermogensvoordelen die rechtstreeks uit het misdrijf zijn verkregen, de goederen en waarden die in de plaats ervan zijn gesteld en de inkomsten uit de belegde voordelen'). ${ }^{313}$

9I. Met primaire vermogensvoordelen worden de vermogensvoordelen bedoeld die de dader rechtstreeks uit het misdrijf bij het plegen ervan heeft verkregen, en die zich nog in natura in zijn vermogen bevinden, bv. de gestolen goederen, het bedrag van de levensverzekering dat de dader van een doodslag door die misdaad

309 J. SIMON, Handboek van het Belgisch strafrecht, I9I; Pandectes belges, v Confiscation, nrs. 48 en 5I, 9I4915 .

3Io Cass. II februari 20I4, NC 20I4, 218.

3II Cass. 21 oktober 1836 , Pas. I836, 332.

3 I2 J. NYPELS, Le code pénal interprété, I, Brussel, Bruylant, I867, 74.

3I3 Zie hierover uitgebreid J. ROZIE, Voordeelsontneming. De wisselwerking tussen de toepassingsvoorwaarden en het rechtskarakter van de verbeurdverklaring van illegale vermogensvoordelen, Antwerpen, Intersentia, 2005, 195-26r. 
heeft opgestreken, het fiscaal voordeel dat men genereert door de niet-aangifte van bepaalde inkomsten, enz. Artikel 42 lid 3 Sw. bepaalt uitdrukkelijk dat de vermogensvoordelen rechtstreeks uit het misdrijf moeten zijn verkregen. Dit impliceert m.a.w. de vereiste van een causaal verband tussen het tenlastegelegde misdrijf en het genoten voordeel. ${ }^{314}$ Alle misdrijven (misdaden, wanbedrijven, overtredingen; opzettelijke en onopzettelijke misdrijven, enz.) komen hiervoor in aanmerking zonder onderscheid. Telkenmale zal wel een causaal verband moeten kunnen worden bewezen; niet alle misdrijven genereren dus ipso facto vermogensvoordelen..$^{35}$ Zodra een misdrijf een onrechtmatig voordeel genereert - van welke aard ook - kan het betrokken goed worden verbeurdverklaard. De vermogensvoordelen die een mededader of medeplichtige uit zijn deelneming aan het misdrijf heeft verkregen zijn uiteraard ook vermogensvoordelen die uit het misdrijf zijn verkregen. ${ }^{316}$ De twijfel die er ooit heerste m.b.t. de vraag of kostenbesparingen als vermogensvoordeel kunnen worden aangemerkt, lijkt definitief beslecht te zijn door de rechtspraak..$^{37}$ Het louter opbouwen van een fictieve schuld ${ }^{318}$ of een schuld die onbetaald is gebleven met het oogmerk om het faillissement van een vennootschap uit te stellen is evenwel geen vermogensvoordeel..$^{\text {39 }}$

92. Aangezien oorspronkelijke goederen en waarden vaak worden omgeruild, omgevormd en verdeeld teneinde ieder spoor ervan te doen verdwijnen, heeft de wetgever geoordeeld dat ook de vervangingsgoederen kunnen worden verbeurdverklaard, bv. goederen die met het gestolen geld werden aangekocht of nog het geld dat door de verkoop van de gestolen goederen werd verkregen. Wel dient steeds het laatste gesubstitueerde goed of waarde in aanmerking te worden genomen..$^{320}$ Stel dat A met drugsgeld een riante villa koopt die hij even later aan B - die volkomen te goeder trouw is - doorverkoopt, dan zal het vervangingsgoed niet langer het onroerend goed zijn, doch wel de verkoopprijs die A ervoor heeft ontvangen. Dit uitgangspunt

3 I4 G. STESSENS, 'De verbeurdverklaring', in XXXIIste Postuniversitaire cyclus W. Delva Straf- en strafprocesrecht 2005-2006, Mechelen, Kluwer, 2006, 349-350; P. WAETERINCKX, 'Het onroerend goed als vermogensvoordeel', in J. ROZIE (ed.), Het onroerend goed in het straf(proces)recht, Antwerpen, Intersentia, 20I2, 65-66.

3 I5 P. WAETERINCKX, 'Leveren alle misdrijven vermogensvoordelen op in de zin van artikel $42,3^{\circ}$ Sw?', RABG 2012, 800-809.

3 I6 Cass. 2 oktober 2007, Pas. 2007, I679.

317 Cass. 22 oktober 2003, A.R. P.03.0084.F (FJF 2004, afl.I, 25; JLMB 2004, 336, noot F. ROGGEN; JT 2004, 362, noot E. BOIGELOT; Journ.proc. 2003, afl.47I, I8, noot Ph. T.; RCJB, noot M.-A. BEERNAERT; RGCF 2005, IOI, noot H. LOUVEAUX; RW 2004-2005, 4I6, noot A. DE NAUW; Rev.dr.pén. 2004, 277; T.Strafr. I67, noot G. STESSENS; TBH 2004, I99, noot O. CREPLET; TFR 2004, I39, noot J. SPEECKE; Fiscoloog 2003, nr. 9II, I, noot G. STESSENS; De Juristenkrant 2003, nr. 78, 5, noot P. WAETERINCKX en S. DE MEULENAER); Cass. 30 januari 2007, NC 2006, 64, noot J. ROZIE, 'Over voordeelsontneming in fiscalibus'.

3I8 Cass. io januari 20I2, A.R. P.II.0938.N.; RABG 20I2, 896.

3I9 Cass. 6 februari 20I3, A.R. P.I2.II29.F.

320 J. ROZIE, Voordeelsontneming. De wisselwerking tussen de toepassingsvoorwaarden en het rechtskarakter van de verbeurdverklaring van illegale vermogensvoordelen, Antwerpen, Intersentia, 2005, 202; P. WAETERINCKX, 'Het beslag in (fiscale) strafzaken', in M. MAUS en M. ROZIE (eds.), Actuele problemen van het fiscaal strafrecht, Antwerpen, Intersentia, 20II, 574; P. WAETERINCKX, 'Het onroerend goed als vermogensvoordeel', in J. ROZIE (ed.), Het onroerend goed in het straf(proces)recht, Antwerpen, Intersentia, 20I2, 65-66. 
maakt dat de causaliteitsketen oneindig lang kan worden. Als het ware moet men de ketting volgen tot de laatst vindbare schakel. Niettemin moet er een duidelijk identificeerbare band aanwezig zijn tussen het vervangingsgoed en het illegaal vermogensvoordeel..$^{321}$ De enige voorwaarde om als vervangingsgoed te kunnen worden aangemerkt is dat het goed op legale wijze in de handel verkrijgbaar moet zijn. Werd bijvoorbeeld met het gestolen geld een verboden wapen of drugs aangeschaft, dan zal de verbeurdverklaring verplicht moeten worden uitgesproken niet als straf maar als beveiligingsmaatregel..$^{322}$

93. Onder de 'inkomsten uit de belegde voordelen' moeten de bankrenten, dividenden en opbrengsten van allerlei aard die voortvloeien uit de primaire vermogensvoordelen of de vervangingsgoederen worden begrepen. De doctrine kan worden bijgevallen waar ze poneert dat de bewijslast m.b.t. dergelijke inkomsten problematischer wordt naargelang de band met het primaire vermogensvoordeel zwakker wordt. ${ }^{323}$

94. Het dient nochtans te worden benadrukt dat het Hof van Cassatie het causaal verband tussen het bewezen verklaarde misdrijf en het waardeerbaar voordeel ruim interpreteert. ${ }^{22}$ Het Hof $^{325}$ verduidelijkt immers dat een vermogensvoordeel rechtstreeks uit het misdrijf is verkregen indien er een causaal verband bestaat tussen dit misdrijf en het vermogensvoordeel. Het begrip 'rechtstreeks' wijst niet op een beperking van de verbeurdverklaring tot de voordelen die zonder enige tussenschakel zijn verkregen uit het misdrijf. Een eventueel rechtstreeks causaal verband tussen het vermogensvoordeel met een latere verrichting doet het causaal verband tussen dit vermogensvoordeel en het voordien gepleegde misdrijf niet verdwijnen. Deze invulling van het voordeelsbegrip congrueert ontegensprekelijk met de equivalentietheorie. Het causaal verband bij de voordeelsontneming ex artikel 42 lid 3 Sw. mag immers middellijk zijn als ze maar noodzakelijk is. De vraag rijst dan ook of de term 'rechtstreeks' uit artikel 42 lid 3 Sw. nog bestaansreden heeft. De ruime causaliteitsbenadering bij de voordeelsontneming impliceert immers - net zoals bij de equivalentietheorie - dat ver verwijderde (dus zowel rechtstreekse als onrechtstreekse) oorzaken in aanmerking komen. Elke schakel van de causaliteitsketting komt dus in het vizier.

32I P. WAETERINCKX, 'Het beslag in (fiscale) strafzaken', in M. MAUS en M. ROZIE (eds.), Actuele problemen van het fiscaal strafrecht, Antwerpen, Intersentia, 20II, 573; P. WAETERINCKX, 'Het onroerend goed als vermogensvoordeel', in J. ROZIE (ed.), Het onroerend goed in het straf(proces) recht, Antwerpen, Intersentia, 2012, 66.

322 J. ROZIE, Voordeelsontneming. De wisselwerking tussen de toepassingsvoorwaarden en het rechtskarakter van de verbeurdverklaring van illegale vermogensvoordelen, Antwerpen, Intersentia, 2005, 203.

323 M. DE SWAEF, 'De bijzondere verbeurdverklaring van de vermogensvoordelen uit misdrijven', RW I990-9I, 492; A. VANDEPLAS, 'De bijzondere verbeurdverklaring van vermogensvoordelen', in Liber Amicorum M. Chatel, Antwerpen, Kluwer, I99I, 393.

324 A. DE NAUW, 'Hoe algemeen is het bijzonder strafrecht? Over de invloed van leerstukken van het algemeen strafrecht op de misdrijven van gemeen recht?', NC 20I4, nr.33, 269.

325 Cass. I8 oktober 20II, A.R. P.II.020I.N; T.Strafr. 20II, 44I, noot B. MEGANCK; Cass. Io januari 2012, A.R. P.II.0938.N. 
De strafrechter oordeelt op onaantastbare wijze of een vermogensvoordeel al dan niet uit een misdrijf is verkregen. ${ }^{26}$ De notie 'voordeel' krijgt etymologisch gezien onvermijdelijk een positieve weerklank en duidt op iets 'gunstigs' of 'nuttigs' al dan niet in vergelijking met iets anders. Het Hof van Cassatie ${ }^{327}$ vereist evenwel niet dat de vermogensvoordelen in het vermogen van de veroordeelde zijn getreden noch dat hij zich heeft verrijkt. Een vermogensvoordeel is volgens het Hof dus niet noodzakelijk een verrijking; de verbeurdverklaring kan worden uitgesproken ongeacht het voordeel dat men uit het misdrijf heeft gehaald of de bestemming die men later aan de vermogensvoordelen heeft gegeven. Het volstaat dat het vermogensvoordeel 'waardeerbaar' is. ${ }^{328}$ Het Hof van Cassatie omschreef eerder al de notie vermogensvoordeel als 'zowel goederen als waarden als elk economisch voordeel'. ${ }^{29}$ De toevoeging door het Hof van Cassatie in zijn recente rechtspraak ${ }^{33^{\circ}}$ van niet vereiste van verrijking is nochtans verwarrend, temeer daar in vroegere rechtspraak ${ }^{33 \mathrm{I}}$ werd geponeerd dat artikel 42 lid 3 Sw. op elke winst doelt die door het plegen van het misdrijf wordt verkregen. Wanneer in het burgerlijk recht gewag wordt gemaakt van een verrijking zonder oorzaak, wordt onder de term verrijking het verkrijgen van een (zakelijke of zedelijke) waarde, of de bevrijding van een last, voor zover ze beide schatbaar zijn, begrepen. ${ }^{332}$ De term 'verrijking' congrueert hier dus wel degelijk met de term 'waardeerbaar'.

95. Het uitgangspunt dat vermogensvoordelen waardeerbaar moeten zijn, speelt ten volle bij de verbeurdverklaring bij equivalent of de waardeconfiscatie van artikel 43 bis lid 2 Sw. Indien de zaken niet kunnen worden gevonden in het vermogen van de veroordeelde, raamt de rechter de geldwaarde ervan en heeft de verbeurdverklaring betrekking op een daarmee overeenstemmend bedrag. Er bestaat geen optierecht: het is enkel wanneer de vermogensvoordelen in de letterlijke zin van het woord opgesoupeerd werden dat een waardeconfiscatie mogelijk is. Artikel 43 bis lid 2 Sw. viseert dus enkel de situatie van de beklaagde die het gerealiseerde voordeel heeft opgemaakt en niet van de beklaagde die zijn buit heeft ondergebracht in andermans vermogen noch die van de situatie van de niet-individualiseerbaarheid van de vermogensvoordelen. Uit de literatuur vloeit voort dat er bij een waardeconfiscatie sprake is van vermogensvoordelen zonder relatie tot de strafvordering. Het

326 Zie o.m. Cass. I3 april I999, Arr.Cass. I999, 204; Cass. 27 september 2006, A.R. P. o6.0739.F, NC 2008, 58, noot J. ROZIE; Cass. I2 november 2013, A.R. P.I2.I744.N.

327 Cass. I2 november 20I3, A.R. P.I2.I744.N.; Zie ook Cass. 9 mei 2007, Arr.Cass. 2007, 990; Rev. dr.pén. 2007, 953; T.Strafr. 2007, 385.

328 P. WAETERINCKX, 'Het beslag in (fiscale) strafzaken', in M. MAUS en M. ROZIE (eds.), Actuele problemen van het fiscaal strafrecht, Antwerpen, Intersentia, 20II, 572; P. WAETERINCKX, 'Het onroerend goed als vermogensvoordeel', in J. ROZIE (ed.), Het onroerend goed in het straf(proces) recht, Antwerpen, Intersentia, 2012, 65.

329 Cass. 8 november 2005, NC 2006, I26. Dit vloeide reeds voort uit de conclusie van advocaatgeneraal Spreutels bij het cassatie-arrest van 22 oktober 2003 (A.R. P.03.0084.F.) waarin werd gepreciseerd dat de notie vermogensvoordeel in de zin van artikel 42 lid 3 Sw. moet worden gelezen als 'elk economisch voordeel dat uit enig misdrijf kan worden verkregen'.

330 Cass. I2 november 20I3, A.R. P.I2.I744.N.

33 Cass. I4 mei 2008, Rev.dr.pén. 2008, 1094.

332 R. DEKKERS en A. VERBEKE, Handboek burgerlijk recht, III, Antwerpen, Intersentia, 2007, 203. 
betreft legale equivalenten van een illegaal vermogensvoordeel, maar ze zijn geen surrogaat van het illegale vermogensvoordeel. ${ }^{333}$ Het zou ons echter te ver leiden te stellen dat de conditio sine qua non-toets helemaal verdwijnt bij de waardeconfiscatie. Er moet immers nog altijd worden vastgesteld dat het bewezen verklaarde misdrijf ooit een vermogensvoordeel heeft gegenereerd.

De waardering van de vermogensvoordelen komt - na voorzet van het Openbaar Ministerie met de schriftelijke ontnemingsvordering - volledig toe aan de strafrechter. De wetgever geeft echter bijna geen aanknopingspunten en plaatst alle begrotingsmogelijkheden (netto, bruto of ex aequo et bono ontnemen) op voet van gelijkheid waardoor willekeur soms troef wordt. ${ }^{334}$ Het Hof van Cassatie heeft inderdaad aanvaard dat de raming van het equivalente bedrag bij ontstentenis van nauwkeurige beoordelingsgegevens ex aequo et bono mag geschieden ${ }^{335}$ en meer algemeen is de rechter bij de raming van de vermogensvoordelen niet verplicht het nettobedrag ervan vast te leggen..$^{3{ }^{6}} \mathrm{Er}$ is geen verbod op brutoafroming, maar evenmin op nettoafroming. ${ }^{337}$ Aanvaardt men dat de voordeelsontneming er enkel toe strekt de toestand te herstellen zoals die bestond vooraleer het misdrijf werd gepleegd dan dient men de nettobegroting te onderschrijven. Kosten die dan voor aftrek in aanmerking komen, zijn de kosten die in causaal verband staan tot de voltooiing van het misdrijf. Kosten die naderhand tot stand zijn gekomen of er maar zijdelings verband mee houden kunnen niet in mindering worden gebracht. Zo dient de strafrechter bij de begroting van de vermogensvoordelen geen aftrek te doen van de schadevergoeding waartoe de beklaagde wordt veroordeeld..$^{33^{8}}$

96. De situatie is ingewikkelder in het raam van de verbeurdverklaring van vermogensvoordelen, ex artikel 43quater Sw. ook de verruimde verbeurdverklaring genoemd. ${ }^{339}$ De supplementaire vermogensvoordelen die hier kunnen worden verbeurdverklaard, zijn de zogenoemde verdere vermogensvoordelen die voortspruiten uit het misdrijf waarvoor de beklaagde werd veroordeeld of die voortspruiten uit

333 P. WAETERINCKX, 'Het beslag in (fiscale) strafzaken', in M. MAUS en M. ROZIE (eds.), Actuele problemen van het fiscaal strafrecht, Antwerpen, Intersentia, 20II, 573; P. WAETERINCKX, 'Het onroerend goed als vermogensvoordeel', in J. ROZIE (ed.), Het onroerend goed in het straf(proces) recht, Antwerpen, Intersentia, 2012, 67.

334 Cass. 27 september 2006, NC 2008, 58, noot J. ROZIE, 'Een netto-, een bruto- of een ex aequo et bono-begroting van vermogensvoordelen: voor elk wat wils'.

335 Cass. I4 december 1994, Arr.Cass. 1994, IIo8.

336 Cass. 27 september 2006, NC 2008, noot J. ROZIE; T.Strafr. 2007, 4I, noot J. VAN GAEVER, 'De omvang van het begrip vermogensvoordeel'.

337 D. VANDERMEERSCH, 'La peine pécuniaire déterminée en fonction du profit escompté de l'infraction: une peine percutante en réponse à la délinquance fondée sur le profit', in F. DERUYCK en M. ROZIE (eds.), Het strafrecht bedreven. Liber Amicorum Alain De Nauw, Brugge, Die Keure, 20I3, 865.

338 Cass. 2I april 2009, A.R. P.o8.1748.N; Cass. I2 juni 20I2, NC 20I2, 3I8. Meer algemeen m.b.t. de problematiek van niet-aftrek van de kosten die verbonden zijn aan de realisatie van het misdrijf zie Cass. 29 mei 200I, T.Strafr. 2002, 37-39.

339 Dit artikel werd ingevoerd door de wet van ig december 2002 tot uitbreiding van de mogelijkheden tot inbeslagneming en verbeurdverklaring in strafzaken, BS I4 februari 2013. Zie hierover uitgebreid J. ROZIE, Voordeelsontneming. De wisselwerking tussen de toepassingsvoorwaarden en het rechtskarakter van de verbeurdverklaring van illegale vermogensvoordelen, Antwerpen, Intersentia, 2005, 347-375. 
identieke feiten en die verworven zijn over een relevante periode. Onder bepaalde voorwaarden heeft de wetgever er dus voor geopteerd de vereiste graad van causaliteit tussen het misdrijf en de eruit voortvloeiende vermogensvoordelen af te zwakken. Dit heeft tot gevolg dat voor de gevallen omschreven in artikel 43quater Sw. niet alleen die zaken kunnen worden verbeurdverklaard waarvan de vervolgende partij aannemelijk heeft gemaakt dat ze afkomstig zijn van het misdrijf waarvan de veroordeelde effectief schuldig werd bevonden, doch ook die zaken waarvan aannemelijk werd gemaakt dat ze voortkomen uit identieke feiten ${ }^{340}$ en waaraan de verdediging de rechtmatige oorsprong niet geloofwaardig heeft kunnen maken. Het aantonen van een causaal verband tussen het bewezen verklaarde misdrijf en de vermogensvoordelen wordt hiermee op de helling geplaatst. ${ }^{34 \mathrm{I}}$ De verbeurdverklaring van artikel 43quater Sw. kan bovendien ook een bestaand causaal verband hypothekeren. Het moet immers worden onderstreept dat deze verbeurdverklaring enkel betrekking heeft op de vermogensvoordelen en geen uitstaans heeft met het misdrijf zelf. Een identiek feit dat niet ten laste werd gelegd, maar waarbij wel het voordeel werd ontnomen krachtens artikel 43quater Sw. kan dus het voorwerp uitmaken van een nieuwe strafzaak voor zover de verjaring van de strafvordering niet is ingetreden. Er zal dan wel niet meer kunnen worden overgegaan tot de verbeurdverklaring van dezelfde vermogensvoordelen.

\subsection{De verbeurdverklaring als beveiligingsmaatregel}

97. Waar er, met uitzondering van de verbeurdverklaring van artikel 43quater Sw., bij de verbeurdverklaring-straf een causaal verband aanwezig moet zijn tussen het bewezen verklaarde misdrijf en het betrokken goed, is dit evenwel niet noodzakelijk bij de verbeurdverklaring als beveiligingsmaatregel. Deze verbeurdverklaring is verplicht zélfs wanneer de beklaagde of de beschuldigde wordt vrijgesproken of overleden is, wanneer de verjaring van de strafvordering is ingetreden of wanneer amnestie werd verleend. De verbeurdverklaring zal bovendien ook moeten worden uitgesproken wanneer het goed zich inmiddels in handen van een derde zou bevinden of wanneer de veroordeelde geen eigenaar is. ${ }^{342}$ Bij de verbeurdverklaring als beveiligingsmaatregel kan men m.a.w. stellen dat eens de causaliteit wordt vastgesteld tussen het betrokken goed en het misdrijf deze niet meer kan wankelen en dit ongeacht het lot van de strafrechtelijke procedure. Een voorbehoud moest tot voor kort worden gemaakt bij de bestraffingsmodaliteit van de opschorting van de

340 Krachtens art. 43quater $\$ 3$ lid 3 Sw. zijn identieke feiten de feiten die behoren tot de misdrijfomschrijvingen die zijn bepaald in $\S$ I en die vallen onder: a) ofwel dezelfde omschrijving als het misdrijf dat het voorwerp uitmaakt van de veroordeling; b) ofwel een aanverwante omschrijving, op voorwaarde dat deze is opgenomen onder dezelfde rubriek van $\S \mathrm{I}$, a), als het misdrijf dat het voorwerp uitmaakt van de veroordeling.

34I Het uitgangspunt is nochtans altijd geweest dat de zaken die enkel verband houden met een misdrijf waarvoor het Openbaar Ministerie geen vervolging heeft ingesteld, buiten boord vallen (A. DE GEEST, Verbeurdverklaring, in APR, Brussel, Larcier, I97I, 62 die verwijst naar Cass. II februari I907, Pas. I907, I, II9; Cass. 9 mei I939, Pas. I939, I, 23I; Cass. 8 januari I95I, Pas. I95I, I, 279).

342 Pandectes belges, $v^{\circ}$ Confiscation, nr. 223. 
uitspraak van de veroordeling waar de verbeurdverklaring krachtens artikel 6 lid 2 Probatiewet ${ }^{343}$ verplicht moest worden voorafgegaan door een schriftelijke vordering van het Openbaar Ministerie ongeacht welke verbeurdverklaring er geviseerd wordt. Bovendien krijgt de verbeurdverklaring in alle gevallen een facultatief karakter. ${ }^{344}$ De letterlijke lezing van artikel 6 lid 2 Probatiewet ('De bijzondere verbeurdverklaring kan op schriftelijke vordering van het Openbaar Ministerie worden uitgesproken') strookte niet met de ratio legis en kan leiden tot aberrante situaties. Niettemin leek de jurisprudentie uit te gaan van de primauteit van een duidelijke strafbaarstelling waardoor de ratio legis moest wijken voor de heldere bewoordingen van een wettekst. ${ }^{345}$ Artikel 5 I van de wet van II februari 20I4 houdende diverse maatregelen ter verbetering van de invordering van de vermogensstraffen en de gerechtskosten in strafzaken (I) ${ }^{34^{6}}$ heeft artikel 6 Probatiewet echter in die zin gewijzigd dat er van een verplichte vordering niet langer sprake is en dat er geen afbreuk meer wordt gedaan aan de verplichte vormen van verbeurdverklaring. ${ }^{347}$

\section{Correctiemechanismen bij verbeurdverklaring ondanks causaliteit}

98. Het uitgangspunt is dat de verbeurdverklaring op ogenblikkelijke en onherroepelijke wijze het eigendomsrecht van de veroordeelde op de besmette goederen tenietdoet en dat de door de wet geviseerde goederen een ruim werkingsveld bestrijken. De strafrechter kan nochtans in een verbeurdverklaringscenario geen nattevingerwerk verrichten en is gebonden door een aantal principes zélfs wanneer het causaal verband tussen het betrokken goed en het misdrijf onomwonden vaststaat. De gehanteerde equivalentietheorie (die toch de meeste vormen van verbeurdverklaring typeert) zal m.a.w. moeten worden bijgeschaafd ten behoeve van de autonomie van het strafrecht, meer bepaald ten gevolge van bepaalde aan de verbeurdverklaring gerelateerde voorwaarden.

Zo dient er in de eerste plaats rekening te worden gehouden met begrenzingen aangebracht door de wetgever. Het kan niet genoeg worden benadrukt dat straffen in de eerste plaats wettelijk moeten zijn. Dit volgt uit het legaliteitsprincipe dat tot uitdrukking komt in het adagium 'Nulla poena sine lege'. Enkel die zaken mogen dus worden verbeurdverklaard waar de wetgever expliciet in heeft voorzien zelfs wanneer men een causaal verband meent te kunnen ontwaren tussen het goed en het misdrijf. Nochtans stelt men vast dat er - weliswaar in uitzonderlijke gevallen - afbreuk

343 Wet 29 juni 1964 betreffende de opschorting, het uitstel en de probatie, BS I7 juli ig64.

344 Antwerpen 2I mei 2008, NC 2008, 366, noot J. ROZIE, 'De verbeurdverklaring bij opschorting van de uitspraak van de veroordeling: openbaar ministerie wees waakzaam!'.

345 J. ROZIE, 'Beklaagde Alwetend. Over het criterium van de redelijke voorzienbaarheid als maatstaf van het lex certa-principe in strafzaken', RW 20I2-20I3, 8I4.

346 BS 8 april 2014.

347 Het nieuwe artikel 6 lid 2 Probatiewet luidt thans als volgt: 'Wordt de opschorting gelast, dan wordt de verdachte, de inverdenkinggestelde of de beklaagde veroordeeld in de kosten, en zo daartoe aanleiding bestaat, tot de teruggave. Het onderzoeks- of vonnisgerecht kan of moet de verdachte, de inverdenkinggestelde of de beklaagde veroordelen tot bijzondere verbeurdverklaring overeenkomstig de op de feiten toepasselijke wetgeving.' 
wordt gedaan aan het wettelijk karakter van de verbeurdverklaring. Te denken valt aan de nochtans door het Hof van Cassatie en het Grondwettelijk Hof aanvaarde praktijk in het douanestrafrecht die de strafrechter toelaat om zonder wettekst naast de verbeurdverklaring krachtens artikel 22I § I AWDA de beklaagde eveneens te veroordelen tot de betaling van de tegenwaarde van de verbeurdverklaarde goederen bij niet-overlegging ervan..$^{348}$ Deze gang van zaken komt de facto neer op een vorm van verbeurdverklaring bij equivalent. Betrokken goederen vormen nochtans geen surrogaat van het oorspronkelijke goed. Causaliteit lijkt bovendien hier ver zoek te zijn nu de oorspronkelijke goederen nog perfect verbeurdverklaard kunnen worden aangezien het mechanisme in werking treedt ongeacht of het object nog voorhanden is of niet op het ogenblik van de uitspraak, i.t.t. de waardeconfiscatie van artikel 43 bis lid 2 Sw. die maar enkel openstaat wanneer de oorspronkelijke illegale vermogensvoordelen werden opgesoupeerd.

Sommige begrenzingen hebben mogelijk een weerslag op het lot van de verbeurdverklaring hoewel het causaal verband wél kan worden aangetoond. Te denken valt aan het gegeven dat bepaalde verbeurdverklaringen (zoals de voordeelsontneming) een facultatief karakter hebben en er soms een eigendomsvoorwaarde geldt (zoals bij de verbeurdverklaring van het voorwerp van het misdrijf en van de instrumenten van het misdrijf). Ook geldt soms de premisse van een voorafgaande schriftelijke vordering van het Openbaar Ministerie (cf. art. 43bis Sw.). Ten slotte moeten er motiveringsvereisten worden nageleefd bij gebreke waaraan een uitgesproken verbeurdverklaring onwettig zal zijn.

Andere begrenzingen hebben te maken met het gegeven dat er steeds een rechtvaardige verbeurdverklaring moet worden nagestreefd. Dit impliceert dat er niet mag worden geflirt met het grondwettelijk verbod op algemene confiscatie, de sanctie niet onevenredig mag zijn met het nagestreefde doel, eenzelfde goed maar eenmaal kan worden verbeurdverklaard en eigendomsaanspraken van de bonafide derde hoog in het vaandel dienen te worden gedragen. ${ }^{349}$

Het dient te worden benadrukt dat beide types van begrenzingen aan de causaliteit raakpunten kunnen hebben en zelfs kunnen overlappen. Zo kunnen de voorgeschreven motiveringsvereisten uiteraard verhinderen dat er een willekeurige verbeurdverklaring wordt uitgesproken. Recentelijk werd trouwens in artikel 43 bis Sw. een veralgemeende matigingsbevoegdheid van de rechter opgenomen op grond waarvan de rechter het bedrag van de in artikel 42 lid 3 Sw. bedoelde vermogensvoordelen of van het overeenstemmend equivalent bedrag vermindert teneinde de

348 A. DE NAUW, 'Een wettelijke straf zonder wettelijke basis. De veroordeling tot de betaling van de tegenwaarde van de verbeurd verklaarde goederen bij niet-overlegging ervan in douane en accijnzen', NC 20I3, 48-53 (noot onder GwH I december 20II, nr. I8I/20II); P. WAETERINCKX, 'Twee recente ontwikkelingen van belang voor het ondernemingsstrafrecht', in Strafrecht in breed spectrum, Brugge, die Keure, 20I4, nrs. I-43, ter perse; P. WAETERINCKX, 'Juridische "creativiteit" ten dienste van de " kaalpluk" bij accijns- en douanefraude', NC 20I4, 320 (noot onder Cass. 29 april 20I4).

349 Zie in dit verband ook J. ROZIE, 'Koorddansen tussen eerbiediging van het recht op eigendom en een rechtvaardige verbeurdverklaring', in S. DEWULF en D. PACQUÉE (eds.), 6o jaar Universele Verklaring van de Rechten van de Mens 1948-2008, Antwerpen, Intersentia, 2008, I33-156. 
veroordeelde geen onredelijke straf op te leggen..$^{350}$ Sommigen bepleiten ook met verdienstelijke argumenten, en dit ondanks causaliteit tussen het besmette goed en het misdrijf, een facultatief karakter van de verbeurdverklaring en hekelen daarbij het recent ingevoerd verbod van uitstel van de tenuitvoerlegging m.b.t. de bijzondere verbeurdverklaring ${ }^{351}$ met als achterliggende reden dat enkel op die manier in bepaalde gevallen een meer rechtvaardige verbeurdverklaring kan worden bewerkstelligd. ${ }^{352}$ Anderen schermen met het principe dat criminaliteit in geen enkel opzicht zou mogen lonen en houden daarom vast aan een verplicht karakter van de verbeurdverklaring en dit voor alle types verbeurdverklaring van zodra het causaal verband vaststaat en vinden dat de bestraffingsmodaliteit van het uitstel van de tenuitvoerlegging van de straf niet rijmt met de essentie van de verbeurdverklaring. ${ }^{353}$ Dit neemt niet weg dat in bepaalde strafzaken, te denken valt aan witwaszaken waar er een verplichte verbeurdverklaring wordt vooropgesteld van de witgewassen vermogensvoordelen telkenmale er sprake is van een strafbare witwashandeling, een verplichte verbeurdverklaring zonder mogelijkheid tot uitstel tot disproportionele ongewenste resultaten kan leiden. Dit laatste geldt zeker in die gevallen waar de causaliteitsketen lijkt te wankelen omwille van het gegeven dat de witwasser slechts als doorgeefluik kan worden aangemerkt. In die gevallen zou men dan moeten kunnen schermen met artikel I van het Eerste Aanvullend Protocol bij het EVRM (dat het recht op eigendom waarborgt).

Het valt buiten het bestek van deze bijdrage, maar het dient toch te worden aangestipt dat het misdrijf witwassen ook vanuit een ander causaliteitsperspectief kopzorgen kan opleveren. De rechtspraak ${ }^{354}$ is immers in die zin gevestigd dat het basismisdrijf dat ten grondslag ligt aan het witwasmisdrijf niet moet worden geïdentificeerd waardoor het in bepaalde gevallen moeilijk lijkt te zijn de illegale oorsprong of m.a.w. het causaal verband hard te maken. Er wordt weliswaar vooropgesteld dat op grond van feitelijke gegevens elke legale herkomst of oorsprong kan worden uitgesloten, toch moet worden vastgesteld dat deze negatief geformuleerde zekerheid, geregeld tot laksheid leidt m.b.t. de motivering van het basismisdrijf. 355 Als de strafrechter bovendien niet exact kan bepalen welke vermogensvoordelen

350 Zie art. 55 van de wet van II februari 2014 houdende diverse maatregelen ter verbetering van de invordering van de vermogensstraffen en de gerechtskosten in strafzaken, BS 8 april 2014 .

35I Zie art. 52 van de wet van II februari 2014 houdende diverse maatregelen ter verbetering van de invordering van de vermogensstraffen en de gerechtskosten in strafzaken, BS 8 april 2014 .

352 P. WAETERINCKX, “Koterijbouw” op het erf van de voordeelsontneming. De voordeelsontneming met uitstel afgeschaft sinds I8 april 20I4', in J. ROZIE, F. DERUYCK, L. HUYBRECHTS en F. VAN VOLSEM (eds.), Na rijp beraad. Liber amicorum Michel Rozie, Antwerpen, Intersentia, 20I4, ter perse; Zie ook P. WAETERINCKX, 'Het onroerend goed als vermogensvoordeel', in J. ROZIE (ed.), Het onroerend goed in het straf(proces)recht, Antwerpen, Intersentia, 20I2, 92-95.

353 J. ROZIE, 'De bijzondere verbeurdverklaring opgewaardeerd', in F. DERUYCK, E. GOETHALS, L.HUYBRECHTS, J.-F. LECLERCQ, J. ROZIE, M. ROZIE, P. TRAEST en R. VERSTRAETEN (eds.), Amicus Curiae. Liber amicorum Marc De Swaef, Antwerpen, Intersentia, 2013, 297-298 en 303-305.

354 Zie o.m. Cass. 2I juni 2000, Arr.Cass. 2000, II65; Cass. 25 september 200I, Arr.Cass. 200I, I536; Cass. 9 mei 2006, Arr.Cass. 2006, Io6r; Cass. 28 november 2006, Arr.Cass. 2006, 244I; Cass. I9 september 2006, NC 2007, 2I5, noot E. VAN DOOREN; Cass. 3 april 20I2, NC 2013, 243, noot P. WAETERINCKX en H. HUYSMANS.

355 P. WAETERINCKX, 'De verwatering van het basismisdrijf', in A. DE NAUW (ed.), De groeipijnen van het strafrecht, Brugge, Die Keure, 2007, 44. 
er werden witgewassen, kan hij ook niet nagaan voor welke illegale vermogensvoordelen elke legale oorsprong kan worden uitgesloten. De causaliteitspremisse indachtig, lijkt het dan ook moeilijk verdedigbaar dat het beweerd witwassen van een niet correct en objectief vermogensvoordeel een bewezen witwasmisdrijf kan omvatten. ${ }^{356}$

\section{Besluit}

99. De causaliteitsproblematiek lijkt in het strafrecht van minder belang te zijn of althans stiefmoederlijker te worden behandeld dan in het buitencontractueel aansprakelijkheidsrecht. ${ }^{357}$ Het klopt dat de strafrechtelijke rechtsleer duidelijk minder aandacht aan het causaliteitsvereiste besteedt dan de civielrechtelijke tegenhanger. Meer dan eens wordt voor een uiteenzetting over het causaal verband verwezen naar civielrechtelijke rechtsliteratuur. Daarbij kan een rol spelen dat het causaal verband tussen de fout of een bepaalde factor en de schade noodzakelijk is voor elke civielrechtelijke aansprakelijkheid. In het strafrecht daarentegen speelt het causaal verband voor bepaalde misdrijven, zoals de gedragsmisdrijven, geen enkele rol. Dit weerspiegelt zich ook in de verschillende functies van beide rechtstakken: waar het strafrecht zich focust op maatschappelijk verwerpelijke gedragingen, beoogt het buitencontractueel aansprakelijkheidsrecht eerder schade te vergoeden. Toch kan die mindere aandacht verbazen. Ook in het strafrecht speelt het causaal verband een belangrijke rol en zoals gezegd zelfs op drie niveaus (misdrijf-, dader- en sanctieniveau).

Uit onze analyse blijkt dat de rechtspraak doorgaans trouw is en blijft aan de equivalentieleer. Toch is de equivalentietheorie voornamelijk in de strafrechtelijke sfeer niet onomstreden. Er zijn zowel voor-als tegenstanders.

De tegenstanders verwijzen in hun kritiek naar de onbillijke gevolgen van deze leer, nu iemand aansprakelijk wordt gesteld voor de abnormale gevolgen van bepaald gedrag. Weliswaar wordt daarbij meteen opgemerkt dat het conditio sine qua non-verband tussen het gedrag en een bepaald gevolg slechts slaat op het objectieve bestanddeel van het misdrijf. De overdreven gevolgen van de equivalentietheorie kunnen worden beperkt door andere eisen waaraan het misdrijf moet voldoen, zoals de aanwezigheid van de wederrechtelijkheid en het moreel bestanddeel..$^{35}$

356 P. WAETERINCKX en H. HUYSMANS, 'De illegale oorsprong van het vermogensvoordeel dat men witwast. Hoe onbepaald mag de omvang ervan zijn?’, NC 2013, 248-249.

357 In die zin ook voor het Franse recht: P.-A. BON, La causalité en droit pénal, Collection de la faculté de Droit et des Sciences sociales de Poitiers, 2006, nr. 34.

358 Zie ook L. DUPONT en R. VERSTRAETEN, Handboek Belgisch Strafrecht, Acco, Leuven, I990, I95; R. VERSTRAETEN en F. VERBRUGGEN, Strafrecht en strafprocesrecht voor bachelors, Deel I, Antwerpen, Maklu, 20I3, nr. I6I. 
Sommige auteurs gaan zelfs zo ver te stellen dat het vereiste van een causaal verband in het strafrecht enkel kan verwijzen naar de adequatieleer. Daarbij zou alleen moeten onderzocht worden of het gedrag van de beklaagde de enige of determinerende oorzaak, 359 dan wel de adequate of voorzienbare oorzaak ${ }^{360}$ was van het door de wet verboden resultaat. De equivalentietheorie zou strijdig zijn met de groeiende subjectivering van het strafrecht en zou eerder thuishoren in het buitencontractueel aansprakelijkheidsrecht, maar niet in het strafrecht. ${ }^{36 \mathrm{I}}$ In dezelfde lijn verkondigt een deel van de rechtsleer dat het gebrek aan voorzorg de directe oorzaak moet zijn geweest van het gevolg (bv. het overlijden). Zo zou het causaal verband tussen een fout en de schade door een tussenkomende oorzaak van een derde worden doorbroken, wanneer de uiteindelijke schade onvoorzienbaar is en afwijkt van de normale gang van zaken die uit zo'n fout voortvloeit. ${ }^{362}$ Bijgevolg, zo wordt gesteld, is er geen causaal verband tussen de aanranding met het oogmerk te doden en de dood, wanneer de toegebrachte letsels niet dodelijk waren, maar nadien door een andere, onafhankelijke en tussenkomende oorzaak, bv. verkeerde behandeling door een arts, toch een dodelijke afloop kennen..$^{363}$ Sommige auteurs stellen daarom voor de equivalentietheorie te verlaten en in te ruilen voor een van de andere besproken theorieën, zoals de adequatietheorie, ${ }^{364}$ de theorie van de efficiënte oorzaak ${ }^{365}$ of een variante op de theorie van de toerekening naar redelijkheid. ${ }^{366}$

Een ander deel van de rechtsleer meent dat de rechtszekerheid in het gedrang komt en dat de wetgever wettelijke criteria zou moeten invoeren die een controle van het Hof van Cassatie op de feitenrechter mogelijk zou moeten maken. ${ }^{367}$ Weliswaar leert de Nederlandse ervaring dat het opnemen van een causaliteitsleer met criteria in

359 F. KUTY, Principes généraux du droit pénal belge. Tome II: l'infration pénale, Brussel, Larcier, 20ro, 8I en 86.

360 N. COLETTE-BASECQZ en N. BLAISE, 'Responsablité civile et responsabilité pénale', Responsabilité. Traité théorique et pratique, Partie préliminaire, Livre 2, Waterloo, Kluwer, 20I2, p. 80, nr. I26.

36I F. KUTY, Principes généraux du droit pénal belge. Tome II: l'infration pénale, Brussel, Larcier, 2010, 8I en 86; zie ook A. DELANNAY, 'Les homicides et lésions corporelles volontaires', Les infractions. Volume 2. Les infractions contre les personnes, Brussel, Larcier, 20IO, I55.

362 C. HENNAU, J. VERHAEGEN, D. SPIELMAN en A. BRUYNDONCKX, Droit pénal général, Brussel, Bruylant, 2003, nr. 176.

363 P. ARNOU, 'Opzettelijk doden en het opzettelijk toebrengen van lichamelijk letsel', in Bijzonder strafrecht voor rechtspractici, Leuven, Acco, I990, 49.

364 D. PHILIPPE, 'À propos du lien causal' (noot onder Cass. I4 juni I996), JLMB I997, $283 ;$ M. ADAMS, 'Over de zwaartekrachtwerking van rechterlijke uitspraken in België', TPR I997, I380; N. COLETTE-BASECQZ en N. BLAISE, 'Responsablité civile et responsabilité pénale', Responsabilité. Traitéthéorique et pratique, Partie préliminaire, Livre 2, Waterloo, Kluwer, 2012, 80, nr. I29; zie ook F. VAN VOLSEM, 'Culpa in het Belgisch strafrecht: een poging tot synthese', in Preadviezen 2012. Vereniging voor de vergelijkende studie van het recht van Belgiëen Nederland, Den Haag, Boom Juridische uitgevers, 20I2, I29.

365 M. ADAMS, 'Over de zwaartekrachtwerking van rechterlijke uitspraken in België', TPR I997, I380.

366 I. DURANT, 'La causalité, simple trait d'union ou veritable variable d'ajustement', in P. WÉRY (ed.), Droit des obligations: développements récents et pistes nouvelles, CUP volume 96, Louvain-laNeuve, Anthémis, 2007, 7I-8I.

367 C. VAN DEN WYNGAERT, m.m.v. B. DE SMET en S. VANDROMME, Strafrecht en strafprocesrecht in hoofdlijnen, Antwerpen, Maklu, 20II, 301. 
de wetgeving, niet uitsluit dat ook dan er onzekerheid kan blijven bestaan over de uitspraak in bepaalde casussen.

De conclusie om al dan niet via wetgeving over te stappen naar een andere causaliteitsleer, is te verregaand en daaraan is o.i. geen behoefte. ${ }^{368} \mathrm{Wij}$ pleiten voor het behoud van de equivalentietheorie, nu het een slachtoffervriendelijke leer is die spoort met de vergoedende functie van het aansprakelijkheidsrecht ${ }^{369}$ en het strafrecht. Ook voor de verdachte zijn er voldoende waarborgen. Het lijkt bovendien ook eenvoudiger en efficiënter dat in verschillende rechtstakken een gebruikt begrip als het causaal verband op dezelfde wijze wordt ingevuld en geïnterpreteerd. Eenzelfde rechter, de strafrechter, kan zo op basis van dezelfde criteria zowel over de strafvordering als over de burgerlijke vordering oordelen. ${ }^{370}$

Een zuivere toepassing van de equivalentieleer ligt in sommige situaties moeilijk, zoals zeker uit het subhoofdstuk van de gevolgmisdrijven is gebleken. Verder kunnen ook andere factoren, zoals de rechtvaardigheid, een rol spelen in de discussie of iets als een oorzaak moet worden beschouwd. Dit heeft tot gevolg dat in heel wat landen officieel een welbepaalde causaliteitstheorie wordt gehuldigd, maar dat in werkelijkheid dit niet steeds consequent gebeurt en er heel wat uitzonderingen worden toegestaan. ${ }^{37 \mathrm{~T}}$ Ook in België moeten er dus in bepaalde omstandigheden uitzonderingen worden aanvaard. Dit is niet zo erg, nu in de meeste causaliteitstheorieën uitzonderingen voor specifieke situaties worden aanvaard. Van een theorie hoeft niet te worden verwacht dat alle mogelijke probleemsituaties eronder zouden vallen. De kritiek op de huidige rechtspraak bestaat erin dat meestal geen lijn valt te trekken in de verschillende uitzonderingen. Van het Hof van Cassatie kan verwacht worden dat de uitzonderingen meer gemotiveerd zouden worden. Meer in het algemeen zou er een theoretisch kader moeten worden uitgewerkt waarin die uitzonderingen, vooral voor onrechtstreekse oorzaken, hun plaats vinden.

Na onze analyse blijkt de equivalentietheorie echter ook in het strafrecht te zegevieren en dit niet alleen op het niveau van het misdrijf, maar ook op dat van de dader en van de sanctie. Dit neemt niet weg dat bijsturingen moeten kunnen plaatsvinden ten behoeve van de autonomie van het strafrecht. Dit is het geval bij de leer van de strafbare poging waar er eerder van een virtueel causaal verband kan worden gesproken. Ook in het raam van de strafbare deelneming dienen er correcties te worden aangebracht en moet bv. de individualisering van de bestraffing hoog in het vaandel worden gedragen en moet een specifieke regeling worden uitgewerkt m.b.t. de al dan niet doorwerking van de objectieve verzwarende omstandigheden.

368 B. WEYTS, 'Blijft het Hof van Cassatie trouw aan de equivalentieleer bij een samenloop van fouten?' (noot onder Cass. 22 april 2004), RW 2004-05, 830.

369 H. BOCKEN, 'Toerekening van aansprakelijkheid op grond van de equivalentieleer', in Buitencontractuele aansprakelijkheid, Reeks Recht en onderneming, Brugge, die Keure, 2004, 244.

370 F. VAN VOLSEM, 'Culpa in het Belgisch strafrecht: een poging tot synthese', in Preadviezen 2012. Vereniging voor de vergelijkende studie van het recht van België en Nederland, Den Haag, Boom Juridische uitgevers, 2012, $137-138$.

37 I A.M. HONORE, 'Causation and remoteness of damage', Torts, volume XI, International encyclopedia of comparative law, Tubingen, Mohr, $\mathrm{I}_{983}, 3$, nr. I. 
De specifieke situatie van de geestesgestoorde delinquent vereist eveneens dat de equivalentietheorie moet worden verlaten wanneer de geestesstoornis zich enkel manifesteert op het ogenblik van de berechting en niet op het ogenblik van het plegen van het misdrijf. In deze hypothese komt het causaal verband zelfs niet aan de orde, nu er in de vooropgestelde hypothese per definitie geen link is tussen de geestesstoornis en het gepleegde misdrijf. Op sanctieniveau heeft de analyse van de rechtsfiguur van de bijzondere verbeurdverklaring ons geleerd dat er bepaalde correctiemechanismen in werking treden ondanks causaliteit tussen het betrokken goed en het gepleegde misdrijf. Zo zal men waakzaam moeten zijn dat het grondwettelijk verbod op algemene verbeurdverklaring niet met de voeten wordt getreden, dat de sanctie niet onevenredig is met het nagestreefde doel, dat eenzelfde goed maar eenmaal wordt verbeurdverklaard en dat de eigendomsaanspraken van de bonafide derde worden gerespecteerd.

Bepaalde auteurs vinden het belang van de causaliteitsproblematiek overschat, stellen het gelijk met een leuke hersenoefening, maar menen dat in de grote meerderheid van de zaken het causaliteitsprobleem zich niet voordoet. ${ }^{372}$ Hiermee lijkt het kind wel met het badwater te worden weggegooid. Deze bijdrage heeft duidelijk gemaakt dat de problematiek van het causaal verband door de jaren heen nog niets aan relevantie en complexiteit heeft ingeboet. Meer nog, gelet op de vele rechtspraak die in deze bijdrage werd verzameld, is de indruk dat het causaal verband zowel in het buitencontractueel aansprakelijkheidsrecht als in het strafrecht aan belang wint. Waar niemand het ooit heeft aangedurfd het strafrecht en het buitencontractueel aansprakelijkheidsrecht over dezelfde kam te scheren, heeft de analyse - buiten alle verwachtingen - aangetoond dat het buitencontractueel aansprakelijkheidsrecht en het strafrecht elkaar niet per se hoeven af te stoten, maar integendeel mits correcties ten behoeve van de autonomie van het strafrecht op een harmonieuze manier met elkaar door het leven kunnen gaan.

372 S. DEAKIN, A. JOHNSTON en B. MARKESINIS, Markesinis and Deakin's Tort law, Clarendon Press, 2008, 82: 'In the great majority of negligence cases, the problem does not arise at all (...). So, by all means let us study causation cases (and other topics of particular theoretical import) since they can help sharpen the mind; but let us also remember to keep the problem in perspective; and let us warn our students about it.' 